Gallagher, S.J., Fulthorpe, C.S., Bogus, K., and the Expedition 356 Scientists Proceedings of the International Ocean Discovery Program Volume 356

publications.iodp.org

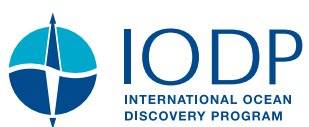

\title{
Contents
}

\section{Expedition 356 summary ${ }^{1}$}

Check for updates

S.J. Gallagher, C.S. Fulthorpe, K. Bogus, G. Auer, S. Baranwal, I.S. Castañeda, B.A. Christensen, D. De Vleeschouwer, D.R. Franco, J. Groeneveld, M. Gurnis, C. Haller, Y. He, J. Henderiks, T. Himmler, T. Ishiwa, H. Iwatani, R.S. Jatiningrum, M.A. Kominz, C.A. Korpanty, E.Y. Lee, E. Levin, B.L. Mamo, H.V. McGregor, C.M. McHugh, B.F. Petrick, D.C. Potts, A. Rastegar Lari, W. Renema, L. Reuning, H. Takayanagi, and W. Zhang ${ }^{2}$

Keywords: International Ocean Discovery Program, IODP, Expedition 356, JOIDES Resolution, Site U1458, Site U1459, Site U1460, Site U1461, Site U1462, Site U1463, Site U1464, northwest shelf of Australia, Indonesian Throughflow, Eocene, Oligocene, Miocene, Pliocene, Pleistocene, Australian monsoon, subsidence, aridity, reefs, ooids, anhydrite, tropical carbonates, subtropical carbonates

\section{Abstract}

The Indonesian Throughflow (ITF) is a critical part of the global thermohaline conveyor. It plays a key role in transporting heat from the equatorial Pacific (the Indo-Pacific Warm Pool) to the Indian Ocean and exerts a major control on global climate. The complex tectonic history of the Indonesian archipelago, a result of continued northward motion and impingement of the Australasian plate into the southeast Asian part of the Eurasian plate, makes it difficult to reconstruct long-term (i.e., million year) ITF history from sites within the archipelago. The best areas to investigate ITF history are downstream in the Indian Ocean, either in the deep ocean away from strong tectonic deformation or along proximal passive margins that are directly under the influence of the ITF. Although previous Ocean Drilling Program and Deep Sea Drilling Project deepwater cores recovered in the Indian Ocean have been used to chart Indo-Pacific Warm Pool influence and, by proxy, ITF variability, these sections lack direct biogeographic and sedimentological evidence of the ITF. International Ocean Discovery Program Expedition 356 cored seven sites covering a latitudinal range of $29^{\circ} \mathrm{S}-18^{\circ} \mathrm{S}$ off the northwest coast of Australia to obtain a 5 My record of the ITF, Indo-Pacific Warm Pool, and climate evolution that has the potential to match orbital-scale deep-sea records in its resolution. The material recovered will allow us to describe the history of the Australian monsoon and its variability, a system whose genesis is thought to be related to the initiation of the East Asian monsoon and is hypothesized to have been in place since the Pliocene or earlier. It also will lead to a better understanding of the nature and timing of the development of aridity on the Australian continent.

Detailed paleobathymetric and stratigraphic data from the transect will also allow subsidence curves to be constructed to con- strain the spatial and temporal patterns of vertical motions caused by the interaction between plate motion and convection within the Earth's mantle, known as dynamic topography. The northwest shelf is an ideal location to study this phenomenon because it is positioned on the fastest moving continent since the Eocene, on the edge of the degree 2 geoid anomaly. Accurate subsidence analyses over $10^{\circ}$ of latitude can resolve whether northern Australia is moving with or over either a time-transient or long-term stationary downwelling within the mantle, thereby vastly improving our understanding of deep-Earth dynamics and their impact on surficial processes.

\section{Introduction}

During the past $5 \mathrm{My}$, Earth's climate has experienced a major transition from mid-Pliocene warmth to Late Pleistocene ice ages (Rohling et al., 2014). Although we now have increasing numbers of high-resolution records of climate variability from ocean basins in both high-latitude and equatorial regions (McClymont et al., 2013), high-resolution information for the northwestern region of Australia and from other shelfal areas worldwide is rare. The wedge of sediment that has accumulated over the last $5 \mathrm{My}$ on the northwest shelf (NWS) of Australia epitomizes the geological history of Australia's northern margin (Figure F1). The section is made up of a variety of sediment types including subtropical to tropical shelf calcarenite, calcilutite, marl, and deep-water calcareous mudstone and siltstone eroded by submarine canyons (Wallace et al., 2003). In combination, these sediments make up a prograding shelf-type system typical of much of the Australian continental margin (Wallace et al., 2002).

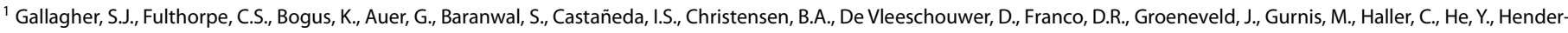
iks, J., Himmler, T., Ishiwa, T., Iwatani, H., Jatiningrum, R.S., Kominz, M.A., Korpanty, C.A., Lee, E.Y., Levin, E., Mamo, B.L., McGregor, H.V., McHugh, C.M., Petrick, B.F., Potts, D.C., Rastegar Lari, A., Renema, W., Reuning, L., Takayanagi, H., and Zhang, W., 2017. Expedition 356 summary. In Gallagher, S.J., Fulthorpe, C.S., Bogus, K., and the Expedition 356 Scientists, Indonesian Throughflow. Proceedings of the International Ocean Discovery Program, 356: College Station, TX (International Ocean Discovery Program). http://dx.doi.org/10.14379/iodp.proc.356.101.2017

2 Expedition 356 Scientists' addresses.

MS 356-101: Published 26 February 2017
} 
Figure F1. Map of the NWS showing major basins and location of modern and "fossil" reefs. Seismic data near Site U1461 is shown in Figure F8. Stars = drill sites, green circles = Deep Sea Drilling Project (DSDP)/Ocean Drilling Program (ODP) sites and other core locations referred to in text, yellow circles $=$ industry well locations (Angel = Angel-1; G2/6/7 = Goodwyn-2, Goodwyn-6, Goodwyn-7; A1 = Austin-1; M/MN1 = Maitland/Maitland North-1;TR1 $=$ West Tryal Rocks-1). WA $=$ Western Australia, NT $=$ Northern Territory, SA = South Australia, QLD = Queensland, NSW = New South Wales.

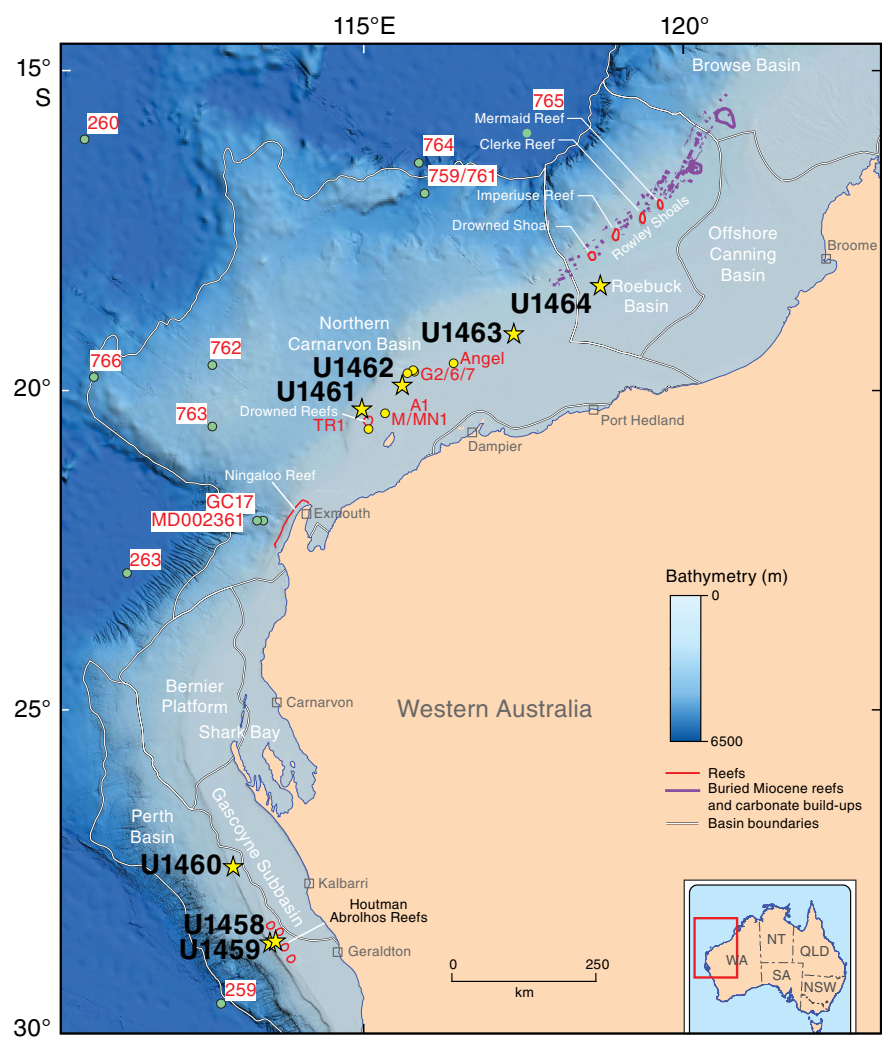

The foci of International Ocean Discovery Program (IODP) Expedition 356 fell under the following three main headings.

\section{Indonesian Throughflow, Leeuwin Current, and reef development}

During the late Neogene, the NWS has acted as a subsiding platform upon which most contemporary environmental changes are recorded. Located at the fringes of the Indo-Pacific Warm Pool, this margin is therefore an ideal region in which to study tropical oceanography (Rosleff-Soerensen et al., 2012) and the history of the Indonesian Throughflow (ITF). The ITF also helps drive the Leeuwin Current, which is the only southward-flowing eastern boundary current in the Southern Hemisphere (Cresswell, 1991; Pearce, 2009). This current extended tropical reef development to $29^{\circ} \mathrm{S}$ during the Late Pleistocene (Collins et al., 2006). The orbital-scale variability of the Leeuwin Current can be estimated using tropical sedimentary (coral reefs and ooids) and fossil biogeographic indexes (Gallagher et al., 2009, 2014b, 2015), so we can determine by proxy the underlying controls that triggered Pliocene-Pleistocene reef development. Coring a latitudinal transect from $29^{\circ} \mathrm{S}$ to $18^{\circ} \mathrm{S}$ provides essential information as to whether the switch to tropical sedimentation was synchronous or diachronous in this region as well as a long-term perspective on how coral reefs in the east Indian Ocean developed through variable climatic conditions.

\section{Australian monsoon and continental aridity}

The continental shelf in this region lies directly offshore the semi-arid Australian continent climatically dominated by the Australian monsoon (Suppiah, 1992). Shelf/slope sediments therefore host a vast but barely explored archive of late Neogene climate variability (van der Kaars and De Deckker, 2002). Expedition 356 results will increase our understanding of the long-term geographic controls on Australian monsoonal variability and its relationship to the onset of aridity in Australia (McLaren et al., 2014).

\section{Subsidence and geodynamics of the Australian plate}

Obtaining high-resolution stratigraphic data from the NWS will lead to improved burial and subsidence estimates for this region. These data will enable us to decipher the contribution of large-scale geodynamic processes, such as dynamic topography, on the vertical motions of the Earth's surface and associated effects on the NWS sedimentary system (Czarnota et al., 2013).

\section{Background Tectonic setting}

The NWS is a rifted margin that has existed since late Paleozoic time, when Australia was part of eastern Gondwana (Etheridge and O’Brien 1994; Exon and Colwell, 1994; Longley et al., 2002). Ribbon-like microcontinents separated from this part of the margin in multiple rifting events, with the latest phase of rifting occurring in the Late Jurassic (Heine and Müller, 2005; Exon and Colwell, 1994; Metcalfe, 1988).

IODP Sites U1458-U1460 are in the northern part of the Perth Basin (Figure F1). The remaining sites (U1461-U1464) lie in the Northern Carnarvon Basin (NCB) and Roebuck Basin on the NWS proper with an $8 \mathrm{~km}$ minimum stratigraphic thickness (Longley et al., 2002; Goncharov, 2004). Here, the earliest rifting occurred during the late Permian (initial breakup of eastern Gondwana; Sengor, 1987). Subsequent rifting episodes occurred during the Late Triassic-Early Jurassic and Late Jurassic (von Rad, Haq, et al., 1992; Driscoll and Karner, 1998) with the final rifting in the latest Jurassic also culminating in earliest Cretaceous separation of greater India from Australia (Boote and Kirk, 1989; von Rad, Haq, et al., 1992; Heine and Müller, 2005). The postrift thermal subsidence history of the margin has been affected by mild shortening, generally attributed to plate boundary forces resulting from plate reorganization (Romine et al., 1997; Driscoll and Karner, 1998; Sayers et al., 2001; Cathro et al., 2003; Dyksterhuis et al., 2005). The most recent major nearby tectonic event was the late Miocene collision between northern Australia and the Banda arc (Audley-Charles et al., 1988; Lee and Lawver, 1995; Richardson and Blundell, 1996). Although occurring several hundred kilometers to the north of the drilling area, intraplate stresses associated with this ongoing collision have resulted in localized reactivation and inversion of extensional faults in the NCB (Malcolm et al., 1991; Struckmeyer et al., 1998; Cathro et al., 2003).

\section{Dynamic topographic setting}

Since the breakup and dispersal of eastern Gondwana during the Cretaceous, the Australian plate has moved several thousand kilometers northward (Figure F2) and recorded anomalous flooding patterns that cannot be reconciled with known eustatic variations 
Figure F2. Plate tectonic motion shown for Australia and its margins since 50 $\mathrm{Ma}$ in 10 My intervals, including the path line for Site U1459. Gray = presentday exposed continents, light gray = submerged continental fragments and passive margins, black stars = present-day location of Sites U1459-U1464. Generated with GPlates (http://www.gplates.org) using rotations in Seton et al. (2012).

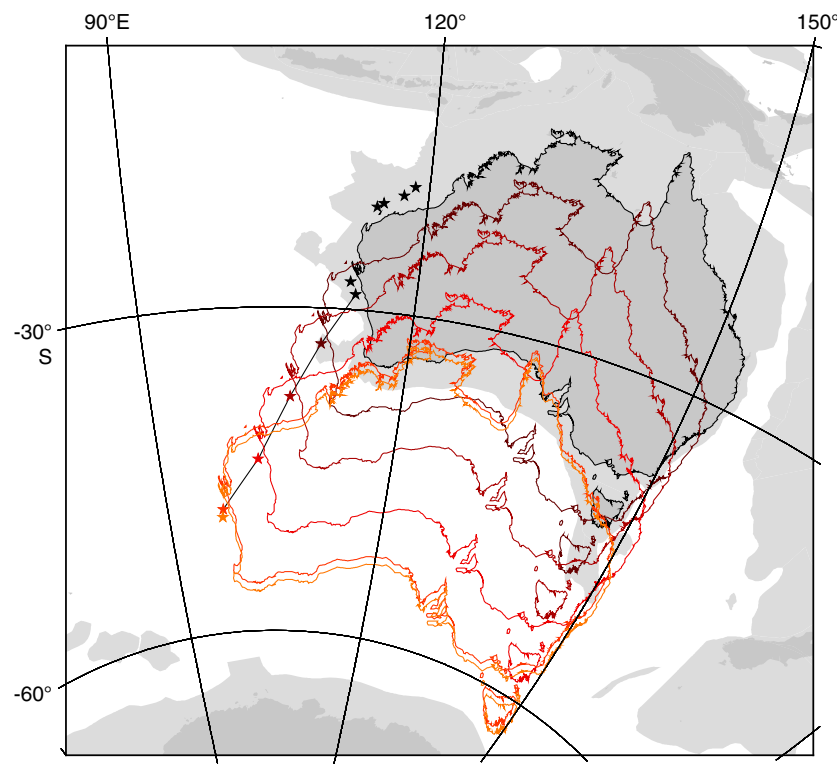

Figure F3. Global sea level (eustatic) curves and inundation history of the Australian continent based on paleoshorelines (Isern et al., 1995). Green = filtered global sea level curve (Haq and Al-Qahtani, 2005), black = global sea level curve (Haq et al., 1987), light blue = filtered curve (Haq et al., 1987), dark blue $=$ Miller et al. (2005) sea level curve, red = Kominz et al. (2008) sea level curve. Filtered lines show the long-wavelength component of the eustatic estimate using a cosine arc filter with a $10 \mathrm{My}$ window. All curves are plotted using the Gradstein et al. (2012) timescale. The amount of inundation (red line with circles) is computed relative to the present-day $200 \mathrm{~m}$ isobath from the ETOPO2 global 2' topography (NOAA, National Geophysical Data Center, 2006). Adapted from Heine et al. (2010).

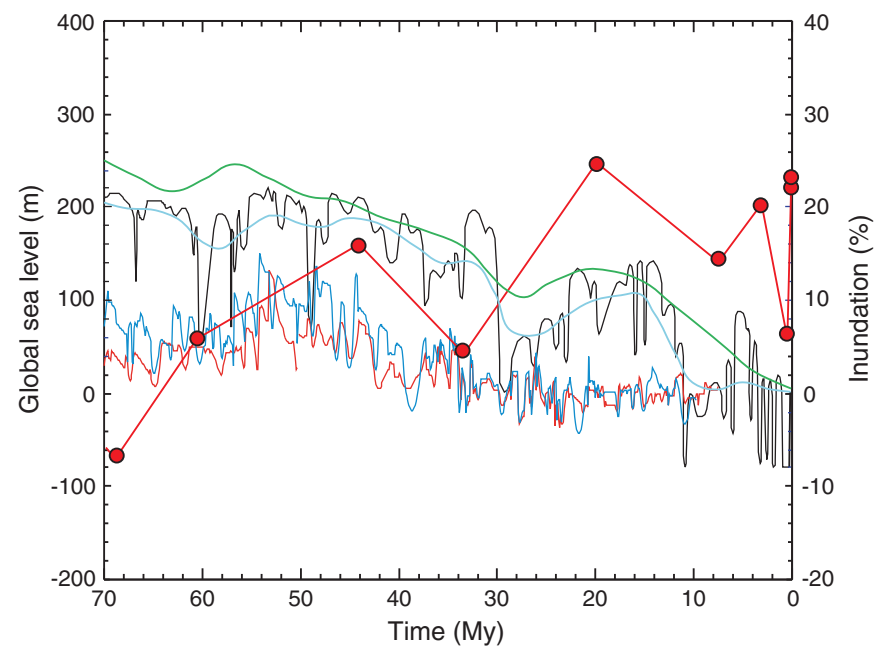

(Figure F3) (Russell and Gurnis 1994; Gurnis et al., 1998; Veevers, 2000; DiCaprio et al., 2009; Heine et al., 2010). Lateral displacements of continents relative to mantle convection patterns have significant impact on the flooding history of continental platforms and margins (Sleep, 1976; Gurnis, 1990, 1993; Russell and Gurnis, 1994).
Eustatic curves constructed from data from a single margin are known to misrepresent actual global sea levels because of the influence of dynamic topography (Müller et al., 2008b; Spasojević et al., 2008; Moucha et al., 2008). Apart from these continental-scale observations, measurements of the amplitude, wavelength, and rate of dynamic topography resulting from circulation within the convecting mantle are rare. Subsidence anomalies along the NWS are ideal targets for the investigation of dynamic topography because the region lies across the gradient of the degree 2 geoid anomaly and on the fastest moving continent since the Eocene (about >35 Ma). These subsidence anomalies have long been known (Müller et al., 2000; Kennard et al., 2003) and can be ascribed to dynamic topography because both thermal subsidence and flexural effects are minimal (Czarnota et al., 2013).

Advancements in computer modeling (DiCaprio et al., 2011) have attributed subsidence anomalies along the NWS to dynamic drawdown of the Earth's surface driven by Australia's rapid northward motion over a generally stationary accumulation of subducted slabs within the mantle beneath southeast Asia (e.g., Lithgow-Bertelloni and Gurnis, 1997; Heine et al., 2010). These models predict that the NWS should be affected by a southward-propagating wave of subsidence related to Australia's northward motion over this stationary cold and dense mantle anomaly. Because Australia's northward motion is $\sim 70 \mathrm{~km} / \mathrm{My}$ and the drilled sites span $10^{\circ}$ of latitude, this model predicts a resolvable subsidence diachroneity of $>10 \mathrm{My}$ between the northernmost and southernmost sites.

In contrast to the diachronous results suggested by geodynamic modeling, recent backstripping of NWS clinoform rollover positions indicates that margin-wide anomalous subsidence was instead broadly synchronous and commenced at $\sim 10 \mathrm{Ma}$ with a down-tothe-north gradient equal in amplitude to adjacent oceanic floor residual depth anomalies (Czarnota et al., 2013). These data suggest that the mantle anomaly responsible for this subsidence may be transient and coupled to the plate motion. However, there is a lack of temporal resolution between 0 and $5 \mathrm{Ma}$ because there are no well-defined clinoform rollovers.

\section{Oceanographic and paleoceanographic setting}

The Indo-Pacific Warm Pool is a region of warm surface waters (average temperature $=28^{\circ} \mathrm{C}$ ) that covers most of the tropical western Pacific and eastern Indian Oceans (Figure F4). The Indo-Pacific Warm Pool plays a major role in heat transport from low to high latitudes and is subject to decadal-scale variability due to the El Niño Southern Oscillation (de Garidel-Thoron et al., 2005). The intensity of the Indo-Pacific Warm Pool functions as a switch in the climate system, and it is consequently a key influence on long- and short-term global climate change (Xu et al., 2006). Therefore, the history of the Indo-Pacific Warm Pool is crucial to our understanding of the global climatic and oceanic systems, as well as their regional effects on the NWS.

Climatic cooling since $15 \mathrm{Ma}$ and an evolving tectonic configuration created appropriate boundary conditions to generate "nearmodern" oceanic conditions in the Indo-Pacific. The Indo-Pacific Warm Pool (Figure F4) is trapped by the Indonesian archipelago and released into the Indian Ocean via the ITF (Gordon, 2005). The ITF transports $10-15$ Sverdrups $\left(1 \mathrm{~Sv}=10^{6} \mathrm{~m}^{3} / \mathrm{s}\right)$ of low-salinity warm water via the Indonesian archipelago (Kuhnt et al., 2004) to the Indian Ocean, forming an important switching point in the global thermohaline conveyor. The ITF cannot be considered in terms of an "open" or "closed" gateway but instead as the interaction between (1) the source of the water (south versus north Pacific), 
Figure F4. Oceanography and climate of the western Pacific (adapted from Gallagher et al., 2009). Currents (red = warm, blue $=$ cold) are indicated. The direction (green arrows) and geographic extent of the summer monsoon (dashed green lines) are adapted from Kershaw et al. (2003). The average January position of the ITCZ is shown (cf. Huang et al., 2011). Yellow stars = position of the three groups of drilling sites: northern group (Sites U1463 and U1464), second group (Sites U1461 and U1462), and most southerly group (Sites U1458, U1459, and U1460).

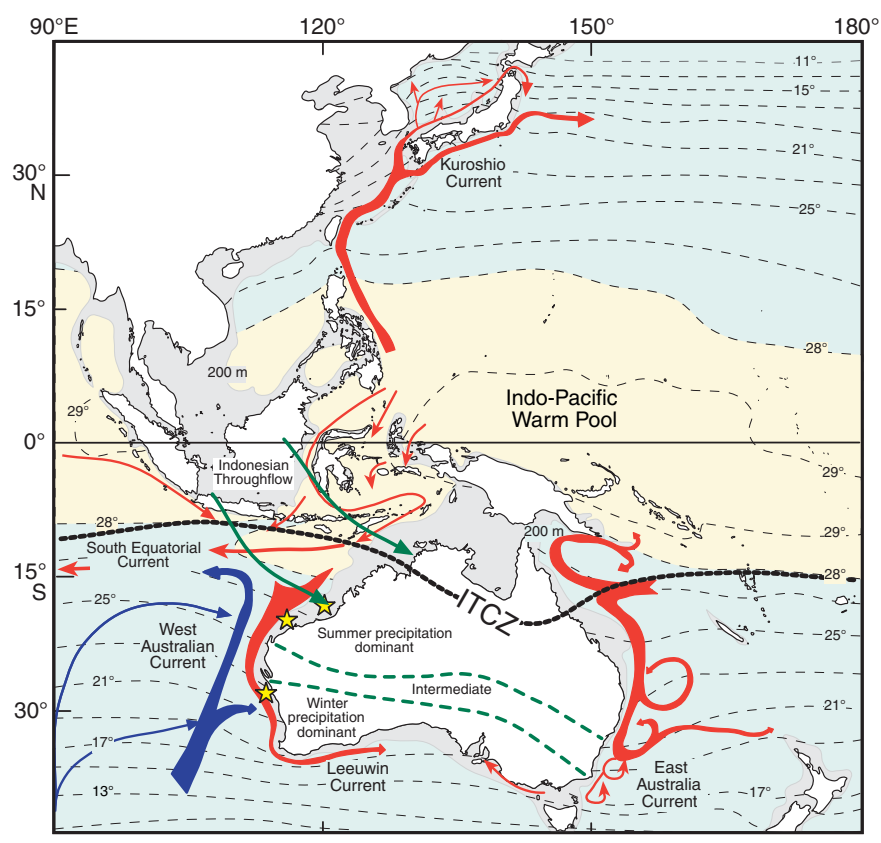

(2) the location of the main outlet, and (3) variable sill depths and locations through time (Kuhnt et al., 2004). The current eastern (main) outlet through the Timor Sea probably originated around 22.5 Ma. Until then, the Bali-Lombok Strait was more important (Kuhnt et al., 2004; Hall, 2009). The early history of the Indo-Pacific Warm Pool in the Indo-Pacific region has been interpreted from planktonic microfossils. Kennett et al. (1985) suggested that the Indo-Pacific Warm Pool formed as a result of Indonesian Seaway closure at $\sim 8 \mathrm{Ma}$. In contrast, Srinivasan and Sinha (1998) used planktonic foraminiferal biogeography to suggest its formation at $\sim 5.2 \mathrm{Ma}$. Jian et al. (2006) suggested a late Miocene ( 10 Ma) IndoPacific Warm Pool with the "modern" warm pool developing at $\sim 4$ Ma. Karas et al. (2011) used comparisons between the $\mathrm{Mg} / \mathrm{Ca}$ and stable isotope data from Ocean Drilling Program (ODP) Holes 709C and 763A on the western and eastern sides of the Indian Ocean, respectively (Figure F1), to suggest ITF restriction from 3.5 to $3 \mathrm{Ma}$ that caused $3^{\circ} \mathrm{C}$ cooling in those regions (Figure F5).

The extratropical shelf regions of the Indo-Pacific are strongly influenced by shallow $(50-300 \mathrm{~m})$ currents that originate in the Indo-Pacific Warm Pool region. For example, the NWS oceanography from $5^{\circ} \mathrm{S}$ to $15^{\circ} \mathrm{S}$ is dominated by the South Equatorial Current (Collins, 2002) (Figure F4). South of $15^{\circ} \mathrm{S}$, the shallow and narrow Leeuwin Current ( $<100 \mathrm{~km}$ wide, $<300 \mathrm{~m}$ deep) transports warm, low-salinity, nutrient-deficient water southward along the west coast of Australia (Pattiaratchi, 2006). It is driven by longshore winds and an upper-ocean pressure gradient (upper 250-300 m) (Tomczak and Godfrey, 1994) that overcomes equatorward wind stress and upwelling to flow south (Pattiaratchi, 2006). Another driver for this current is the steric height difference between the low-density and -salinity Timor Sea and the cooler, denser, saline
Figure F5. Pliocene-Pleistocene record of the NWS and its relationship to various tectonic and climatic events. Horizontal shaded bars = likely periods of Indonesian Seaway restriction. The benthic foraminifer $\delta^{18} \mathrm{O}$ curve is from Lisiecki and Raymo (2005). The NWS Indo-Pacific foraminiferal species distribution (from cuttings) is from Gallagher et al. (2009) and unpublished results from the Fisher-1 Well (adjacent to Site U1462). Sea-surface temperature data are from Hole 763A (Karas et al., 2011) (Figure F1).

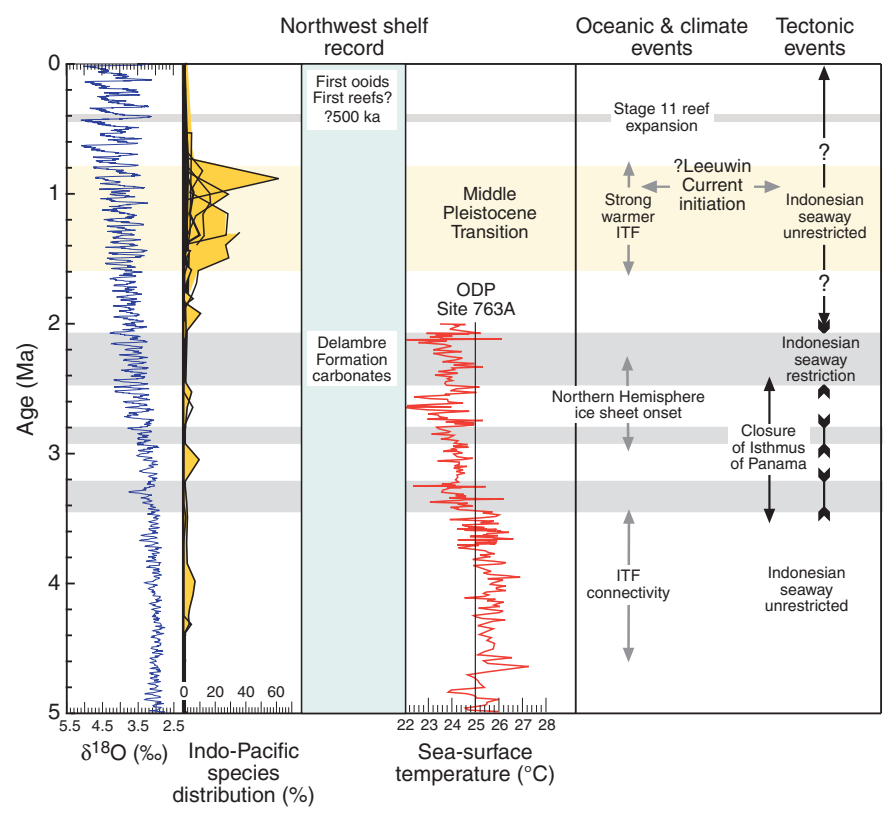

waters off the coast of Perth. It is the only south-flowing eastern boundary current in the Southern Hemisphere and has an enormous effect on the climate of the region. The Leeuwin Current extends modern coral reef development to $29^{\circ} \mathrm{S}$ (the HoutmanAbrolhos Reefs, Figure F1) (Collins et al., 1993) and the tropicalsubtropical transition as far south as Rottnest Island $\left(33^{\circ} \mathrm{S}\right.$; Greenstein and Pandolfi, 2008). Although the Late Pleistocene record and modern oceanography of the Leeuwin Current are well understood (see Cresswell, 1991; Pearce, 2009, and references therein), the preLate Pleistocene history of this current is not well known (Kendrick et al., 1991; Wyrwoll et al., 2009). James et al. (1999) suggested that the Leeuwin Current ceased during glacial periods and restarted during interglacials. Kendrick et al. (1991) used fossil mollusks to suggest that onset of the Leeuwin Current occurred more recently than $500 \mathrm{ka}$, whereas Sinha et al. (2006) and Karas et al. (2011) suggested onset at 2.5 Ma, and McGowran et al. (1997) proposed a late Eocene (40 Ma) onset age. However, Gallagher et al. (2009; 2014b) used microfossil biogeographic indicators in subsurface petroleum well samples from the NWS to suggest that the "modern" Leeuwin Current is younger than $1 \mathrm{Ma}$. Spooner et al. (2011) documented $500 \mathrm{ky}$ of Leeuwin Current variability from a deep-sea core (MD002361, $1805 \mathrm{~m}$ water depth) (Figure F1) using stable isotopes and planktonic foraminiferal proxies and suggested a weaker Leeuwin Current during glacial periods, when the West Australian Current was dominant, and a stronger Leeuwin Current during interglacials, especially marine isotope Stage (MIS) 11. The southerly migration of Indo-Pacific mollusks and corals to southwest Australia has also been used to document the Late Pleistocene history of the Leeuwin Current (Kendrick et al., 1991; Greenstein and Pandolfi, 2008).

The distribution and timing of coral reef development in west Australia is intimately related to the Leeuwin Current (Kendrick et 
al., 1991). Collins (2002) summarized late Neogene reef distribution in northwest Australia by describing a series of late Tertiary reefs that have developed discontinuously over time. The late Quaternary stratigraphic evolution of Scott Reef $\left(14^{\circ} \mathrm{S}\right)$, Rowley Shoals $\left(17.3^{\circ} \mathrm{S}\right)$, and Ningaloo $\left(22.7^{\circ} \mathrm{S}\right)$ and Houtman-Abrolhos $\left(28^{\circ} \mathrm{S}\right)$ Reefs (Figure F1) is related to a combination of increased subsidence amplitude toward the north, variability in the Leeuwin Current, and sea level change (Collins and Testa, 2010). Earlier reef development is less well constrained. Ryan et al. (2009) described a series of structurally controlled Miocene reefs from $15^{\circ} \mathrm{S}$ to $18^{\circ} \mathrm{S}$ using seismic data. These interpreted reefs drowned at the end of the late Miocene (Messinian) when they failed to keep up with sea level change. Further south $\left(22^{\circ} \mathrm{S}\right)$, Cathro et al. (2003) interpreted possible Miocene "barrier" reefs or mounds in seismic data. Liu et al. (2011) also interpreted possible Miocene reefs based on seismically imaged mounds in the same area. Ryan et al. (2009) acknowledged the dearth of post-Miocene and pre-late Quaternary reefs in the region. However, Jones (1973) and Ryan et al. (2009) described an unnamed postMiocene drowned "fossil" reef imaged using shallow- and deeppenetration seismic data close to the Rowley Shoals (Figure F1). Another series of drowned fossil reefs are shown in seismic data from $20^{\circ} \mathrm{S}$ to $22^{\circ} \mathrm{S}$ (Gallagher et al., 2014b).

\section{Climate and paleoclimate setting}

The arid to semiarid conditions of the Australian interior extend to the west coast of Australia. In the north, rainfall is erratic but predominantly monsoonal (Figure F4) with the summer rainfall dominance declining sharply toward the south (Sturman and Tapper, 2005). Warm, moist, equatorial air is the major source of monsoonal and cyclonic rain in the north but is replaced in the south by tropical air from the Indian Ocean, which is also known as the "pseudomonsoon" (Gentilli, 1972). The Australian summer monsoon delivers substantial precipitation to the northern part of the continent (north of $25^{\circ} \mathrm{S}$ ) from December to March (Suppiah, 1992; Herold et al., 2011). The winds blow predominantly from the northwest in the rainy season (austral summer), whereas in the dry season (austral winter) the winds blow from the southeast. These changes are associated with the seasonal migration of the subtropical highpressure belt from $40^{\circ} \mathrm{S}$ to $30^{\circ} \mathrm{S}$. In the austral winter, the Intertropical Convergence Zone (ITCZ) is north of Indonesia and moves south in austral summer to a position immediately north of Australia (Figure F4). The ITCZ moves even farther south over tropical Australia in February and is associated with the peak of the northern Australian wet season (Williams et al., 2009). The Australian monsoon is thought to be caused by land-ocean temperature contrasts and interhemispheric flow from the Asian monsoon. Australian monsoon strength and timing is influenced by changes in insolation resulting from obliquity and precessional forcing (Wyrwoll et al., 2007, 2012). The Australian summer monsoon lacks the topographic influence that controls the Indian-East Asian summer monsoon and is therefore weaker and more sensitive to variations in insolation (Wyrwoll et al., 2007). The region affected by the Asian and Australian monsoon systems $\left(70^{\circ} \mathrm{E}\right.$ to $\left.150^{\circ} \mathrm{E}\right)$ is one of the most significant heat sources driving global climate.

\section{The paleomonsoon}

An (2000) speculated that the histories of the East Asian and Australian monsoons are linked and that they originated before 7 Ma. Bowman et al. (2010) suggested (in the absence of any definitive northern Australia pre-Quaternary records) that "the (Australian) monsoon is of great antiquity" because of the pronounced diversity and strong adaptations of biota to the wet-dry tropical climate as well as their strong general adaptability. Herold et al. (2011) noted the incomplete knowledge of the nature and intensity of the preQuaternary Australian monsoon and investigated its potential impact on rainfall levels in the Miocene using a general circulation model constrained with a vegetation model. Herold et al. (2011) and Greenwood et al. (2012) compiled available paleontological proxy data for the Miocene and reconstructed a seasonally wet northern and interior Australia, supporting a biome (i.e., seasonally dry deciduous vine forests and sclerophyllous woodlands) consistent with a monsoonal precipitation regime wetter than today. The only pollen record from the semiarid northwest Australian continent is west of the Cape Range Peninsula (Core GC17) (Figure F1) and spans the last $100 \mathrm{ky}$ (van der Kaars and De Deckker, 2002; van der Kaars et al., 2006). This location is at the southern extremity of the Australian summer monsoon and receives $200-300 \mathrm{~mm}$ of rainfall per year, making it ideal to record changes in the latitudinal position of the monsoon (Figure F4). Van der Kaars et al. (2006) used transfer functions to interpret rainfall from the pollen record and hypothesized that a marked reduction in summer rainfall occurred in the absence of monsoonal activity during the Last Glacial Maximum. Other deep-water Quaternary records of the Australian monsoon have been obtained from farther north in the Timor Sea $\left(13^{\circ} \mathrm{S}\right.$, Holbourn et al., 2005) and in the Banda Sea $\left(5^{\circ} \mathrm{S}\right.$, Beaufort et al., 2010; $8.5^{\circ} \mathrm{S}$, Spooner et al., 2005). Holbourn et al. (2005) used foraminiferal and geochemical proxies to chart Timor Sea paleoproductivity over the last $350 \mathrm{ky}$ and noted that the Timor Sea productivity record matches the $25^{\circ} \mathrm{S}$ summer insolation curve, which they interpreted to have strong precessional and eccentricity control. This observation indicates that tropical and/or Southern Hemisphere insolation forcing is an important modulating factor for Australian monsoon intensity. Spooner et al. (2005) combined stable isotope analyses with planktonic foraminiferal assemblages to interpret the 80 ky variability of the monsoon and concluded that it was less intense during the first $60 \mathrm{ky}$ then intensified at $\sim 15 \mathrm{ka}$. Beaufort et al. (2010) used calcareous nannofossils to suggest precessional control on primary productivity and Australian monsoon intensity over the last $150 \mathrm{ky}$. The Australian monsoon is interpreted to be broadly controlled by global glacial-interglacial variations (Wyrwoll and Miller, 2001). Strong variations in Australian monsoonal strength between glacial and interglacial periods (paced by orbital eccentricity and precession) have been documented over the last $460 \mathrm{ky}$ off northwest Australia (Kawamura et al., 2006) with stronger monsoonal (wet) conditions prevailing during interglacial periods and a weakened monsoon (dry) during glacials. This pattern of glacial-interglacial precipitation variance was further suggested in a $550 \mathrm{ky}$ dust record from offshore North West Cape (Stuut et al., 2014). Significant fluvial runoff and megalake expansion across northern and central Australia (Hesse et al., 2004) occurred during interglacials over the last 300 ky because of Australian monsoon enhancement. Conversely, reduced precipitation on the NWS (at $23^{\circ} \mathrm{S}$, van der Kaars et al., 2006) and megalake contraction typified glacial conditions (Magee et al., 2004), associated with decreased monsoonal activity.

Little is known about the timing of the development of the characteristic synoptic-scale division of Australia into a winter-wet south and summer-wet north. At a first approximation, the intensity and timing of monsoonal northern Australia and frontal-dominated southern Australia are both controlled by the intensity and seasonal migration of the subtropical anticyclone. Hence, the history of the southern subtropical anticyclone may be critical to our understanding of the evolution of synoptic systems at both ends of the continent. However, it is unknown whether the late Neogene evolution of 
the Australian monsoon was synchronized with contemporaneous climatic evolution in the southern part of the continent. Nevertheless, the timing of patterns seen in the gamma radiation maxima of the NWS (Figure F6) shows similarities with data from southeastern Australia. For example, fossil insect and pollen analyses from a small upland paleolake in southeastern Australia indicate that high annual and summer rainfall persisted there until at least $1.5 \mathrm{Ma}$ (Sniderman et al., 2009, 2013), which is inconsistent with the modern climate and vegetation patterns. Drying of a megalake in what is now the semiarid interior of southeastern Australia did not occur until the early Pleistocene (1.5-1.4 Ma; McLaren and Wallace, 2010; McLaren et al., 2011, 2012, 2014). In central Australia, there is evidence that the final phase of aridification, marked by the presence of active dune fields, did not initiate until $\sim 1 \mathrm{Ma}$ (Fujioka and Chappell, 2010). Hence, it is possible that the onset of modern patterns of rainfall seasonality across the continent, as well as the initiation of full aridity in inland Australia, were synchronized. Further insight into the relative input from precipitation can be obtained by analyzing the clay mineralogy of the marly facies (Gingele et al., 2001a, 2001b). The percent kaolinite/illite/chlorite content in each horizon will vary depending on the relative intensity of precipitation and runoff from the source coastal hinterland. For example, reduced chlorite associated with a decrease in kaolinite is interpreted to indicate arid conditions on the NWS during the Holocene (Gingele et al., 2001b). In addition, geochemical analyses of dust in NWS sediments have been used as a relative aridity index (Stuut et al., 2014).
Turney et al. (2006) suggested that late Quaternary climatic variability across northern Australia probably reflected changes in the latitude of the ITCZ, the westerlies, and ocean masses. However, these authors stated that "few local records are available that enable the frequency, timing, and latitudinal span to be reconstructed with great confidence." They note that biological or geomorphic proxy evidence might often show a time-transgressive response to climatic variability. They concluded with a plea to perform quantitative reconstructions of past climates in this region with a refined chronology. Biodiversity studies emphasize the uniqueness of the Australian monsoon biota (Crisp and Cook, 2013; Oliver et al., 2014) as it evolved in response to the changing monsoon and increased aridity in the Neogene.

\section{Sedimentation history}

The northward drift of Australia led to a transition from siliciclastic to predominantly carbonate deposition on the NWS. Carbonate sedimentation was already dominant by the Eocene, although a siliciclastic component persisted (Hull and Griffiths, 2002). This drift brought the NWS into tropical latitudes (Veevers et al., 1991; Müller et al., 2008a); the region had reached $36^{\circ} \mathrm{S}-40^{\circ} \mathrm{S}$ by the early Oligocene and is now at $18^{\circ} \mathrm{S}-22^{\circ} \mathrm{S}$ (Figure F2). Prograding carbonate clinoforms developed in the early Oligocene and continued to the Miocene (Hull and Griffiths, 2002; Cathro et al., 2003). Late early Oligocene-early late Miocene carbonate sedi-

Figure F6. Correlation of gamma logs from eight wells (locations on Figure F1) in the NWS. The top Miocene/base Pliocene (orange) is based on age data (green numbers) from Expedition 356 drilling and Gallagher et al. (2009, 2014b) for Goodwyn-7 and Goodwyn-6. Fm = formation. gAPI = American Petroleum Institute gamma radiation units. Depth is in meters below sea surface.

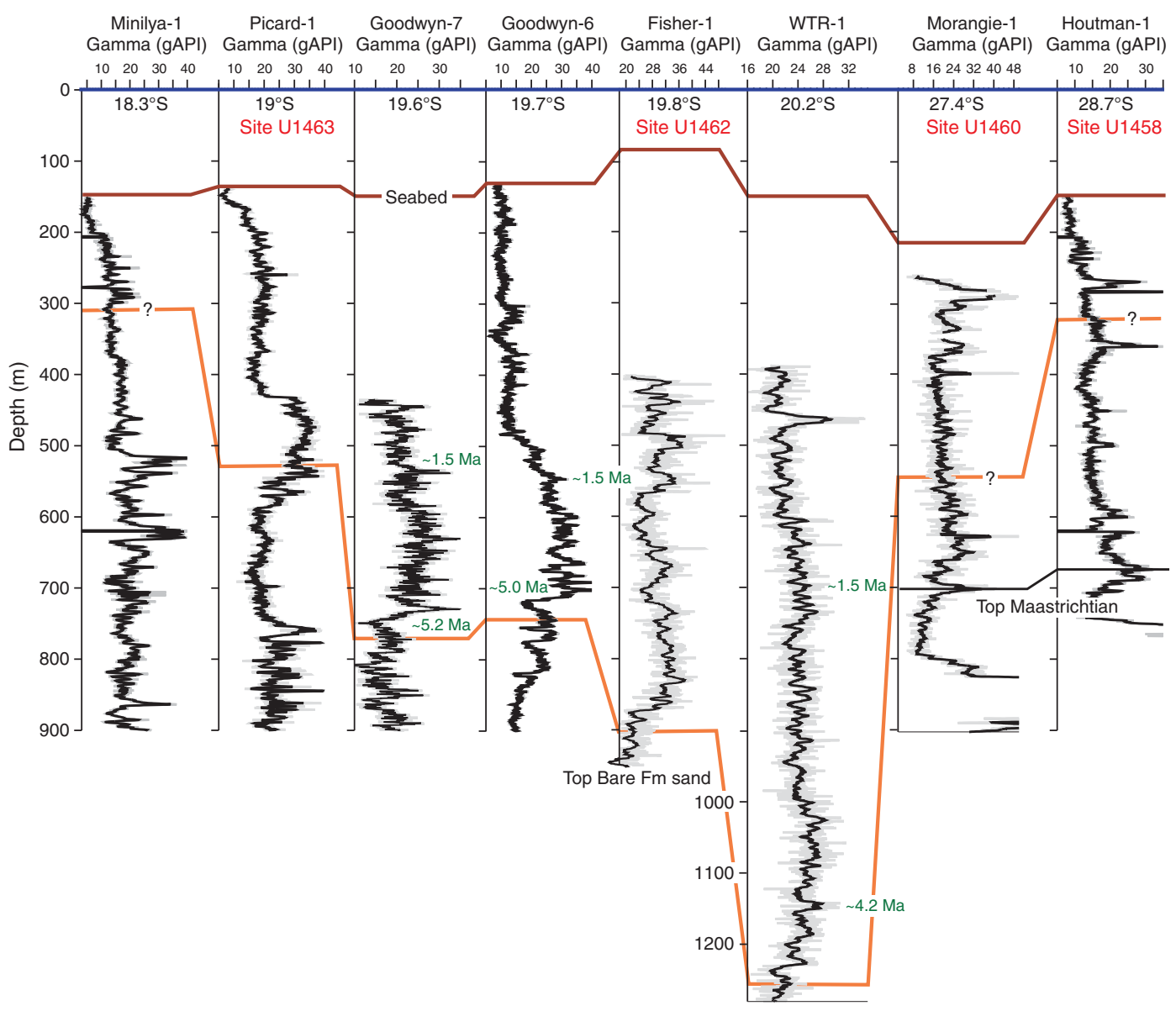


ments are heterozoan (i.e., derived from light-independent organisms) and include benthic foraminifers with subordinate bryozoans and rare coral fragments (Cathro et al., 2003). Such sediments develop unrimmed platforms lacking reefs. Resulting clinoformal sequences comprise fine-grained calcilutites on the slope, a mixture of calcisiltites and calcarenites near clinoform rollovers (equivalent to paleoshelf edges), and calcarenites on paleoshelves (Hull and Griffiths, 2002; Moss et al., 2004). Evidence for pre-Quaternary reef development is limited; seismically identified reefs or reef mounds occur in the Oligocene-Miocene section (Romine et al., 1997; Cathro et al., 2003; Ryan et al., 2009; Liu et al., 2011). Rare reefs also occur in the Pliocene-Quaternary section (Ryan et al., 2009; Gallagher et al., 2014b), and conditions were favorable for late Quaternary reef development even farther south to $28^{\circ} \mathrm{S}$ (Collins, 2002). However, sedimentation rates, even in temperate water carbonates, can be high ( $>40 \mathrm{~cm} / \mathrm{ky})$, comparable to the lower end of the spectrum of tropical carbonate platform growth rates (James and Bone, 1991).

\section{Previous drilling in the region}

The NWS has been extensively drilled by industry over the last 40 y (Longley et al., 2002). Previous work by both academia and industry on the NWS has provided abundant site data, including well completion reports, seismic data, wireline logs, cuttings, (rare) sidewall cores, and limited engineering cores in the latest Quaternary sections. However, cores that sampled the upper kilometer (Miocene to Holocene carbonate section) are extremely rare. The only continuous cores that existed prior to Expedition 356 were from engineering boreholes, typically sampling Late Pleistocene carbonates in the upper $\sim 150 \mathrm{~m}$ (Figure F7), and intermittent sidewall cores (Figure F5). There are industry wells near each of the Expedition 356 sites; these wells provided data in the form of gamma wireline logs (mostly to the seabed; Figure F6) and cuttings samples. Addi- tionally, there are two continuously cored engineering boreholes (BHC4 and BHC1) near the Angel-1 Well (19.5'S; Figures F1, F7) (Gallagher et al., 2014b). Facies data $\left(\% \mathrm{CaCO}_{3}\right)$ from these engineering boreholes are directly comparable to the LR2004 oxygen isotope record (Lisiecki and Raymo, 2005). For example, the lower carbonate marly facies (with relatively high gamma response) were deposited during interglacial highstands, and the high-carbonate calcarenites (with ooids) were deposited as the sea level fell during glacials. It is likely that the presence of increased siliciclastics (gamma peaks) on the NWS is related to increased precipitation and terrestrial runoff during the interglacial periods from an enhanced Australian monsoon. The decrease in terrestrial input during glacials was due to increasingly arid conditions, starving the shelf of siliciclastics (Gallagher et al., 2014b). This sedimentation model is likely applicable throughout the Pliocene-Pleistocene shelfal carbonate section (Figure F6) because regional subsidence has likely facilitated the preservation of the majority of the eccentricity/obliquity-controlled eustatic cycles throughout this period (Gallagher et al., 2014b).

In addition, the gamma log pattern clearly changes through time: Pliocene strata are more gamma rich and there is a secular shift to lower values during the Pleistocene (Figure F6). This could reflect progressive changes in shelf geometry; however, this effect can be corrected for using paleobathymetric estimates in each section. Furthermore, the prevalence of this upward decreasing gamma pattern across $10^{\circ}$ of latitude suggests a more regional mechanism, such as an increase of aridity through time and decreasing influence of the Australian monsoon. The shelfal sections also yield well-preserved Globigerinoides ruber and Cibicidoides spp. (plus many other benthic foraminiferal species) in the interglacial marly facies. The G. ruber and Cibicidoides spp. exhibit isotope values close to deepsea Pleistocene values in the region (Wells and Wells, 1994), providing an opportunity to use proxy data for salinity and temperature

Figure F7. A. Benthic foraminifer $\delta^{18} \mathrm{O}$ curve (LR2004) and MIS ages from Lisiecki and Raymo (2005) correlated with wells and cores in the Angel-1 region (Figure F1). B. Carbonate in Core BHC4. C. Carbonate in Core BHC1. D. Gamma log for Angel-1 (Figure F6). Vertical scale for B-D is in meters below sea surface and Cores $\mathrm{BCH} 4$ and $\mathrm{BCH} 1$ and the Angel-1 Well are $\sim 50 \mathrm{~m}$ apart.

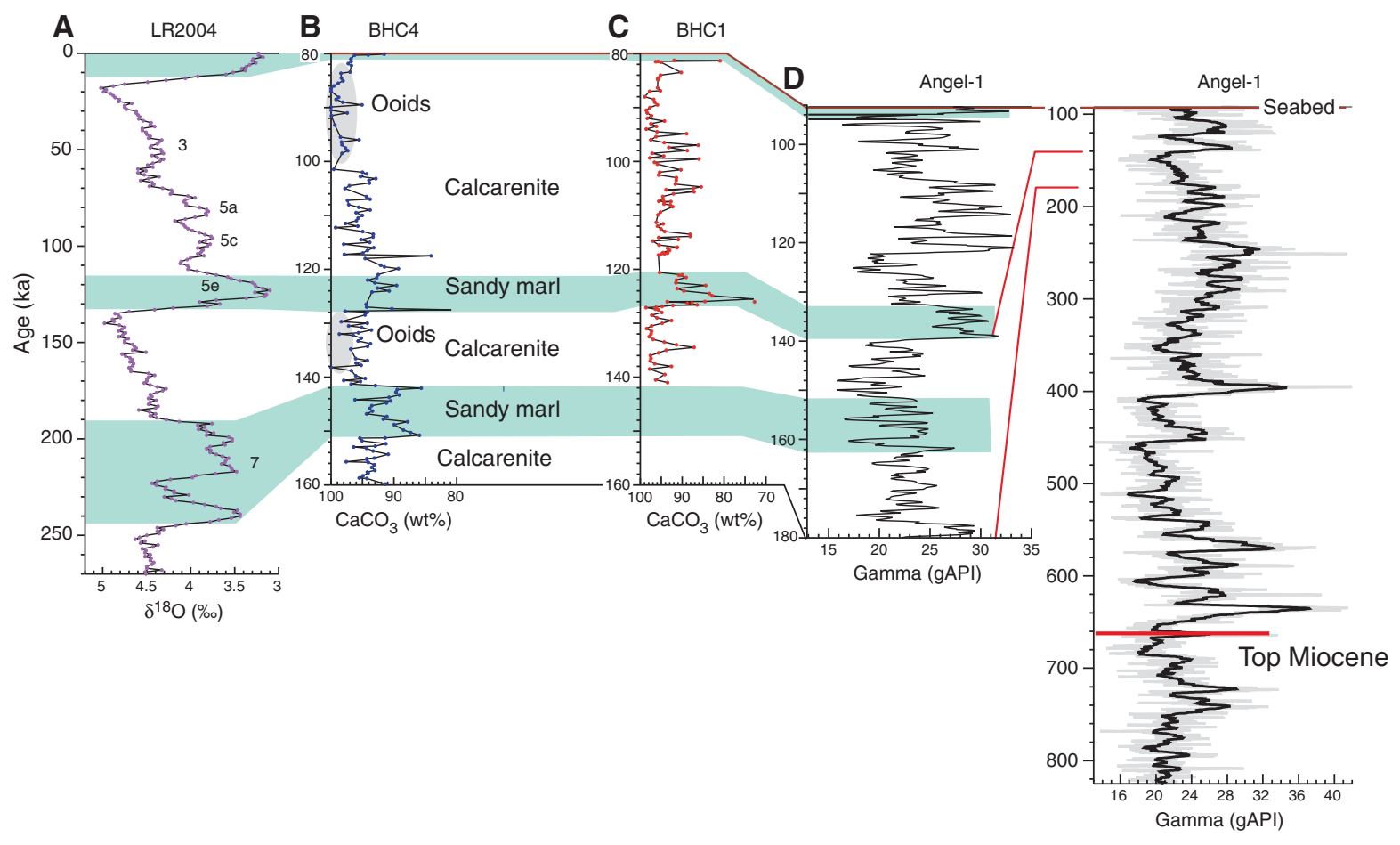


variations (such as paired $\mathrm{Mg} / \mathrm{Ca}$ and $\delta^{18} \mathrm{O}$ analyses) for each glacial cycle to investigate the influence of the Indo-Pacific Warm Pool and ITF on the region and their relationship to the Leeuwin Current.

\section{Chronostratigraphic framework}

A wealth of information was already available on the chronostratigraphic framework in the region, and this information was particularly useful as background for the expedition.

\section{Biostratigraphy}

Planktonic foraminifers and nannofossils are common in NWS shelfal sections, especially the highstand and outer shelf to upper slope facies, but they are absent in the oolitic facies and poorly preserved in the coarse calcarenites. They are abundant in all the facies of the West Tryal Rocks-1 Well (near Site U1461; Figure F8; see data and zonation in Gallagher et al., 2009). There are also a few useful dinoflagellate datums (McMinn, 1992, 2002) in the Pliocene-Pleistocene section to assist age calibration.

\section{Magnetostratigraphy}

Typically, this technique is used to provide a chronostratigraphy for deep-water siliciclastics or carbonates. However, Sakai and Jige (2006) successfully demonstrated that magnetostratigraphy is also useful in calibrating Pleistocene shallow-water tropical carbonates in the Ryukyus (Japan).

\section{Correlation to oxygen isotope curves}

With a few biostratigraphic calibration points, it is possible to correlate log gamma maxima to interglacial cycles (Gallagher et al., 2014b), similar to the approach adopted by Carter and Gammon (2004). These authors correlated the gamma profile from ODP Site 1119 to oxygen isotope data to achieve a millennial-scale record of New Zealand upper slope sedimentation for the last 3.9 My. This type of wireline analysis has also revealed Pliocene-Pleistocene 40 ky-scale climate variability in the Japan Sea (deMenocal et al., 1992).

\section{Carbon isotope dating}

There are sufficiently well preserved mollusks in the upper parts of the sections to permit carbon isotope dating. This technique has already been applied successfully near the top of Core BHC4 (Figure F7).

\section{Strontium isotope dating}

With thorough petrographic screening for diagenetic effects, such as subaerial exposure, it is possible to use strontium isotopes from bioclasts to construct age-depth profiles. Ehrenberg et al. (2006) have successfully dated calcitic bioclasts, such as bivalves, red algae, and large benthic foraminifers (LBFs), from Miocene platform carbonates.

\section{Operations strategy}

The operational strategy for Expedition 356 is described in detail in the Scientific Prospectus (Gallagher et al., 2014a). In brief, Expedition 356 site locations were designed to sample the lateral variability $\left(\right.$ over $10^{\circ}$ ) in subsidence and tropical conditions along the NWS over the last 5 My (Figure F1), specifically targeting tropical reef and carbonate diachroneity, related to Leeuwin Current inten-

Figure F8. Site U1461 (yellow star; adjacent West Tryal Rocks-2 Well is also shown) on an interpreted seismic profile (A-A') with "fossil" reefs (light green). See Gallagher et al. (2009, 2014b) for age-depth model (from cuttings) for the five wells: West Tryal Rocks-1 (WTR 1), Tryal Rocks-1 (TR 1), Maitland North-1 (MN 1), Maitland-1 (M 1), and Austin-1 (A 1). The numbers (0.5-4.0) are reflector ages in millions of years. Regional site and well locations are shown on Figure F1. Fm = formation.

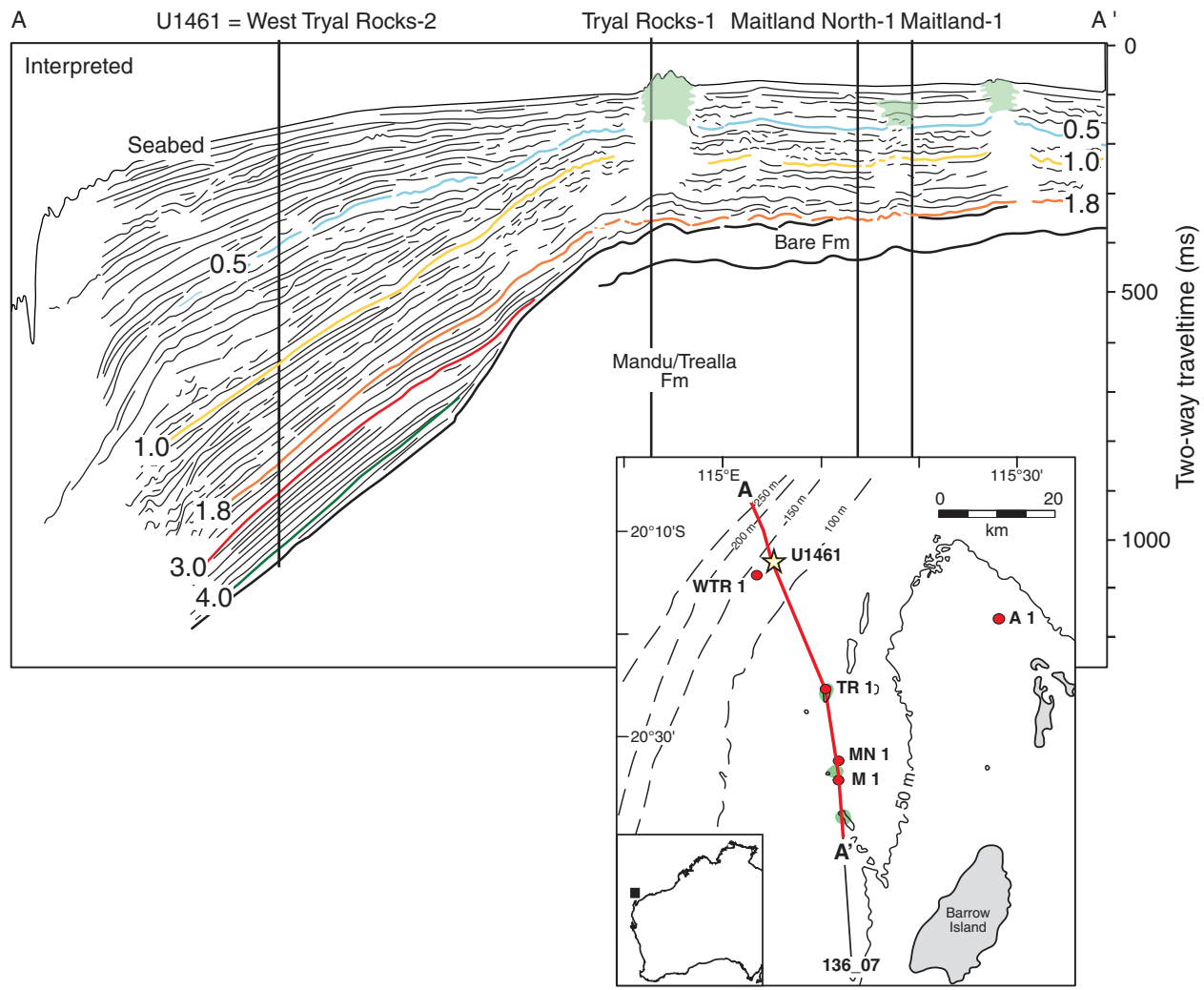


Table T1. Expedition 356 sites and adjacent industry wells. Download table in .csv format.

\begin{tabular}{|c|c|c|c|c|c|c|c|c|}
\hline Site & Hole & Latitude & Longitude & $\begin{array}{l}\text { Water depth } \\
\text { (mbsl) }\end{array}$ & $\begin{array}{c}\text { Adjacent } \\
\text { industry well }\end{array}$ & Latitude & Longitude & $\begin{array}{l}\text { Water depth } \\
\text { (mbsl) }\end{array}$ \\
\hline U1458 & A & $28^{\circ} 39.8475^{\prime} \mathrm{S}$ & $113^{\circ} 34.6676^{\prime} \mathrm{E}$ & 156.77 & Houtman-1 & $28^{\circ} 39.846^{\prime} \mathrm{S}$ & $113^{\circ} 34.668^{\prime} \mathrm{E}$ & 152 \\
\hline \multirow[t]{3}{*}{ U1459 } & A & $28^{\circ} 40.2606^{\prime} \mathrm{S}$ & $113^{\circ} 33.5376^{\prime} \mathrm{E}$ & 192.27 & Houtman-1 & $28^{\circ} 39.846^{\prime} \mathrm{S}$ & $113^{\circ} 34.668^{\prime} \mathrm{E}$ & 152 \\
\hline & B & $28^{\circ} 40.2519^{\prime} \mathrm{S}$ & $113^{\circ} 33.5375^{\prime} \mathrm{E}$ & 192.32 & & & & \\
\hline & C & $28^{\circ} 40.2398^{\prime} \mathrm{S}$ & $113^{\circ} 33.5365^{\prime} \mathrm{E}$ & 192.35 & & & & \\
\hline \multirow[t]{2}{*}{ U1460 } & A & $27^{\circ} 22.4949^{\prime} \mathrm{S}$ & $112^{\circ} 55.4296^{\prime} \mathrm{E}$ & 214.5 & Morangie-1 & $27^{\circ} 22.494^{\prime} \mathrm{S}$ & $112^{\circ} 55.5^{\prime} \mathrm{E}$ & 214 \\
\hline & B & $27^{\circ} 22.4867^{\prime} \mathrm{S}$ & $112^{\circ} 55.4265^{\prime} \mathrm{E}$ & 214.36 & & & & \\
\hline \multirow[t]{4}{*}{ U1461 } & A & $20^{\circ} 12.8634^{\prime} \mathrm{S}$ & $115^{\circ} 03.9495^{\prime} \mathrm{E}$ & 127.18 & West Tryal Rocks-2 & $20^{\circ} 12.8628^{\prime} \mathrm{S}$ & $115^{\circ} 04001^{\prime} \mathrm{E}$ & 126 \\
\hline & B & $20^{\circ} 12.8522^{\prime} \mathrm{S}$ & $115^{\circ} 03.9396^{\prime} \mathrm{E}$ & 127.97 & & & & \\
\hline & C & $20^{\circ} 12.8427^{\prime} \mathrm{S}$ & $115^{\circ} 03.9369^{\prime} \mathrm{E}$ & 127.52 & & & & \\
\hline & D & $20^{\circ} 12.8325^{\prime} \mathrm{S}$ & $115^{\circ} 03.9389^{\prime} \mathrm{E}$ & 127.48 & & & & \\
\hline \multirow[t]{3}{*}{ U1462 } & A & $19^{\circ} 49.2857^{\prime} \mathrm{S}$ & $115^{\circ} 42.5984^{\prime} \mathrm{E}$ & 87.15 & Fisher-1 & $19^{\circ} 49.338^{\prime} \mathrm{S}$ & $115^{\circ} 42.619^{\prime} \mathrm{E}$ & 88 \\
\hline & B & $19^{\circ} 49.2801^{\prime} \mathrm{S}$ & $115^{\circ} 42.6091^{\prime} \mathrm{E}$ & 87.19 & & & & \\
\hline & C & $19^{\circ} 49.2764^{\prime} \mathrm{S}$ & $115^{\circ} 42.6186^{\prime} \mathrm{E}$ & 87.19 & & & & \\
\hline \multirow[t]{4}{*}{ U1463 } & A & $18^{\circ} 57.9181^{\prime} \mathrm{S}$ & $117^{\circ} 37.4217^{\prime} \mathrm{E}$ & 145.81 & Picard-1 & $18^{\circ} 57.918^{\prime} \mathrm{S}$ & $117^{\circ} 37.422^{\prime} \mathrm{E}$ & 141 \\
\hline & B & $18^{\circ} 57.9190^{\prime} \mathrm{s}$ & $117^{\circ} 37.4340^{\prime} \mathrm{E}$ & 145.41 & & & & \\
\hline & C & $18^{\circ} 57.9295^{\prime} \mathrm{S}$ & $117^{\circ} 37.4336^{\prime} \mathrm{E}$ & 144.81 & & & & \\
\hline & D & $18^{\circ} 57.9285^{\prime} \mathrm{S}$ & $117^{\circ} 37.4216^{\prime} \mathrm{E}$ & 144.5 & & & & \\
\hline \multirow[t]{4}{*}{ U1464 } & A & $18^{\circ} 03.9125^{\prime} \mathrm{S}$ & $118^{\circ} 37.8824^{\prime} \mathrm{E}$ & 259.96 & & & & \\
\hline & B & $18^{\circ} 03.9115^{\prime} \mathrm{S}$ & $118^{\circ} 37.8935^{\prime} \mathrm{E}$ & 264.26 & & & & \\
\hline & C & $18^{\circ} 03.9244^{\prime} \mathrm{S}$ & $118^{\circ} 37.8942^{\prime} \mathrm{E}$ & 264.24 & & & & \\
\hline & D & $18^{\circ} 03.9230^{\prime} \mathrm{S}$ & $118^{\circ} 37.8836^{\prime} \mathrm{E}$ & 264.43 & & & & \\
\hline
\end{tabular}

sity and ITF/Indo-Pacific Warm Pool influence, together with investigation of subsidence history and dynamic topography.

Expedition 356 Sites U1458 (proposed Site NWS-6A), U1460 (proposed Site NWS-5A), U1461 (proposed Site NWS-4A), U1462 (proposed Site NWS-3A), and U1463 (proposed Site NWS-2A) are located within $150 \mathrm{~m}$ of preexisting industry wells (Table T1). Sites U1459 (proposed Site NWS-13A) and U1464 (proposed Site NWS7A) were originally alternate site locations near Sites U1458 and proposed primary Site NWS-1A, respectively. These sites were cored when conditions were either unfavorable at the original site, as in the case of Site U1459, or when a review of the available seismic data on board the ship suggested the alternate site was more likely to achieve the science objectives (Site U1464).

The original operations plan anticipated triple piston coring of the upper sections at each site followed by deepening two of the holes with coring via the extended core barrel (XCB) system. Two of the deeper penetration sites (U1461 and U1462) were expected to include coring with the rotary core barrel (RCB) system to reach the target depth. The deepest penetration hole at all sites was planned to include wireline logging. However, this operations plan was not followed in some cases (see Operations in each site chapter for details) because the nature of the seafloor and the upper sediments precluded piston coring. This was particularly true for the southern sites (U1458 and U1459), where hard layers necessitated the use of the XCB system at the seafloor (see Operations in the Site U1458 chapter and Operations in the Site U1459 chapter [Gallagher et al., 2017b, 2017c]). Despite the challenges encountered during operations, excellent material was recovered to address the scientific objectives.

\section{Principal results}

During Expedition 356, seven sites were cored over a latitudinal range from $29^{\circ} \mathrm{S}$ to $18^{\circ} \mathrm{S}$ on the NWS (Table T2). In total, we recovered $5185.15 \mathrm{~m}$ of core, with $62 \%$ recovery, and gathered an unpar- alleled archive of tropical to warm temperate climate and paleoceanography along the continental margin of Australia. Postcruise research will provide further insights on the complex interrelationships between subsidence, reef development, ITF variability, the Australian monsoon, and the onset of aridity in Australia over the last 5 My.

Sites U1459, U1461, and U1464 (Figure F1) have revealed insights into the timing and onset of reef development and are important because the pre-late Quaternary history of tropical reef development on the NWS is poorly known. The shelfal sites provide biogeographic evidence of ITF connectivity (Figure F5), yielding a downstream record of this important ocean gateway. Sites U1461 and U1462 yielded ooids of Pleistocene age. Knowing the temporal and spatial distribution of ooids on the NWS also provides insights into regional aridity and Indian Ocean alkalinity, and these data can also be used as paleodepth indicators. The presence of bathymetrically diagnostic microfossil biofacies, such as larger and smaller benthic foraminifers, at each of the expedition's sites should permit construction of well-constrained subsidence histories across $10^{\circ}$ latitude, allowing the detailed temporal history of dynamic subsidence of the northern Australian plate to be constructed for the first time. All of the sites are likely to yield spores and pollen and therefore provide a record of vegetation-type shifts that will improve our understanding of the timing and nature of monsoonal variability and aridification in northwestern Australia. Compared to the eolian-derived floral assemblages from deep oceanic sites, material recovered from the NWS, closer to the shoreline, contains predominantly fluvial-derived assemblages that contribute to a more realistic assessment of regional climate. In particular, shelfal to upper slope targets (Sites U1460-U1464) provide particularly important climate records. Sites U1461-U1464 were anticipated to provide insight into the onset and dynamics of the Australian monsoon and its relationship to obliquity forcing. Cores from these sites represent an increase in our understanding of this important climate system because previous studies in the region focused only on the last 200 
Table T2. Expedition 356 hole summary. Hole U1458A was abandoned due to poor recovery and difficult coring conditions at the seafloor. DSF $=$ drilled depth below seafloor. APC = advanced piston corer, HLAPC = half-length advanced piston corer, $\mathrm{XCB}=$ extended core barrel, $\mathrm{RCB}=$ rotary core barrel. Download table in .csv format.

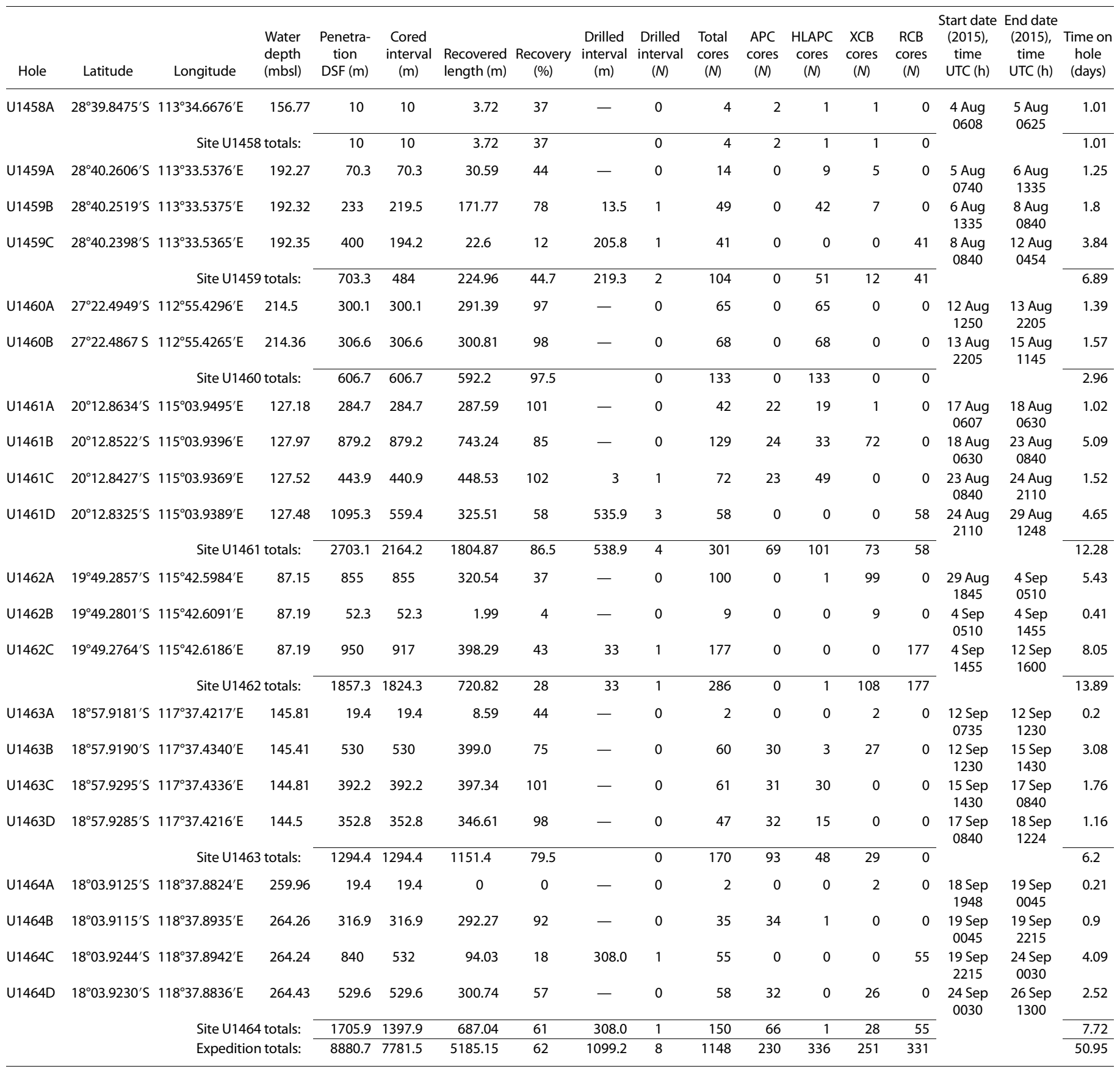

ky. Site U1460 was not expected to yield an orbital-scale climate record because of slope erosional processes; however, it may indeed yield an orbital-scale record and complements Sites U1461-U1464 because it lies south of a climatic divide between the Australian monsoon-dominated northern area and the westerly wind-driven, winter rainfall-dominated southern area (Figure F4). Site U1460 therefore provides a Pliocene-Pleistocene record of onset and variability of the southern Australian winter rainfall-dominated regime.

\section{Site summaries}

\section{Site U1458}

Site U1458 lies in the northern part of the Perth Basin, adjacent to the Houtman-1 Well on the northern Rottnest shelf (James et al., 1999; Collins et al., 2014). The site is seaward of and downdip from the Houtman-Abrolhos main reef complex, which contains the most southerly tropical reefs in the Indian Ocean. Site U1458 was the southernmost site of our latitudinal transect. The evolution of 
this reef complex is directly related to the path of the Leeuwin Current. Dating of sediments cored at Site U1458, coupled with seismic correlation, could provide insights into the pre-Quaternary history of these reefs and a long-term perspective on Leeuwin Current evolution at the tropical/subtropical boundary off Western Australia. In addition, it has been suggested that subsidence rates over the last 140 ky were low compared to those of the reefs of the Carnarvon Basin (Collins and Testa, 2010), so subsidence analyses of the site's shelf sequence would extend this record and allow more precise modeling of dynamic subsidence along the western margin of Australia.

Unfortunately, we were unable to effectively core and recover material at Site U1458, and the site was abandoned in favor of Site U1459, located $\sim 1 \mathrm{nmi}$ seaward of Site U1458 and in water $\sim 50 \mathrm{~m}$ deeper, where it was anticipated that a finer grained section would be encountered. As a result of the poor recovery and shallow penetration, paleomagnetic data were not produced at this site and no discrete samples were taken. Downhole logging and stratigraphic correlation were not attempted.

\section{Lithostratigraphy}

Site U1458 yielded a total of 3.72 m of core. The material recovered in all cores was normally graded because of sorting of the sediment within the core liner during coring and recovery. The poor recovery and potential reworking of sediments prevented the definition of lithostratigraphic units, so only the lithology was described.

The core recovered from Hole U1458A suggests a hard seafloor comprising a $\sim 10 \mathrm{~cm}$ thick lithified layer, with a soft-sediment cover in the mudline sample. Sediment below the lithified layer is unlithified skeletal grain- to rudstone containing coarse rhodolith-bearing gravel to fine-grained carbonate sand. Diverse macro- and microfossil assemblages found in diminishing order of abundance included rhodoliths, mollusk fragments, bryozoans, calcareous and siliceous sponge spicules, and benthic and planktonic foraminifers. Smear slide analyses indicate that the rudstones are predominantly skeletal fragments of mollusks and bryozoan colonies. The occurrence of well-rounded to ellipsoidal gravel to coarse sand sediment indicates moderate-energy currents in the area.

\section{Biostratigraphy and micropaleontology}

Three core catchers (CC) were sampled from Cores 356U1458A-1H, 2H, and 4F. Core $3 \mathrm{X}$ did not yield any core catcher material. In addition to foraminifers and nannofossils, bryozoans, ostracods, and pteropods are present. A mudline sample was also taken from this site. Calcareous nannofossils were observed in core catchers from Cores $1 \mathrm{H}, 2 \mathrm{H}$, and $4 \mathrm{~F}$ and the mudline sample. Calcareous nannofossil abundance is very low and their preservation is poor to good. The youngest biostratigraphic event in the mudline sample is based on the occurrence of Emiliania huxleyi. The estimated age is $<0.29 \mathrm{Ma}$, or Zone NN21. Section $1 \mathrm{H}-\mathrm{CC}$ contains a recent-Pleistocene assemblage with Neogene reticulofenestrids that were likely reworked. From the base of Core $1 \mathrm{H}$ to the bottom of Hole U1458A (9.95 m core depth below seafloor [CSF-A]), gephyrocapsids are very common, with a dominance of Gephyrocapsa caribbeanica. Based on gephyrocapsids and G. caribbeanica in the samples, the estimated age at total depth is younger than $1.73 \mathrm{Ma}$.

The samples contain between $12 \%$ and $66 \%$ planktonic foraminifers, and preservation varies between poor and moderate. In Section 356-U1458A-2H-CC, around $10 \%$ of specimens were reworked. There is evidence of diagenesis and inorganic precipitation and/or recrystallization in Section 4F-CC. The overall diversity is low, with around five or six different species in each sample. G. ruber (white), Globigerinoides conglobatus, Globigerinoides sacculifer (without sac), Globorotalia crassaformis, Globorotalia menardii, Globorotalia tosaensis, and Neogloboquadrina dutertrei are present. The top of G. tosaensis is reported to be at $\sim 0.61 \mathrm{Ma}$, according to Gradstein et al. (2012). The specimens of this species did not appear to be reworked. Thus, unless they were transported from the slope, this marker species gives an age of $\sim 0.61 \mathrm{Ma}$ for the base of Core $2 \mathrm{H}$.

The samples contain between $35 \%$ and $88 \%$ benthic foraminifers, dominated by Quinqueloculina lamarckiana and Amphistegina lessonii and abundant Cibicidoides spp. In each sample, 11-23 species were observed. Preservation is poor, and fragmentation varies from poor to very poor. Encrustation and heavy abrasion on tests impeded identification of some taxa to species level, indicating reworking. Section 356-U1458A-1H-CC contains warm-temperate, shallow-water foraminifers.

\section{Geochemistry}

Three samples were analyzed for headspace gas content, all of which showed very low subsurface methane $(<2.5$ parts per million by volume [ppmv]). Inorganic and organic carbon content and interstitial water (IW) geochemistry measurements were not conducted.

\section{Physical properties}

Physical properties measurements at Site U1458 were collected using the Whole-Round Multisensor Logger (WRMSL), natural gamma radiation (NGR) sensor, $P$-wave velocity caliper, and discrete sampling. Gamma ray attenuation (GRA) bulk density averaged $1.33 \mathrm{~g} / \mathrm{cm}^{3}$ in Cores $356-\mathrm{U} 1458 \mathrm{~A}-1 \mathrm{H}$ and $2 \mathrm{H}$ and $1.59 \mathrm{~g} / \mathrm{cm}^{3}$ in Core 4F. Average magnetic susceptibility (MS) was $0.66 \mathrm{SI}$, and two peaks were observed at depths of 1.1-1.4 and 9.5-9.7 m CSF-A. Low NGR counts and low GRA bulk density occur together and correspond to the coarser rudstone and vice versa for the carbonate sands. These trends may be due to lithological variations or to loss of water in the pore spaces of the coarser materials. $P$-wave velocity measurements were performed on the sandier portions of Cores $1 \mathrm{H}, 2 \mathrm{H}$, and $4 \mathrm{~F}$ and fluctuated between 1500 and $1800 \mathrm{~m} / \mathrm{s}$. Color reflectance was measured on the archive halves of split cores and did not show any clear trends. One moisture and density (MAD) sample was taken in each of Cores $1 \mathrm{H}, 2 \mathrm{H}$, and 4F. MAD bulk densities had the same values as corresponding GRA bulk densities, and MAD grain densities did not vary. Cores $1 \mathrm{H}$ and $2 \mathrm{H}$ have higher porosity ( $55 \%)$ than Core $4 \mathrm{~F}(47 \%)$.

Disturbance during drilling and coring resulted in sorting of the materials. Generally, the material becomes coarser downcore. However, cemented rudstones occurred at the tops of the cores. The physical properties reflect these changes in sediment size. However, we do not believe that these variations have stratigraphic significance.

\section{Site U1459}

Site U1459 lies in the northern part of the Perth Basin, about 1 nmi basinward of both Site U1458 and the Houtman-1 Well on the northern Rottnest shelf (James et al., 1999; Collins et al., 2014). It was originally intended as an alternate to Site U1458. The ship moved to Site U1459 after having difficulty coring the uppermost sediments at Site U1458 (see Operations in the Site U1458 chapter [Gallagher et al., 2017b]). Like Site U1458, Site U1459 is seaward of and downdip from the Houtman-Abrolhos main reef complex, which contains the most southerly tropical reefs in the Indian 
Ocean. Sites U1458 and U1459 comprise the southernmost sites of our latitudinal transect. The objectives for Site U1459 are the same as those for Site U1458. The evolution of the Houtman-Abrolhos reef complex is directly related to the path of the Leeuwin Current. Dating of sediments cored at Site U1459, coupled with seismic correlation, will provide insight into the pre-Quaternary history of these reefs and a long-term perspective on Leeuwin Current evolution at the tropical/subtropical boundary off Western Australia. In addition, it has been suggested that subsidence rates over $140 \mathrm{ky}$ were low compared to those of the Carnarvon Basin reefs (Collins and Testa, 2010). Subsidence analyses of the shelf wedge drilled at this site will extend this record and allow more precise modeling of dynamic subsidence along the western margin of Australia. An additional objective was to use any finer grained facies in this section to yield a Pliocene-Pleistocene record of the onset and variability of the southern Australian winter-dominated rainfall regime.

\section{Lithostratigraphy}

The lithostratigraphic units and their boundaries at Site U1459 (and all subsequent sites) are defined by changes in lithology (identified by visual core description and smear slide observations), physical properties, color reflectance $\left(\mathrm{L}^{*}, \mathrm{a}^{*}\right.$, and $\left.\mathrm{b}^{*}\right)$, X-ray diffraction (XRD), and petrographic thin section analyses. Site U1459 consists of seven lithostratigraphic units (Figure F9). The major lithologic differences between units are their texture, degree of lithification, fossil content, diagenetic features, and mineralogical components. Unit boundaries are defined based on the first occurrence of a new lithology downhole. The lithologic descriptions are based primarily on sediments recovered from Hole U1459B for 0-233.02 m CSF-A (i.e., to the bottom of Hole U1459B), augmented with observations from Holes U1459A and U1459C. Descriptions for strata deeper than $233.02 \mathrm{~m}$ CSF-A are from Hole U1459C. Seven lithostratigraphic units were defined:

- Unit I (Hole U1459A = 0-32.78 m CSF-A and Hole U1459B = 0-23.06 m CSF-A; lithified skeletal packstone to floatstone),

- Unit II (Hole U1459A = 32.78-42.93 m CSF-A and Hole $\mathrm{U} 1459 \mathrm{~B}=23.06-40.65 \mathrm{~m}$ CSF-A; unlithified mudstone to packstone interbedded with skeletal grainstone),

- Unit III (Hole U1459A = 43.93-70.75 m CSF-A and Hole U1459B = 40.65-95.60 m CSF-A; glauconitized unlithified to partially lithified packstone to grainstone with macrofossils),

- Unit IV (Hole U1459B = 95.60-139.20 m CSF-A; unlithified homogeneous packstone with glauconite),

- Unit V (Hole U1459B = 139.20-233.02 m CSF-A and Hole $\mathrm{U} 1459 \mathrm{C}=205.80-258.25 \mathrm{~m}$ CSF-A; dolomitic packstone with quartz and divided into two subunits):

- Subunit Va (Hole U1459B = 139.20-182.30 m CSF-A; unlithified packstone that includes a partially to fully lithified interval) and

- Subunit Vb (Hole U1459B = 182.30-233.02 m CSF-A and Hole U1459C = 205.80-258.25 m CSF-A; unlithified packstone with dolomite interbedded with lithified fine quartz sand),

- Unit VI (Hole U1459C = 258.25-296.40 m CSF-A; lithified beige to light brown/gray to brown dolostone), and

- Unit VII (Hole U1459C = 296.40-397.72 m CSF-A; lithified, chert-rich packstone and microcrystalline dark gray chert).

\section{Biostratigraphy and micropaleontology}

Holes U1459A and U1459B contain Pleistocene to late Miocene sediments, whereas the strata in Hole U1459C were determined to be of Oligocene to early middle Eocene age. E. huxleyi is present in Sample 356-U1459A-1F-CC, suggesting a Late Pleistocene to recent age, whereas the top of Pseudoemiliania lacunosa (Zone NN19, older than 0.44 Ma) is present in Holes U1459A (from Section 6F-2) and U1459B (Sample 5F-CC). The Pliocene/Pleistocene boundary in Sample 356-U1459B-12F-CC (64.25 m CSF-A) is marked by the presence of Discoaster surculus (>2.49 Ma). The top of the late Miocene $(5.59 \mathrm{Ma})$ was located by the presence of Discoaster neohamatus (33F-CC) and Discoaster quinqueramus (Sample 34F-CC; 165.26 m CSF-A) in Hole U1459B. Cores 46F and 47F are barren, but nannofossils in Core 48X indicate a middle Miocene age. Hole U1459C (Cores 2R through 10R) contains typical assemblages of early to late Miocene medium to large reticulofenestrids but no biostratigraphic markers. Deeper core catchers are barren of nannofossils or contain very rare Reticulofenestra haqii only. An earliest Oligocene (or older) age (>32.92 Ma) was inferred by the presence of Ericsonia formosa in Sample 19R-CC and Reticulofenestra umbilicus in Sample 20R-CC (293.14 m CSF-A). The presence of Cribrocentrum reticulatum in Sample 26R-CC (321.19 m CSF-A) confirms late Eocene age, and the bottom of Hole U1459C dates to the early middle Eocene based on the presence of Chiasmolithus grandis and E. formosa and absence of R. umbilicus.

The Pleistocene planktonic foraminifer Biozone Pt1a (0.61-1.93 $\mathrm{Ma}$ ) is between Cores 356-U1459A-5F and 10F (51.47 m CSF-A). Deeper than Core 356-U1459B-16F ( 83 m CSF-A), a Pliocene faunal assemblage is present (Biozone PL4), indicating an age of at least $3.47 \mathrm{Ma}$ (top of Dentoglobigerina altispira). Below the Pliocene, severe dolomitization prevented preservation of age-diagnostic fauna. Beginning again with Core 356-U1459C-20R (293.14 m CSF-A), preservation improves and planktonic foraminifers are present, but overall preservation remains (very) poor. The first identifiable faunas indicate an Oligocene age. Deeper than Sample 29R-CC (335.7 m CSF-A), a well-developed Eocene faunal assemblage is present and includes Subbotina gortanii, Subbotina eoceana, Globigerinatheka index, and Acarinina primitiva. These encompass Biozones E14-E9 ( 38-50 Ma). The bottom of Hole U1459C dates to the latest early Eocene (Biozone E7; first appearance datum of Acarinina bullbrooki and last appearance datum of Acarinina alticonica; 50.2 Ma).

The analyzed samples contain between $15 \%$ and $96 \%$ benthic foraminifers; Cibicides spp. and Cibicidoides spp. are the most common taxa. Four assemblages were defined by abundances of Textularia spp., Uvigerina spp., Bolivina spp., and epifaunal species:

- The first assemblage (0-46.51 m CSF-A) contains a range of shallow-water and deeper water warm to temperate species, such as Q. lamarckiana, Heterolepa bradyi, and Textularia spp. Larger benthic foraminifers, such as A. lessonii and Amphistegina lobifera are present between Cores 356-U1459A-5X and 10F (22.5-51.47 m CSF-A).

- The second assemblage (78.39-122.9 m CSF-A) is characterized by Uvigerina spp., particularly Uvigerina peregrina, Bolivina spp., and infaunal shallow-water (50-150 m) species.

- The third assemblage (165.26-238.85 m CSF-A) contains a lowdiversity fauna dominated by bolivinids.

- The fourth assemblage (287.11-387.68 m CSF-A) is composed almost entirely of epifaunal species.

In each sample, 1-41 species were observed. With the exception of the two uppermost core catcher samples from Hole U1459A (1F$\mathrm{CC}$ and $2 \mathrm{X}-\mathrm{CC}$ ), the preservation of benthic foraminiferal tests is 
Figure F9. Site U1459 summary showing core recovery (11 = drilled interval in Hole U1459C), lithostratigraphic units, age, magnetostratigraphy, biostratigraphy, NGR, and total spectral gamma ray (HSGR) wireline log. Gray bar = approximate depth of pipe in Hole U1459C; note the resulting dampened signal of gamma log in the upper $72 \mathrm{~m}$ WMSF. Age-depth model was produced from biostratigraphic datums based on calcareous nannofossils (black = Hole U1459B, blue $=$ Hole U1459C) (see Biostratigraphy and micropaleontology in the Site U1459 chapter [Gallagher et al., 2017c]). Sedimentation rates are shown for Holes U1459A-U1459C. Basal sedimentation rate for Hole U1459B is extended and calculated based on uppermost datum in Hole U1459C. Benthic foraminiferal assemblages were smoothed to generate this synthesis, resulting in slight differences from data presented in hole summaries. $\mathrm{BF}=$ benthic foraminifer, $\mathrm{PF}$ $=$ planktonic foraminifer, $\mathrm{NN}=$ calcareous nannofossil. IS = inner shelf, MS = middle shelf, OS = outer shelf, UB = upper bathyal. $\mathrm{cps}=$ counts per second.

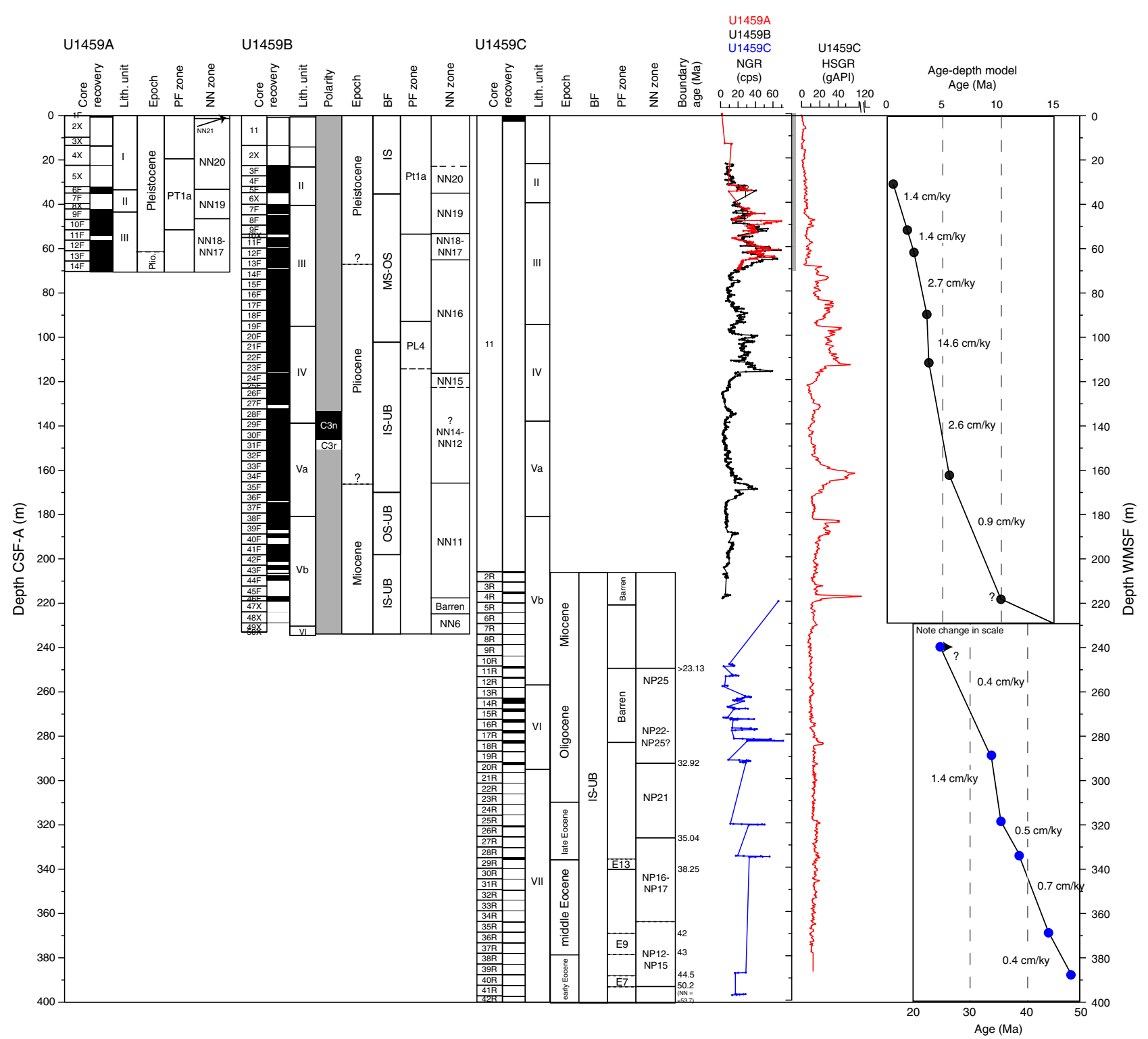

poor to very poor throughout Site U1459. Estimated paleobathymetry ranged from shallow/neritic environments $(\sim 50 \mathrm{~m})$ to $>500 \mathrm{~m}$.

Other fossil groups present included ostracods, bryozoa, worm casings, and pteropods.

\section{Geochemistry}

At Site U1459, 63 samples were analyzed for headspace gas content, 20 samples for IW geochemistry, 24 samples for carbonate, and 20 samples for total organic carbon (TOC) and total nitrogen (TN). Because of the nature of the recovered material, including chert and other lithified sediments in Hole U1459C, geochemical analyses were not performed except for carbonate and headspace gas measurements, which were made when feasible. The site is characterized by high percentages of calcium carbonate (mean value $=88 \mathrm{wt} \%$ ) and low TOC (mean value $=0.53 \mathrm{wt} \%$ ). Elevated salinity also characterizes the site, with values $>37$ deeper than $45 \mathrm{~m}$ CSF-A, reaching 50 in the interval from 120 to 195 m CSF-A. Overall, many of the geochemical parameters measured exhibit changes in trend or slope at $\sim 68 \mathrm{~m}$ CSF-A, where Sr sharply decreases from $\sim 300$ to $200 \mu \mathrm{M}$, or $\sim 120 \mathrm{~m} \mathrm{CSF}-\mathrm{A}$, where $\mathrm{Mg}$ and $\mathrm{SO}_{4}{ }^{2-}$ both reach maximum values of 65 and $40 \mathrm{mM}$, respectively.

\section{Paleomagnetism}

Paleomagnetic investigations at Site U1459 included routine measurements and partial demagnetization of natural remanent magnetization (NRM) of archive-half core sections and selected 
discrete samples from working-half sections. Rock magnetic experiments, including extended demagnetization sequences, were also conducted on discrete samples. NRM intensity values from the archive half range from $10^{-2}$ to $10^{-5} \mathrm{~A} / \mathrm{m}$ after alternating field (AF) demagnetization peak fields of 20 and $30 \mathrm{mT}$. Two distinct intervals emerged from the otherwise scattered directional data: (1) three peaks of negative magnetic inclination (corresponding to normal polarity) and intensity values between $\sim 130$ and $140 \mathrm{~m} \mathrm{CSF-A} \mathrm{and}$ (2) a peak of positive magnetic inclination (reversed polarity) between 145 and $170 \mathrm{~m}$ CSF-A. Constraints from biostratigraphic datums suggest these features are older than $3.7 \mathrm{Ma}$ and are thus tentatively correlated with Subchrons C2Ar (3.596-4.187 Ma) and C3n (C3n.1n [4.187-4.3 Ma], C3n.2n [4.493-4.631 Ma], and C3n.3n [4.799-4.896]). Discrete sample results are generally comparable to archive-half intensity and inclination values. Uncertainties associated with determining the characteristic paleomagnetic directions and magnetic mineralogy are amplified by the pervasive diagenesis throughout the sediments.

\section{Physical properties}

Physical properties measurements were carried out using the WRMSL, NGR sensor, $P$-wave velocity caliper, and discrete sampling. Thermal conductivity was also measured in several sections and varied between 1.0 and $1.3 \mathrm{~W} /(\mathrm{m} \cdot \mathrm{K})$. Bulk density was determined using both GRA and MAD methods (see Physical properties in the Expedition 356 methods chapter [Gallagher et al., 2017a]). These two methods yielded consistent increases in density with depth to $160 \mathrm{~m}$ CSF-A, below which it becomes variable. The increase may reflect increasing diagenesis and generation of dolomite from calcite. The MS of the recovered sediments is relatively low, with most readings ranging between -2 and 4 SI. The trend of MS values rises from 80 to $140 \mathrm{~m}$ CSF-A, where there is an overall decrease in NGR. NGR also shows several distinct peaks at 48.5, 61, and $64.5 \mathrm{~m}$ CSF-A in Hole U1459A and 65, 100, and $170 \mathrm{~m}$ CSF-A in Hole U1459B. These peaks proved to be of value for stratigraphic correlation (Figure F9). $P$-wave sonic velocities measured shallower than $200 \mathrm{~m}$ CSF-A on whole-round cores and discrete samples compare well. In the upper $200 \mathrm{~m}$, velocities are typically $<2000$ $\mathrm{m} / \mathrm{s}$. Deeper than $200 \mathrm{~m}$ CSF-A, $P$-wave velocities show high values (up to $6257 \mathrm{~m} / \mathrm{s}$ ) because they were obtained from lithified sediment, including cherts and dolomitic cobbles. Reflectance spectroscopy and colorimetry data display high-amplitude variability, consistent with notable color changes in the sediments. Porosity is generally high, ranging between $50 \%$ and $60 \%$ to $120 \mathrm{~m}$ CSF-A. Further downcore, porosity decreases to a minimum of $35 \%$ at $208.5 \mathrm{~m}$ CSF-A.

\section{Downhole logging}

Downhole measurements in Hole U1459C were successful and consisted of runs with the triple combination (combo) and the Formation MicroScanner (FMS)-sonic tool strings. The triple combo string was deployed with a reduced configuration (without the porosity, density, and resistivity tools). The triple combo measured borehole width, NGR, and MS from 72.2 (the end of the drill pipe) to $390 \mathrm{~m}$ wireline log matched depth below seafloor (WMSF). Two up and down passes were made with this tool. Borehole conditions prevented the FMS-sonic tool from passing deeper than $288 \mathrm{~m}$ WMSF. The wireline NGR agrees well with the data from wholeround cores from Hole U1459B: many peaks and troughs from Hole U1459B cores were reproduced by the downhole logs from Hole
U1459C (Figure F9). These data show that the important NGR peaks in the upper $150 \mathrm{~m}$ of Hole U1459C were mainly driven by variations in $U$ content. The NGR peak in the downhole logging data at $160 \mathrm{~m}$ WMSF corresponds to the NGR peak in Hole U1459B cores at $168 \mathrm{~m}$ CSF-A and results from increased concentrations of both $\mathrm{U}$ and $\mathrm{K}$. The NGR peak in the downhole logging data at $185 \mathrm{~m}$ WMSF corresponds to the NGR peak in Hole U1459B cores at 192 $\mathrm{m}$ CSF-A and is the result of increased concentrations of Th and $\mathrm{K}$, which may be consistent with an increase in detrital mineral input. Downhole MS confirmed the increasing trend in susceptibility between 75 and $145 \mathrm{~m}$ WMSF that was also observed in core measurements from the WRMSL. However, between 145 and 155 m CSF-A the core-based MS data from Hole U1459B show a rapid decrease that is not observed in the downhole logging data. In contrast, the latter continue to increase gradually with depth between 145 and $210 \mathrm{~m}$ WMSF, although a correlation of meter- to decimeter-scale variations between the core-based MS data from Hole U1459B and wireline $\mathrm{K}$ concentration data from Hole U1459C was noted. FMS images reveal differences in resistivity that reflect changes in textures and lithology through the logged interval (112-286 m WMSF). The image quality is high deeper than $\sim 250 \mathrm{~m}$ WMSF but poor at shallower depths because of poor contact with the borehole walls. The spacing between alternations of high- and low-resistivity values deeper than $250 \mathrm{~m}$ WMSF ranges from several decimeters to $2 \mathrm{~m}$, with thin (several decimeters) resistive layers interbedded within broader (1-2 m) more conductive areas. Between 100 and $200 \mathrm{~m}$ WMSF, sonic velocities from Hole U1459C tend to be a few hundred meters per second higher than sonic velocities obtained from discrete measurements with the $P$-wave caliper from Hole U1459B. At $216 \mathrm{~m}$ WMSF, downhole sonic velocities peak at 3228 $\mathrm{m} / \mathrm{s}$. This observation is in agreement with the discrete $P$-wave velocity measurements made on a lithified dolomitic cobble from Section 356-U1459C-4R-1 (215.34 m CSF-A). These results suggest that the retrieved dolomitic cobbles can be considered representative of the formation in this interval. Between 217 and $245 \mathrm{~m}$ WMSF, downhole sonic velocities are relatively constant with variations between 2150 and $2400 \mathrm{~m} / \mathrm{s}$. In this interval, discrete measurements were only possible on lithified cobbles, and those sonic velocities exceeded $5000 \mathrm{~m} / \mathrm{s}$. Therefore, these cobbles should not be considered representative of the cored sediments.

\section{Stratigraphic correlation}

Three holes were cored at Site U1459. The highest recovery occurred in Hole U1459B and ranged from Late Pleistocene to middle Miocene in age. Unfortunately, recovery in Hole U1459A was not sufficient to allow for either detailed analysis or a high-resolution correlation between Holes U1459A and U1459B. Hole U1459C extends into the Eocene. Wireline NGR data were generated from Hole U1459C, but the very low core recovery limited the ability to correlate between Hole U1459C lithology and the wireline log. Sedimentation rates are between 0.4 and $1.4 \mathrm{~cm} / \mathrm{ky}$ in the Paleogene, relatively low in the Miocene $(<1 \mathrm{~cm} / \mathrm{ky})$, very high during the middle Pliocene (nearly $15 \mathrm{~cm} / \mathrm{ky}$ ), and $>1 \mathrm{~cm} / \mathrm{ky}$ in the Pleistocene (Figure F9).

\section{Site U1460}

Site U1460 lies in the northern part of the Perth Basin, about 18 nmi north of Site U1459 and $\sim 150 \mathrm{~m}$ from the adjacent Morangie-1 Well on the Carnarvon ramp (James et al., 1999; Collins et al., 2014). The site is north of the Houtman-Abrolhos main reef complex, 
which contains the most southerly tropical reefs in the Indian Ocean. Site U1460 is at the northern edge of the modern winterdominated rainfall zone of southwestern Australia and was targeted to chart the timing of this regime; prior to drilling this site we suggested that it was not likely to yield an orbital-scale climate record because of slope erosional processes. However, coring recovered a $300 \mathrm{~m}$ thick late Pliocene to Pleistocene record that may indeed reveal orbital-scale climate variability and complement the record at Site U1461. Site U1460 is south of a climatic divide between the Australian monsoon-dominated north and the westerly winddriven, winter rainfall-dominated south. The site is near the southern end of our north-south latitudinal transect and also provides a shelf to shelf-edge record of the tropical-subtropical transition related to Leeuwin Current activity. Site U1460 is influenced by the anticlockwise, colder West Australian Current gyre; the relative influence of this gyre versus the Leeuwin Current produces variations in paleoproductivity that may be documented over millions of years. Subsidence rates in this region are estimated to be signifi- cantly less than in the Carnarvon Basin further north because of variations in mantle dynamic subsidence between the Perth and Carnarvon Basins. Paleobathymetric analyses should produce the first detailed >1 My subsidence record for this part of the Western Australian margin, where previous subsidence estimates only extend to $125 \mathrm{ka}$ (Collins and Testa, 2010).

\section{Lithostratigraphy}

Site U1460 consists of two lithostratigraphic units, with three subunits in the upper unit (Figure F10). Unit boundaries are defined by the first occurrence of a new lithology downhole. Subunits are distinguished primarily by differences in the most abundant fossils, diagenesis, and mineralogical components. Lithified intervals characterized by authigenic mineralization, and interpreted as hardgrounds, define the boundaries between subunits. Lithologic descriptions are based on sediments recovered from Holes U1460A (0-300.08 m CSF-A) and U1460B (0-306.65 m CSF-A):

Figure F10. Site U1460 summary showing core recovery, lithostratigraphic units, age, magnetostratigraphy, biostratigraphy, and NGR. For Hole U1460B, only limited biostratigraphy (Cores $65 \mathrm{~F}$ through $68 \mathrm{~F}$ ) and no magnetostratigraphic analyses were performed, so age-depth model for both holes is presented as a composite, resulting in an inconsistency in planktonic foraminiferal datums and associated sedimentation rates from $\sim 300$ to $280 \mathrm{~m}$ CSF-A. Note the different sedimentation rates for planktonic foraminiferal (blue) and calcareous nannofossil (green) datums. Open circles = depth for D. altispira in Holes U1460A (upper point at $279.36 \mathrm{~m} \mathrm{CSF-A)}$ ) and U1460B (lower point at $298.92 \mathrm{~m} \mathrm{CSF-A)} \mathrm{(see} \mathrm{Biostratigraphy} \mathrm{and} \mathrm{micropaleontology} \mathrm{in} \mathrm{the} \mathrm{Site} \mathrm{U1460} \mathrm{chapter} \mathrm{[Gallagher} \mathrm{et}$ al., 2017d]). Benthic foraminiferal assemblages were smoothed to generate this synthesis, resulting in slight differences from data presented in hole summaries.

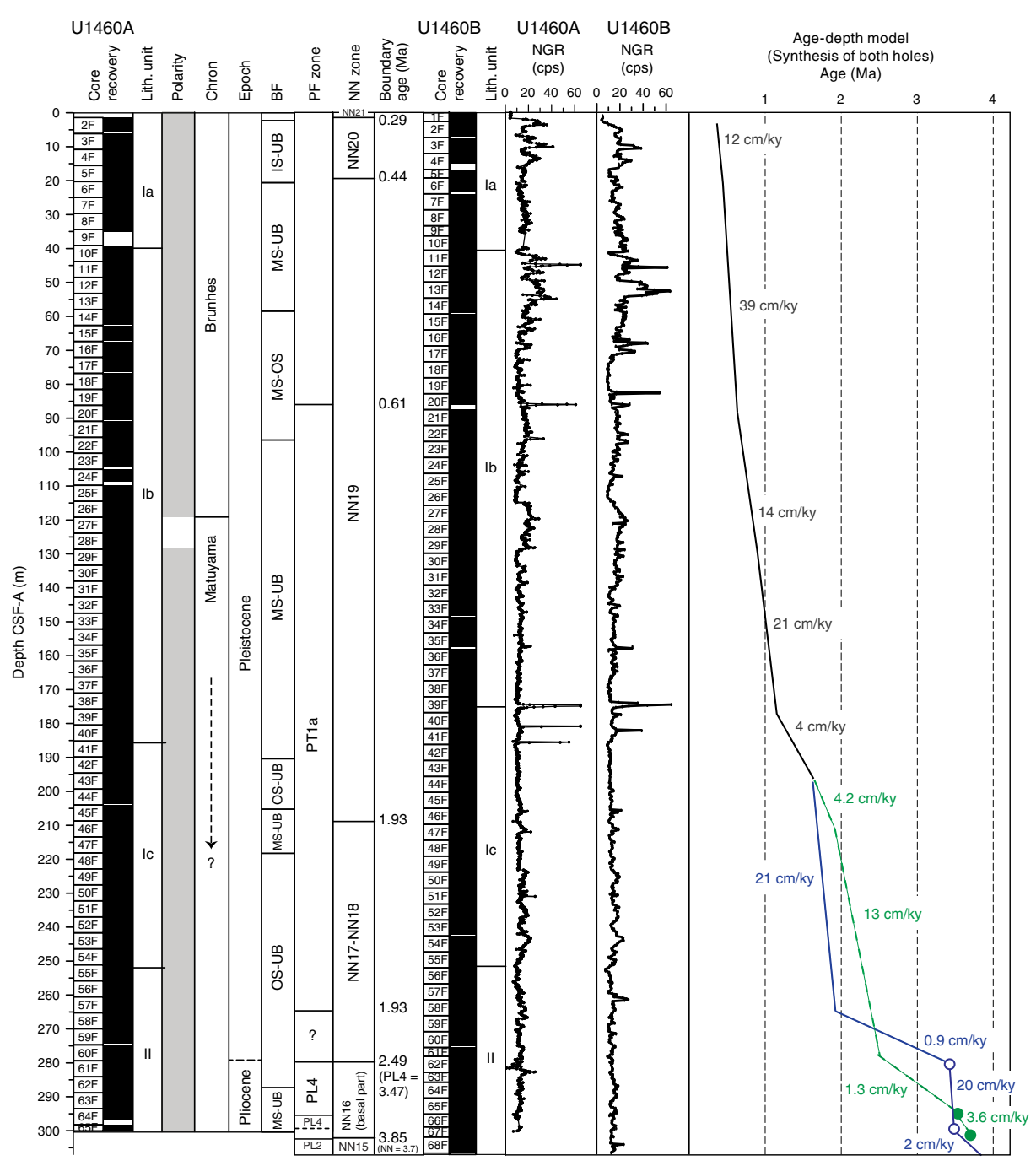


- Unit I encompasses most of Holes U1460A (0-252.70 m CSF-A) and U1460B (0-252.00 m CSF-A) and consists of predominantly unlithified to partially lithified skeletal packstone with wackestone and grainstone intervals. This unit is divided into three subunits based on the abundances of macrofossils, sponge spicules, and degree of diagenesis:

- Macrofossils are concentrated in Subunit Ia (Hole U1460A = 0-44.90 m CSF-A and Hole U1460B = 0-44.94 m CSF-A),

- Sponge spicules are concentrated in Subunit Ib (Hole $\mathrm{U} 1460 \mathrm{~A}=44.90-174.53 \mathrm{~m}$ CSF-A and Hole U1460B = 44.94-173.36 m CSF-A), and

- Subunit Ic (Hole U1460A = 174.53-252.70 m CSF-A and Hole U1460B = 173.36-252.00 m CSF-A) has a high authigenic glauconite and increased dolomite and macrofossil content.

- Unit II (Hole U1460A = 252.70-300.08 m CSF-A and Hole $\mathrm{U} 1460 \mathrm{~B}=252.00-306.65 \mathrm{~m}$ CSF-A) consists of unlithified to partially lithified packstone, mudstone, and wackestone. Unit II is defined by the first appearance of a mass-wasting deposit. The mass-wasting deposits in Unit II, characterized by graded or contorted beds, are interpreted as turbidity current deposits, slumping sediments, and debris flows.

\section{Biostratigraphy and micropaleontology}

A total of 54 smear slides were examined for calcareous nannofossil biostratigraphic marker species and common taxa. Calcareous nannofossils are common to dominant and show overall good preservation in the (predominantly) packstone sediments recovered at Site U1460. The nannofossil assemblages are dominated by placolith-bearing members of the Noelaerhabdaceae family, most notably by small $(<4 \mu \mathrm{m})$ Gephyrocapsa spp. and Reticulofenestra spp. The early Pleistocene-late Pliocene marker species Discoaster brouweri (top at $1.93 \mathrm{Ma}$ ) is rare from Sample 356-U1460A-45F-CC (208.85 m CSF-A) to the base of Hole U1460A (65F-CC [300.08 m CSF-A]). The top occurrences of Sphenolithus spp. in Samples 63FCC (293.45 m CSF-A) and 356-U1460B-65F-CC (295.04 m CSF-A) indicate that the bases of both holes are of middle Pliocene age.

Planktonic foraminifer preservation and abundance is significantly better at Site U1460 than at Sites U1458 and U1459. Biozone Pt1a (0.61-1.93 Ma; top of G. tosaensis and base of Globorotalia truncatulinoides) is between Samples 356-U1460A-19F-CC and 57F-CC (86.5 and 265.2 m CSF-A). Deeper than Sample 60F-CC (279.3 m CSF-A), a Pliocene assemblage is present (Biozone PL4) that indicates a minimum age of $3.47 \mathrm{Ma}$ (top of $D$. altispira). The bottom of Hole U1460B (68F-CC [306.65 m CSF-A]) is within Biozone PL2 (top of Globorotalia margaritae) and is based on the presence of G. crassaformis. Site U1460 has an oldest age of 4.3 Ma (base of Biozone PL2) (Figure F10).

The samples contain between $13 \%$ and $63 \%$ benthic foraminifers; Cibicides spp. and Cibicidoides spp. are the most common taxa. Four assemblages can be identified based on the abundances of $U$. peregrina, Siphogenerina raphana, Bolivina spp., Trifarina spp., Cibicides spp., and Cibicidoides spp. Samples contain 7-35 species. Except for the uppermost three samples from Hole U1460A (1F-CC through 9F-CC [2.13-35.6 m CSF-A]), preservation is poor and affected by fragmentation and abrasion. The proportion of planktonics suggest outer shelf to upper slope (100-500 m) paleodepths.

\section{Geochemistry}

At Site U1460, 64 samples were analyzed for headspace gas content, 31 samples ( $5 \mathrm{~cm}$ whole rounds) for IW geochemistry, and 31 samples for TOC, carbonate, and TN. In general, elevated salinity characterizes the site, with values of 35 at the top, increasing with depth to 61 at $287 \mathrm{~m}$ CSF-A. Increasing trends of most of major elements in the IW samples are reflected in the salinity record. However, K decreases slightly downhole from 10.9 to $8.2 \mathrm{mM}$, possibly reflecting the decreasing clay content in the deeper sediments. Silica is $381 \mu \mathrm{M}$ at the surface and increases to a maximum value of $1683 \mu \mathrm{M}$ at $137 \mathrm{~m}$ CSF-A. From 137 to $193 \mathrm{~m}$ CSF-A, silica concentration decreases to $\sim 1200 \mu \mathrm{M}$, followed by relatively stable values to the bottom of Hole U1460A. Variations in elemental silicon might imply the importance of biogenic silica in these sediments, related to the interval of high sponge spicule content (lithostratigraphic Subunit Ib). Furthermore, the site is also characterized by high percentages of calcium carbonate (mean value $=90 \mathrm{wt} \%$ ) and low TOC (mean value $=0.48 \mathrm{wt} \%)$ and $\mathrm{TN}$ ( mean value $=0.03 \mathrm{wt} \%$ ). Relatively low calcium carbonate content seems to be related to the section with higher sponge spicule content.

\section{Paleomagnetism}

Paleomagnetic investigations at Site U1460 included routine measurements and partial AF demagnetization of NRM of archivehalf core sections and selected discrete samples from working-half sections of Hole U1460A. Hole U1460B was not measured since lithologic similarities to Hole U1460A indicated overlapping stratigraphy. Isothermal remanent magnetization (IRM) and backfield IRM curves from discrete samples provide coercivity of remanence values ranging from 40.7 to $67.0 \mathrm{mT}$. Further cumulative log-Gaussian analysis indicates three components-two of them providing the main contribution to the IRM pattern and exhibiting low magnetic coercivity behavior, which are parameters indicative of the presence of magnetite and/or titanomagnetite. A third component presented high-coercivity behavior $\left(B_{1 / 2}=263 \mathrm{mT}\right)$, which suggests the presence of hematite and/or goethite. Residual NRM intensity values range from $10^{-2}$ to $10^{-5} \mathrm{~A} / \mathrm{m}$ after $\mathrm{AF}$ demagnetization with peak fields of $30 \mathrm{mT}$. Based on nannofossil-based age constraints (0.91 Ma at $129 \mathrm{~m} \mathrm{CSF-A),} \mathrm{the} \mathrm{observed} \mathrm{polarity} \mathrm{reversal} \mathrm{at} \sim 120 \mathrm{~m}$ may represent Subchron C1r.1r (0.988-0.781 Ma) near the Brunhes/Matuyama boundary (Subchron C1n/C1r.1r) at $0.781 \mathrm{Ma}$.

\section{Physical properties}

Core recovery at Site U1460 was very high (97\%), so measurements were able to demonstrate clearly how physical properties parameters vary with depth. MS shows large-scale trends that are similar between both holes and between both the WRMSL and Section Half Multisensor Logger (SHMSL). All MS records show a general decrease of $\sim 2$ SI from the top to $180-200 \mathrm{~m}$ CSF-A. From that depth to the bases of both holes ( 300 m CSF-A), an increase of 1$2 \mathrm{SI}$ is observed in all MS records. However, meter-scale variability is not consistent from hole to hole and between the WRMSL and SHMSL. The NGR data are characterized by strong variations with an amplitude up to 30 counts/s that can be correlated between the holes at vertical scales of tens of meters, despite measuring at different resolutions between Holes U1460A $(10 \mathrm{~cm})$ and U1460B (20 $\mathrm{cm})$. Moreover, hardground and condensed layers produced major peaks in the NGR data (more than 140 counts/s), facilitating accurate correlation of these layers between holes (Figure F10). Porosity decreases from $50 \%-60 \%$ at the top to $39 \%-49 \%$ at the bases of both holes. Correlation between decreasing porosity and increasing $P$ wave velocities $(R=0.405)$, bulk densities $(R=0.88)$, and thermal conductivities $(R=0.67)$ suggests that these variations may be, in part, due to compaction. In situ formation temperature measure- 
ments were made in Hole U1460B to complement the thermal conductivity measurements. This allowed for calculation of the geothermal flux $\left(62 \mathrm{~mW} / \mathrm{m}^{2}\right)$.

\section{Stratigraphic correlation}

Attempts to correlate Holes U1460A and U1460B were made using NGR data; the core logger was run at $10 \mathrm{~cm}$ resolution on Hole U1460A and $20 \mathrm{~cm}$ resolution on Hole U1460B cores. The GRA data collected on the Special Task Multisensor Logger and b* collected on the SHMSL were also used for correlation purposes. Correlations were further constrained by the core photos and lithologic descriptions, particularly of debris flows and hardgrounds. The lithologic descriptions show considerable variation across the two holes, especially in the lower part of the section where debris flows were found. Unfortunately, the fact that only two holes were cored, both using the half-length advanced piston corer (HLAPC) system, did not allow for generation of a complete splice, although the approximate correlation is useful for Site U1460 sampling.

Sedimentation rates are generally low in the Pliocene and high in the Pleistocene (Figure F10), although there is some divergence in rates calculated from calcareous nannofossil and planktonic foraminiferal datums. Sedimentation rates produced from planktonic foraminiferal datums indicate moderate to high rates in Pliocene Zones PL2 (2 cm/ky; Hole U1460B) and PL4 (20 cm/ky; Hole U1460A). Zone PL4 correlates with a zone of mass wasting in lower Unit II. In contrast, calcareous nannofossil-based rates associated with glauconite-rich zones of mass wasting in Unit II are low (between 1.3 and $3.6 \mathrm{~cm} / \mathrm{ky})$. Just above this level and just above the Pliocene/Pleistocene boundary $(\sim 280-265 \mathrm{~m}$ CSF-A in Hole U1460A), low planktonic foraminifer-derived sedimentation rates $(0.9 \mathrm{~cm} / \mathrm{ky})$ occur at the change from mud-rich wackestone to a more sandy packstone and indicate reduced deposition (or a possible unconformity). Sedimentation rates are generally very high throughout the Pleistocene $(12-39 \mathrm{~cm} / \mathrm{ky})$ except for one low sedimentation rate interval ( 208.85-176.24 $\mathrm{m}$ CSF-A) near the base of Zone NN19 (1.93-1.14 Ma). The unit terminates at a hardground around the base of Core 356-U1460A-38F ( 177 m CSF-A).

\section{Site U1461}

Site U1461 is $100 \mathrm{~km}$ northwest of Barrow Island in the NCB, $\sim 150 \mathrm{~m}$ from the West Tryal Rocks-2 Well. It is on the edge of an outer shelf ramp (James et al., 2004). The seabed in the region is poorly sorted carbonate-rich ( $>90 \%$ ) sediment made up of bioclastic gravel, sand, and mud (Jones, 1973; James et al., 2004). Coring at Site U1461 targeted a $1 \mathrm{~km}$ thick outer shelf to upper slope carbonate wedge that onlaps (because of basin-wide subsidence) a regional top Miocene surface.

The primary objective of Site U1461 was to obtain a $>4$ My orbital-scale record of climate variability and monsoonal history comparable in resolution to other global climate proxy records. One benefit of coring this shelf-margin setting is that terrigenous clay and terrestrial palynomorphs should be abundant, delivered by fluvial outflow during the rainy season (van der Kaars and De Deckker, 2003). This location is also close to the southern boundary of Australian monsoonal influence and can be used to chart its latitudinal variability. Marine microfossil paleoproductivity analyses at this site should also reveal the dominance of the West Australian Current over the Leeuwin Current during glacial periods, when the Australian monsoon is thought to have been weak (Gallagher et al., 2014b). There are intervals in this section that consist of plankton ooze
(Gallagher et al., 2009) deposited at upper to middle slope paleodepths. Therefore, combining $\mathrm{C} / \mathrm{O}$ and $\mathrm{Mg} / \mathrm{Ca}$ analyses of microfossils from Site U1461 should produce a Pliocene-Pleistocene obliquity- (or even precession-) scale record that can be directly compared and correlated to the LR2004 stack (Lisiecki and Raymo, 2005) for chronostratigraphic and paleoceanographic analyses. Site U1461 is downdip from a drowned reef on a paleoshelf edge (Gallagher et al., 2014b). By dating the reflectors and correlating them updip, it will be possible to constrain the age of onset of this reef and other reefs regionally. Furthermore, downslope-transported reefal or shelf detritus into this section will enable analysis of reef and ramp development in response to variable sea level.

\section{Lithostratigraphy}

The lithostratigraphy of Site U1461 is divided into four units, with six subunits in Unit II (Figure F11):

- Unit I (Hole U1461A = 0-11.00 m CSF-A, Hole U1461B = 0$11.30 \mathrm{~m}$ CSF-A, and Hole U1461C $=0-11.40 \mathrm{~m}$ CSF-A) consists of mainly unlithified homogeneous olive-gray to brown to greenish gray packstone with benthic foraminifers and bivalves. - Unit II (Hole U1461A = 11.00-284.71 m CSF-A, Hole U1461B = 11.30-466.40 m CSF-A, Hole U1461C = 11.40-443.88 m CSF-A, and Hole U1461D = 455.00-466.98 m CSF-A) is divided into six subunits (IIa, IIb, IIc, IId, IIe, and IIf in descending order). In Unit II, all subunits except Subunit IIa consist of two intervals: (1) an upper coarser grained, darker colored, thicker interval of unlithified dark greenish gray to olive-gray packstone/wackestone and (2) a lower, finer grained, light-colored, thinner interval of unlithified, homogeneous, cream to light gray mudstone. The exception, Subunit IIa, consists entirely of light-colored mudstone/wackestone. Throughout Unit II, the lower interval of each subunit is always thinner than the upper interval. These upper and lower intervals are further distinguished by differences in degree of bioturbation and abundances of macrofossils and peloids and, in the case of Subunit IIf, the presence of lowangle cross-stratification and normal grading. Ooids occur in Subunits IIa and IIb.

- Unit III (Hole U1461B = 466.40-877.74 m CSF-A and Hole $\mathrm{U} 1461 \mathrm{D}=466.98-992.88 \mathrm{~m}$ CSF-A) consists of lithified wackestone ranging in color from greenish gray to olive-gray. Bioturbation is common throughout the unit, and burrows are often filled with coarse sand. Foraminifers are common, whereas fragments of bivalves and gastropods are rare. In the lower half of Unit III there are a variety of sedimentary contacts, ranging from sharp to wavy, gradational, and scoured. The occurrence of these contacts often coincides with numerous sedimentary features, including parallel lamination, thin bedding, normal grading, load casts, slump folds, and intraclasts. Pyrite is also present in the lower half of Unit III as disseminated grains and nodules.

- Unit IV (Hole U1461D = 992.88-1088.92 m CSF-A) consists of lithified, light greenish gray, fine sand-sized packstone (interbedded with wackestone with mud-sized grains) that grades into creamy gray packstone with coarse sand-sized grains (interbedded with packstone with coarser sand-sized grains). Near the base of the unit, the lithology transitions back to light greenish gray packstone with fine sand-sized grains, interbedded with wackestone with mud-sized grains. Bioturbation, benthic foraminifers, and pyrite are more abundant in muddy intervals. Bedding contacts are sharp. Planar laminae and normal grading are present in the coarser grained intervals. 
Figure F11. Site U1461 summary showing core recovery (11 = drilled interval in Hole U1461D), lithostratigraphic units, age, magnetostratigraphy, biostratigraphy, NGR, and Hole U1461D wireline HSGR. Gray bar = casing depth; note the resulting dampened signal of the gamma log. Biostratigraphic zone boundary ages are shown. Age-depth model was produced from select biostratigraphic datums (see Table T6 in the Site U1461 chapter [Gallagher et al., 2017e]) color coded by hole (solid circles = calcareous nannofossil, open circles = planktonic foraminifer). Sedimentation rates assume a linear sedimentation rate between datums. Position of the unconformity (wavy line) in the Miocene is determined by lithologic change in Section 356-U1461D-51R-CC. Benthic foraminiferal assemblages were smoothed to generate this synthesis, resulting in slight differences from data presented in hole summaries.

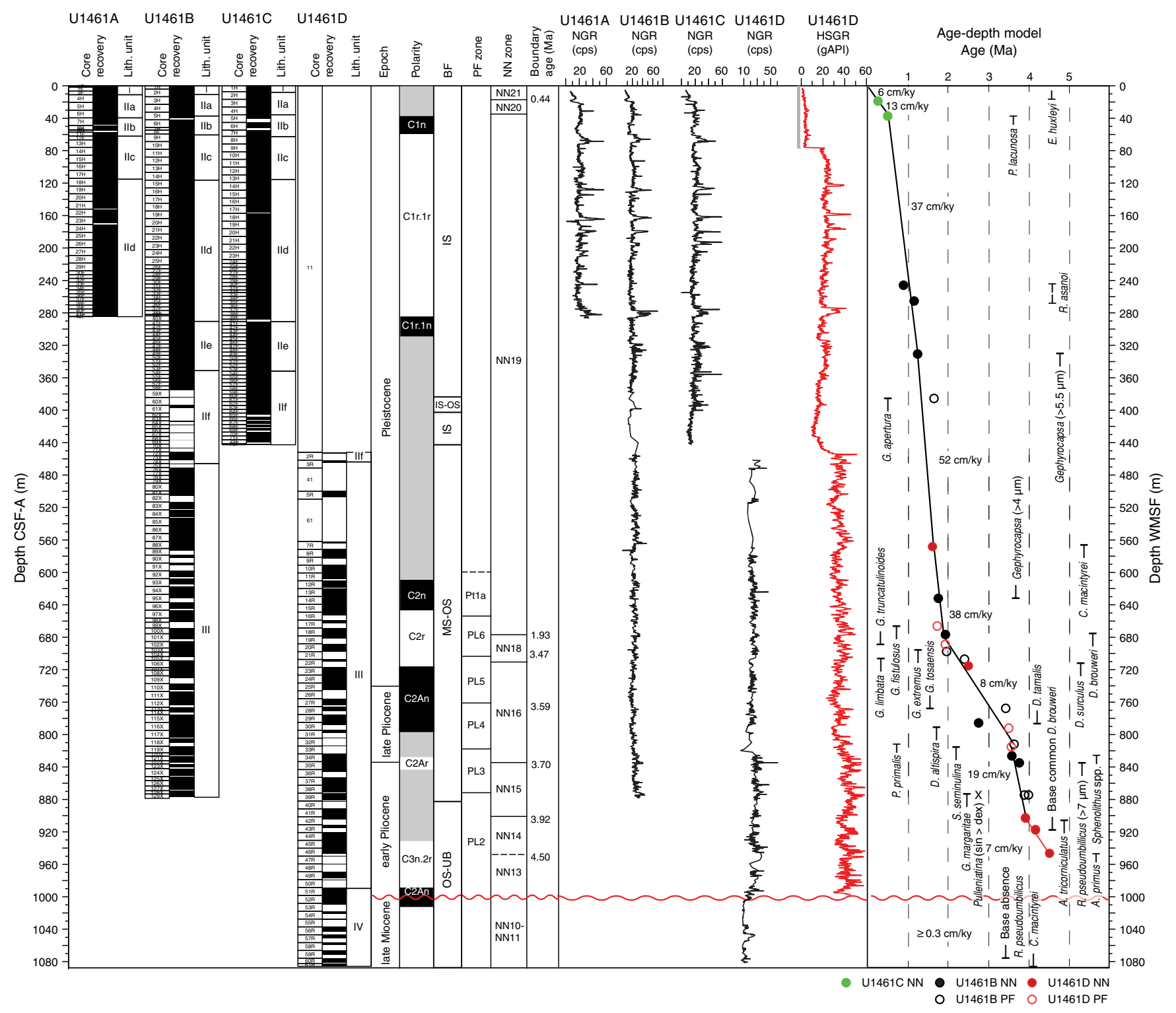

\section{Biostratigraphy and micropaleontology}

Core catcher samples from Site U1461 were analyzed at $20 \mathrm{~m}$ resolution through Holes U1461A, U1461B, and U1461D. In Hole U1461C, sampling focused on the uppermost $53 \mathrm{~m}$ (mudline and Cores $1 \mathrm{H}$ through $6 \mathrm{H}$ ) and deeper than $\sim 370 \mathrm{~m} \mathrm{CSF-A} \mathrm{(57F-CC}$ through 73F-CC [443.88 m CSF-A]). The bottoms of Holes U1461A (284.71 m CSF-A) and U1461C (443.88 m CSF-A) are of early Pleistocene age (base of Zone NN19, <1.93 Ma). The sediments retrieved from Hole U1461B (a total of 129 cores) are of PliocenePleistocene age, with the bottom (877.74 m CSF-A) estimated to be older than $4.08 \mathrm{Ma}$ (based on planktonic foraminifers). Hole U1461D was analyzed from $456.36 \mathrm{~m}$ CSF-A to total depth $(1088.92$ $\mathrm{m}$ CSF-A). The abundance and preservation of calcareous nannofossils and planktonic foraminifers decrease markedly from Sample
356-U1461D-52R-CC (1008.3 m CSF-A) downhole with possible reworking, suggesting a probable unconformity. The bottom of Hole U1461D dates to the middle to late Miocene $(<12.38-8.79 \mathrm{Ma}$; based on nannofossils) (Figure F11).

Samples from Holes U1461A-U1461D contain between 5\% and 91\% benthic foraminifers with Cibicides spp. and Cibicidoides spp. as the most common taxa. Six assemblages were identified based on benthic abundances:

- Assemblage 1: A. lessonii, Hyalinea baltica, and Sahulia barkeri

- Assemblage 2: Elphidium spp.

- Assemblage 3: Neoeponides margaritifer

- Assemblage 4: Uvigerina spp.

- Assemblage 5: Nodosaria spp. and Stilostomella spp.

- Assemblage 6: Globocassidulina subglobosa 
Seven to 63 species are present in the samples. Preservation varies from moderate to poor throughout the site and was affected by fragmentation and abrasion.

\section{Geochemistry}

At Site U1461, 140 samples were analyzed for headspace gas content, 38 samples (5-15 cm whole rounds) for IW geochemistry, and 38 samples for TOC, carbonate, and TN. IW samples were not collected in Holes U1461C and U1461D. Hole U1461C recovered a section previously sampled in Holes U1461A and U1461B, and the lithology at the bottom of Hole U1461B (877.74 m CSF-A) yielded insufficient pore water, so there was no possibility of obtaining sufficient amounts of pore water from deeper intervals in Hole U1461D. In general, elevated salinity characterizes the site, with a value of 35 at the top, increasing gradually with depth to 137 at 870 $\mathrm{m}$ CSF-A. Coincident increasing trends with depth of bromide, chloride, and sodium in the IW samples are consistent with the salinity record. Increasing trends of alkalinity, $\mathrm{pH}$, and ammonium and a decreasing trend of sulfate indicate a reduction zone in the upper $100 \mathrm{~m}$ of the site. Finally, the site is characterized by high percentages of calcium carbonate (mean value $=\sim 80 \mathrm{wt} \%$ ) and low TOC $($ mean value $=0.9 \mathrm{wt} \%)$ and TN (mean value $=0.04 \mathrm{wt} \%)$.

\section{Paleomagnetism}

Paleomagnetic investigations focused on NRM and partial AF demagnetization measurements. To address some technical issues (flux jumps) related to the superconducting rock magnetometer (SRM) measurements from Holes U1461B and U1461C, a representative group of discrete samples underwent AF demagnetization and were compared to the SRM directional data to provide more reliable magnetostratigraphic interpretations. This issue was fixed for Hole U1461D archive-half section measurements. For Holes $\mathrm{U} 1461 \mathrm{~B}$ and U1461C, comparisons between results from the archive-half and discrete sample measurements indicate normal (negative) overprint until 30-50 mT demagnetization steps, which could not be fully cleaned after SRM AF demagnetization procedures (up to $20 \mathrm{mT}$ ). IRM and backfield IRM acquisition curves were also carried out to investigate rock magnetism properties. Most samples seem to reach saturation IRM (SIRM) between 100 and $300 \mathrm{mT}$, which is indicative of a wide range of magnetic carriers and was verified for a narrow range of coercivity of remanence values (45-50 $\mathrm{mT})$. Complementary XRD measurements indicated, for at least one sample from Hole U1461B, the presence of low- (e.g., magnetite, titanomagnetite, and maghemite), intermediate- (e.g., greigite), and high- (e.g., hematite, greigite, and goethite) coercivity phases. Magnetostratigraphy for Hole U1461C indicated the Brunhes/Matuyama boundary (0.781 Ma) is between 45 and $65 \mathrm{~m} \mathrm{CSF}-\mathrm{A}$ and the Jaramillo Subchron (0.988 Ma) is between 281 and $316 \mathrm{~m}$ CSF-A (Figure F11). Hole U1461D magnetostratigraphic data indicates a succession of magnetozones in a good agreement with biostratigraphic datums, suggesting the Matuyama/Gauss (2.581 Ma) and Gauss/Gilbert (3.596 Ma) boundaries at 725 and $~ 827 \mathrm{~m} \mathrm{CSF}$ A, respectively, as well as the Subchron C3n.4n (Thvera) interval (4.997-5.235 Ma), close to the Pliocene/Miocene boundary (Figure F11).

\section{Physical properties}

Physical properties measurements at Site U1461 were performed using the WRMSL, NGR sensor, and discrete sampling. Light-colored sediments were discriminated by high L* values and corresponded to relatively low MS and high grain density. This pat- tern was interpreted to result from high micrite and low detrital clay components in these sediments. Thermal conductivity of sediments increases gradually with depth, from about $1 \mathrm{~W} /(\mathrm{m} \cdot \mathrm{K})$ in the upper portion of Holes U1461A and U1461B to $\sim 1.8 \mathrm{~W} /(\mathrm{m} \cdot \mathrm{K})$ at $\sim 1000 \mathrm{~m}$ CSF-A in Hole U1461D. These measurements were used in combination with downhole in situ temperature measurements to calculate a geothermal heat flux of $41.1 \mathrm{~mW} / \mathrm{m}^{2}$. Between 125 and $450 \mathrm{~m}$ CSF-A, sonic velocity measurements by both the WRMSL and discrete sampling were often unsuccessful, as the cored material is characterized by a large degree of expansion, hampering such measurements. However, in the deeper parts of Holes U1461B and U1461D, discrete measurements of sonic velocity were successful; velocities gradually increase with depth from $\sim 1750 \mathrm{~m} / \mathrm{s}$ at $450 \mathrm{~m}$ CSF-A to $\sim 2800 \mathrm{~m} / \mathrm{s}$ at $925 \mathrm{~m}$ CSF-A. In the lower part of Hole U1461D (925-1080 m CSF-A), sonic velocities are relatively constant and range between 2400 and $2900 \mathrm{~m} / \mathrm{s}$. Porosity is about $60 \%-$ $70 \%$ in the top $50 \mathrm{~m}$ and decreases to $28 \%-34 \%$ at the bottom of the deepest hole (Hole U1461D). Grain density averages $\sim 2.75 \mathrm{~g} / \mathrm{cm}^{3}$, with high values reflecting the presence of aragonite, which occurs in varying amounts in the top half of the cored interval (upper $\sim 600 \mathrm{~m})$.

\section{Downhole logging}

Downhole measurements in Hole U1461D consisted of runs with the triple combo and the FMS-sonic tool strings. Unfortunately, the MS and FMS data obtained during wireline logging were judged not to be of sufficient quality for interpretation. The wireline NGR data agree well with data obtained from whole-round cores (Figure F11). In the upper $450 \mathrm{~m}$, NGR is relatively low, except for some distinct peaks. The NGR data show that the large peaks in the upper $460 \mathrm{~m}$ were mainly driven by variations in $\mathrm{U}$ content. At 450 $\mathrm{m}$ WMSF, there is a stepwise increase in NGR values to 35 counts/s; in the interval between 450 and $820 \mathrm{~m}$ WMSF NGR fluctuates around 35 counts/s, increases further to 40 counts/s between 820 and $850 \mathrm{~m}$ WMSF, and then is stable between 850 and $1000 \mathrm{~m}$ WMSF. Many NGR peaks and troughs observed in cores were also found in the downhole logs and were used for core-log correlation. This correlation indicates that the offset between wireline (WMSF) and coring (CSF-A) depths varies between 4 and $8 \mathrm{~m}$ throughout Hole U1461D. In the upper $450 \mathrm{~m}$, density and porosity measurements are unreliable because of partial collapse of the hole, but deeper than $450 \mathrm{~m}$ WMSF, there is good agreement between the wireline and core-based values. Porosity decreases from $\sim 48 \%$ at $450 \mathrm{~m}$ WMSF to $\sim 30 \%$ at $1030 \mathrm{~m}$ WMSF, whereas bulk density increases from 2.0 to $2.2 \mathrm{~g} / \mathrm{cm}^{3}$ in the same depth interval. Overall, where the logging underestimated bulk density, it overestimated porosity compared to data obtained from discrete samples.

\section{Stratigraphic correlation}

The upper $285 \mathrm{~m}$ of Site U1461 was triple cored using a combination of the piston coring (advanced piston corer [APC] and HLAPC) and XCB systems. This interval was correlated and a splice was generated, although there is less confidence in the correlation in some intervals between 240 and $285 \mathrm{~m} \mathrm{CSF-A.} \mathrm{This} \mathrm{lower} \mathrm{confi-}$ dence is related to the low variation in NGR and MS data (e.g., Cores 356-U1461A-30F and 31F, 356-U1461B-27F through 29F, and 356-U1461C-26F through 28F) coupled with the recovery of $4.7 \mathrm{~m}$ cores (HLAPC) instead of full length $(9.5 \mathrm{~m})$ APC cores. Although the HLAPC enabled greater recovery of high-quality core overall, the relative size of the gaps between cores is greater than with the $\mathrm{APC}$ and a high affine growth factor (a measure of the fractional 
stretching of the composite section relative to the drilled interval [ 114\%]) also made correlation more challenging. The deeper section penetrated in Holes U1461B (Cores 81X through 126X) and U1461D (Cores 5R through 61R) was also correlated, but significant recovery gaps do not permit the generation of a continuous section.

Sedimentation rates (Figure F11) are generally low in the Miocene and remain low across the unconformity and into the early Pliocene. Sedimentation rates more than double in middle Pliocene Zone NN15 and decrease to around $8 \mathrm{~cm} / \mathrm{ky}$ around the Pliocene/Pleistocene boundary. Rates increase again in the early Pleistocene, but the very high rates $(37-52 \mathrm{~cm} / \mathrm{ky})$ are associated with gravity flows. Rates decrease in the latest Pleistocene $(0.44 \mathrm{Ma})$ to $6-13 \mathrm{~cm} / \mathrm{ky}$ but are still well above average sedimentation rates in the deep sea.

\section{Site U1462}

Site U1462 is $50 \mathrm{~km}$ north of the Montobello Islands in the NCB adjacent $(\sim 150 \mathrm{~m})$ to the Fisher-1 Well. Site U1462 is on the outer edge (87 m water depth) of a middle ramp (James et al., 2004). The seabed in the region is carbonate-rich ( $>90 \mathrm{wt} \%)$ gravel and sand with minor mud (Jones, 1973; James et al., 2004). Coring at Site U1462 targeted a sequence of shelfal to shelf-edge carbonates that overlie a Miocene sand unit (the Bare Formation).

The primary aim of coring Site U1462 was to obtain a record of the variation in ITF connectivity over the last $5 \mathrm{My}$. Previous analyses of foraminifers in 28 sidewall cores from the adjacent Fisher-1 Well revealed carbonates that contain horizons of biogeographically significant Indo-Pacific foraminifers (sensu Gallagher et al., 2009), suggesting intermittent ITF connectivity. Further analyses are likely to reveal a more complete record of ITF connectivity than previously recognized. Another objective of Site U1462 was to date strata adjacent to several drowned reefs (Gallagher et al., 2014b) to determine the age and environmental conditions of their onset. Facies and fossil paleoenvironmental analyses of the succession will shed light on when, how, and why these reefs first developed and why they drowned. An additional aim was to obtain an interglacial Pliocene-Pleistocene record of the Australian monsoon. Site U1462 was closer to the shoreline during this time than Site U1461 and is likely to yield significantly more terrigenous material. Finally, postexpedition analyses of a variety of shallow- and deep-water carbonate facies will allow detailed estimates of Pliocene-Pleistocene paleobathymetry and subsidence.

\section{Lithostratigraphy}

The lithostratigraphy of Site U1462 is divided into four units (Figure F12):

- Unit I (Hole U1462A = 0-300.90 m CSF-A, Hole U1462B = 0$47.80 \mathrm{~m}$ CSF-A, and Hole U1462C $=33.00-256.70 \mathrm{~m}$ CSF-A) is characterized by partially to fully lithified, light grayish green to dark greenish gray nonskeletal packstone with lesser amounts of skeletal packstone to grainstone. The grainstone consists mainly of medium to coarse sand-sized grains with minor amounts of gravel and fine sand, as well as macrofossils, peloids, and ooids. Common macrofossils include bivalves, gastropods, barnacles, solitary corals, echinoderms, scaphopods, bryozoans, brachiopods, and serpulids. Small and larger benthic foraminifers are common, whereas planktonic foraminifers are scarce. Some sedimentary structures, such as planar laminations, slight to moderate bioturbation, and sharp to wavy, gradational, and bioturbated contacts are visible in the few cores with greater recovery.
The transition from Unit I to II is characterized by the disappearance of large $(>250 \mu \mathrm{m})$ peloids, a distinct increase in planktonic foraminifers and siliciclastic components, and a transition from neritic to hemipelagic facies.

- Unit II (Hole U1462A = 300.90-777.30 m CSF-A and Hole $\mathrm{U} 1462 \mathrm{C}=256.70-777.88 \mathrm{~m}$ CSF-A) mainly consists of lithified olive-gray packstones with some wackestone intervals. Grain size is gradational, from very fine sand-sized grains to coarse sand-sized grains toward the base of Unit II. Diverse and abundant macrofossils in the upper part of Unit II include bivalves, gastropods, scaphopods, bryozoans, and echinoderms, but bioclasts (mainly bivalve fragments) become much less common with depth. In contrast, small benthic foraminifers are common throughout Unit II. Bioturbation is variable throughout the unit, and there is evidence for gravitational flows and other smallscale mass transport deposits (e.g., laminations, grading, and contact surfaces) toward the base of Unit II.

- Unit III (Hole U1462A = 777.30-843.03 m CSF-A and Hole $\mathrm{U} 1462 \mathrm{C}=777.88-843.48 \mathrm{~m}$ CSF-A) is distinguished from Unit II by higher quartz content. In Hole U1462A, Unit III consists of lithified gray to olive-gray packstone with fine to medium sandsized quartz grains and various macrofossils, including bivalves, gastropods, bryozoans, echinoderms, and small benthic foraminifers. In Hole U1462C, the transition between Units II and III is characterized by a change in the lithology from packstone to grainstone and a marked contact (a pyrite-rich cemented interval). Below the grainstone interval, Unit III mainly consists of packstone with primarily coarse to medium sand-sized grains; disseminated pyrite is also common. At the base of the unit, the lithology transitions to dark greenish gray, coarse-grained, poorly sorted sandstone containing common LBFs. Bioturbation is more intense in Hole U1462C than Hole U1462A, whereas sedimentary features (e.g., parallel laminations, grading, and bioturbated contacts) are similar throughout the unit in both holes.

- Unit IV (Hole U1462A = 843.03-849.67 m CSF-A and Hole $\mathrm{U} 1462 \mathrm{C}=843.48-946.09 \mathrm{~m}$ CSF-A) primarily consists of dolostone and quartz-rich sandstone with common anhydrite nodules, intervals of anhydrite rock, and associated chickenwire structures. The top of Unit IV is defined by the first appearance of macroscopic anhydrite nodules and an increase in dolomite. Unit IV varies in color from light brown to gray to white (anhydrite nodules and anhydrite rock) with generally coarse to medium sand-sized grains and minor intervals of fine sand. Bioturbation is slight to moderate but sporadic throughout the unit. Burrows are often filled with dolomite. Macrofossil fragments occur in low numbers throughout the unit and include solitary corals, bivalves, echinoderms, small benthic foraminifers, and fossil molds (e.g., gastropods and bivalves). Parallel laminations are more frequent in the upper part of the unit, whereas dissolution cavities and intermittent moldic porosity appear in the lower part. Contact surfaces are uncommon but if present typically form sharp subhorizontal surfaces. Pyrite grains are intermittently common and sometimes coat intraclasts, quartz, and anhydrite grains.

\section{Biostratigraphy and micropaleontology}

Core catcher samples from Site U1462 were processed at $20 \mathrm{~m}$ resolution. Nannofossil analyses were done at $10 \mathrm{~m}$ resolution in selected intervals to better constrain biostratigraphic datums between 
Figure F12. Site U1462 summary showing core recovery (11 = drilled interval in Hole U1462C), lithostratigraphic units, age, magnetostratigraphy, biostratigraphy, NGR, and wireline HSGR. Gray bars = casing depth; note the resulting dampened signal of the gamma log. Biostratigraphic zone boundary ages are shown. Age-depth model was produced from select biostratigraphic datums (see Table T7 in the Site U1462 chapter [Gallagher et al., 2017f]) (solid circles = calcareous nannofossil, open circles = planktonic foraminifer). Sedimentation rates are calculated separately for planktonic foraminiferal (blue dashed line) and calcareous nannofossil (green line) datums and assume a linear sedimentation rate between datums. Benthic foraminiferal assemblages were smoothed to generate this synthesis, resulting in slight differences from data presented in hole summaries.

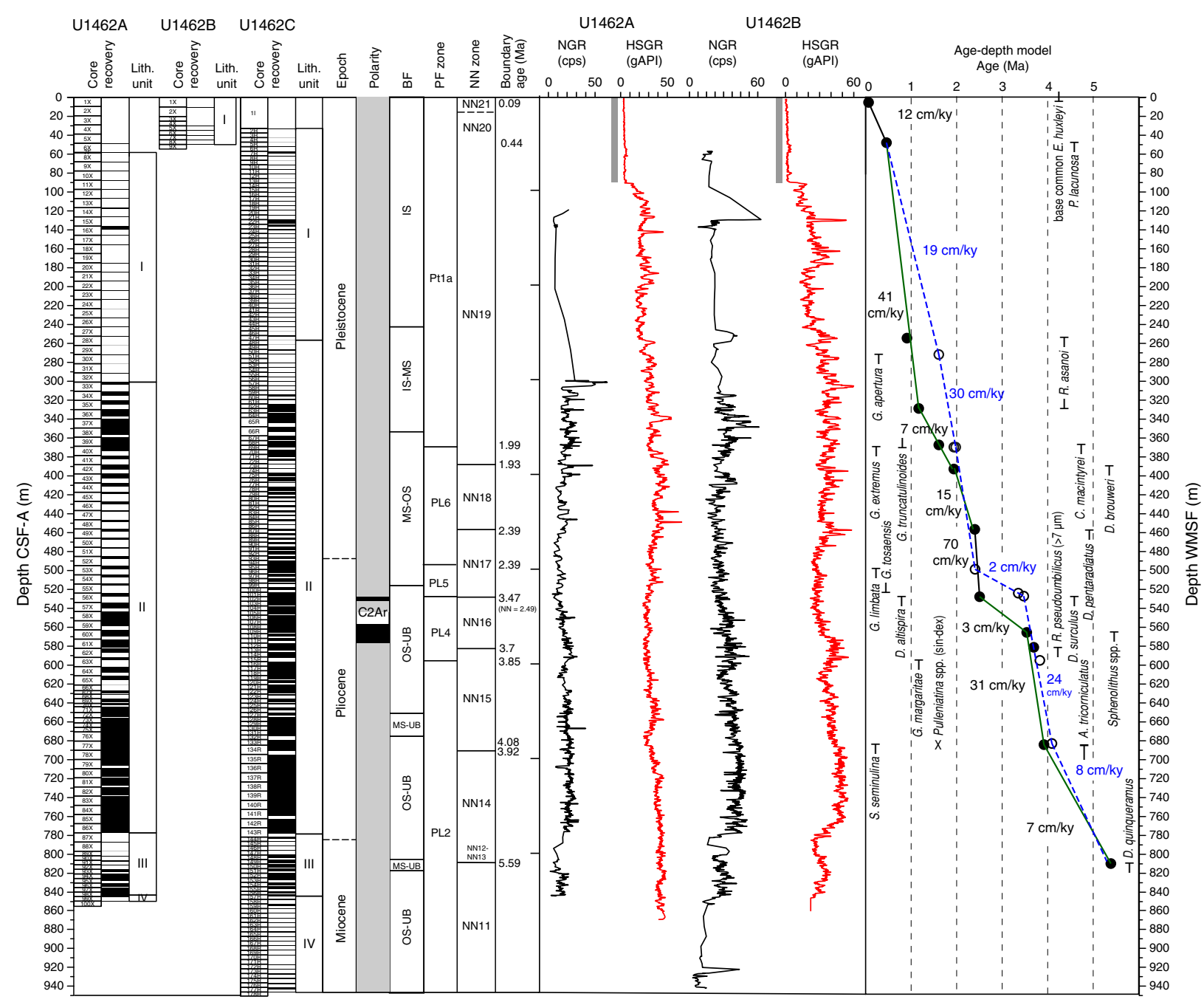

Holes U1462A-U1462C, and extra benthic foraminiferal samples were taken from selected intervals to better constrain assemblage changes between core catcher samples (Figure F12). The upper 390 $\mathrm{m}$ of Site U1462 contain Pleistocene sediments $(<1.93 \mathrm{Ma}$; Zones NN19-NN21; Biozones Pt1a-Pt1b) that yielded very rare nannofossils and planktonic foraminifers. The top occurrence of $P$. lacunosa at $42.67 \mathrm{~m}$ CSF-A (0.44 Ma) and the top occurrence of Reticulofenestra asanoi at $252.5 \mathrm{~m}$ CSF-A (0.91 Ma) are at similar depths as at Site U1461, whereas older nannofossil (>1.6 Ma) and planktonic foraminifer datums ( $>1.64 \mathrm{Ma}$ ) are offset between these sites. The Pliocene/Pleistocene boundary is between 527.5 and $539.97 \mathrm{~m}$ CSF-A, based on the (rare) presence of D. surculus (2.49 $\mathrm{Ma}$, top of Zone NN16) and the planktonic foraminifer Globorotalia limbata (2.39 Ma, top of Zone PL5). The microfossil and planktonic foraminiferal abundance and preservation improve in the early Pleistocene-Pliocene and the earliest Pliocene-late Miocene intervals between $325 \mathrm{~m}$ CSF-A (Samples 356-U1462A-35X$\mathrm{CC}$ and 356-U1462C-62R-CC) and $827 \mathrm{~m}$ CSF-A (Samples 356U1462A-95X-CC and 356-U1462C-153R-CC). Despite the im- provement in planktonic foraminifer preservation and abundance at 368 m CSF-A, both are still relatively poor compared to Sites U1460 and U1461. The highest diversity is in samples deeper than $420 \mathrm{~m}$ CSF-A (Sample 356-U1462A-87X-CC), which contain up to $90 \%$ planktonic foraminiferal taxa. As the general preservation is poor, some of the biozone markers found at previous sites, such as G. limbata, Pulleniatina primalis, and Sphaeroidinellopsis seminulina, are rare and often deeper than their expected stratigraphic position. Deeper than $\sim 820 \mathrm{~m}$ CSF-A, planktonic foraminiferal abundance markedly decreases and samples are mostly barren. The bases of Holes U1462A (849.67 m CSF-A) and U1462C (946.09 m CSF-A) are barren of microfossils, but Samples 356-U1462A-91X-CC through 95X-CC (807.55-827.46 m CSF-A) and 356-U1462C-149R$\mathrm{CC}$ through 153R-CC (809.15-827.65 m CSF-A) yield a late Miocene age based on the presence of the nannofossils $D$. quinqueramus (defining the Zone NN11/NN12 boundary at $5.59 \mathrm{Ma}$ ) and Reticulofenestra rotaria (short range within Zone NN11B).

Samples from Holes U1462A-U1462C contain between 9\% and $100 \%$ benthic foraminifers with Cibicides spp. and Cibicidoides spp. 
as the most common taxa. Seven assemblages were identified based on benthic abundances:

- Assemblage 1: Operculina spp. and Discorbinella spp.

- Assemblage 2: Amphistegina spp. and Elphidium spp.

- Assemblage 3: Melonis spp., Discorbinella spp., and Nonionoides spp.

- Assemblages 4, 6, and 7: Lenticulina spp., brizalinids, and bolivinids

- Assemblage 5: Pseudorotalia spp., S. raphana, and N. margaritifer

- Assemblage 6: Uvigerina spp.

One to 36 species are present in the samples, and the assemblages show a deepening paleodepth downhole from an inner shelf setting (Assemblages 1-3) to a middle to outer shelf setting (Assemblages 3-5) and finally an outer shelf to upper bathyal/deeper setting (Assemblages 6 and 7). This overall deepening trend is interspersed with horizons of transported shallow taxa (Assemblage 7). Preservation varies from very good to poor throughout the site and was affected by fragmentation, abrasion, and encrustation.

\section{Geochemistry}

Site U1462 is characterized by low headspace gas concentrations. Relatively high calcium carbonate concentrations (up to 89.4 wt\%) are noted shallower than $845 \mathrm{~m}$ CSF-A. At approximately 850 $\mathrm{m}$ CSF-A, a major drop in calcium carbonate content to $3.3 \mathrm{wt} \%$ occurs, denoting the transition into the quartz-rich siliciclastics of the Bare Formation (Wallace et al., 2003). Low TOC (mean value $=0.7$ $\mathrm{wt} \%$ ) and TN (mean value $=0.017 \mathrm{wt} \%$ ) characterize the upper 845 $\mathrm{m}$. As at previous Expedition 356 Sites U1459-U1461, high salinity characterizes IW with a mean value of 123 and a maximum of 153 . Elevated salinity at Site U1462, as well as a number of elemental trends noted in the IW samples, appears to be related to the presence and dissolution of anhydrite. A zone of sulfate reduction is interpreted between $\sim 300$ and $500 \mathrm{~m}$ CSF-A.

\section{Paleomagnetism}

Paleomagnetism investigations focused on NRM and AF demagnetization measurements. As core recovery and quality in Holes U1462A and U1462C were poor, only archive-half sections deeper than 300 m CSF-A from Hole U1462C were measured using the SRM. However, stepwise AF demagnetization was conducted for 24 discrete samples from Hole U1462A. Additionally, IRM acquisition and backfield IRM measurements were performed on four discrete samples from Hole U1462A (Samples 43X-1, 49-51 cm, $54 \mathrm{X}-1,38-40 \mathrm{~cm}, 85 \mathrm{X}-2,51-53 \mathrm{~cm}$, and $93 \mathrm{X}-1,38-40 \mathrm{~cm})$. The samples chosen are representative of sediments that yield high and low MS values from the upper and lower parts of the hole. The samples that have low susceptibility (Samples 43X-1, 49-51 cm, and 93X-1, 38-40 cm) exhibit SIRM patterns that indicate the presence of magnetite and/or titanomagnetite. The other two samples (54X$1,38-40 \mathrm{~cm}$, and $85 \mathrm{X}-2,51-53 \mathrm{~cm})$ show higher SIRM values $(\sim 700$ $\mathrm{mT}$ ) and bimodal behavior, indicating higher coercivity and possibly the presence of pyrrhotite. Remanent coercivity values of the four samples range between 46 and $58 \mathrm{mT}$. Sample 85X-2, 51-53 cm, was AF demagnetized after acquiring IRM, yielding a median destructive field of $40 \mathrm{mT}$. Bulk susceptibility measurements were also performed on all 24 discrete samples, and results ranged from $-6.88 \times$ $10^{-6}$ to $48.05 \times 10^{-6} \mathrm{SI}$. AF cleaning procedures were followed by principal component analysis (PCA) for discrete samples from Hole U1462A, which indicated two different patterns: (1) low coercivity from the top of the hole to $\sim 504 \mathrm{~m}$ CSF-A and (2) higher coercivity from $\sim 580 \mathrm{~m}$ CSF-A to the lowermost measured sample at $836.8 \mathrm{~m}$ CSF-A. This suggests that AF demagnetization on the SRM up to 20 $\mathrm{mT}$ for archive-half sections (Hole U1462C) may not be sufficient to fully reveal the characteristic remanent magnetization (ChRM) deeper than $~ 580 \mathrm{~m}$ CSF-A. Examination of high-coercivity Component 2 data from the PCA of discrete samples from $~ 580 \mathrm{~m}$ CSFA to the bottom of Hole U1462A reveals steeper inclination values than those observed for Component 1 . These steeper inclination values may not originate from a drilling overprint and may correlate with the early part of the Matuyama Chron (C1r), although the wide spacing between discrete samples means that the interpretation of chron boundaries remains inconclusive. Magnetostratigraphic data for Hole U1462C clearly indicate a prominent bias of inclination data toward positive values between Cores 356-U1462C-104R and 114R ( 537.6-586.0 m CSF-A) that, based on the biostratigraphic datums of 3.54 Ma (565.6 m CSF-A) and 3.70 Ma (584.7 m CSF-A), may be related to the upper part (Subchron C2Ar) of the Gilbert Chron.

\section{Physical properties}

Physical properties measurements at Site U1462 were carried out using the WRMSL, NGR sensor, and discrete sampling. Because of poor recovery, WRMSL and NGR data are scarce shallower than $300 \mathrm{~m}$ CSF-A. However, deeper than $300 \mathrm{~m}$ CSF-A, 60\%-70\% core recovery resulted in good coverage by these instruments. Between 300 and $840 \mathrm{~m}$ CSF-A, MS and NGR tend to be in phase and show 20-30 m scale variations, suggesting that they both reflect variations in clay input. Discrete $P$-wave measurements were taken in three different ways: on section halves within the liner, on individual rock pieces, and on cut cubes that were subsequently analyzed for MAD. From the seafloor to $300 \mathrm{~m}$ CSF-A and from 850 to $950 \mathrm{~m}$ CSF-A, which correspond to low recovery intervals where measurements were made on lithified fragments, $P$-wave velocities are scattered and range up to $\sim 5500 \mathrm{~m} / \mathrm{s}$. The $P$-wave velocities of many MAD cube samples show that these rocks tend to have a high degree of anisotropy. $P$-wave velocities correlate well with porosity and follow a power relation with bulk density. Grain densities obtained from MAD measurements correlate with grain densities estimated by XRD. Porosities in the packstones of lithostratigraphic Unit II decrease from $~ 43 \%$ at $300 \mathrm{~m}$ CSF-A to $27 \%$ at $840 \mathrm{~m}$ CSF-A; the rocks above this unit have variable porosities and those deeper have variable but lower porosities. Thermal conductivity measured in Hole U1462A increases with depth from about 1.3 to 2.4 $\mathrm{W} /(\mathrm{m} \cdot \mathrm{K})$ at the bottom of the hole ( 850 m CSF-A).

\section{Downhole logging}

Downhole measurements in Holes U1462A and U1462C consisted of runs with the triple combo, FMS-sonic, and Versatile Seismic Imager (VSI) (Hole U1462C only) tool strings. Unfortunately, the MS data obtained during wireline logging were judged to be of insufficient quality for interpretation. The NGR logs for both holes are in agreement (Figure F12). In the upper $300 \mathrm{~m}$, the wireline NGR log is the only available source of information on this sediment property, as core recovery was low (average $=4 \%$ ). Deeper than 300 $m$ WMSF, the NGR log shows good agreement with NGR data obtained on whole-round cores, with values ranging between 15 and 60 counts/s (Figure F12). Many NGR peaks and troughs observed in cores were also observed in the downhole log and were used for core-log correlation. This correlation indicates that the offset between wireline (WMSF) and coring (CSF-A) depth varies between 1 
and $4 \mathrm{~m}$. Wireline density and porosity measurements are generally in good agreement with those measured on cores except for some intervals with irregularities in the borehole diameter ( $>16.7$ inches). Porosity decreases from $\sim 50 \%$ at $250 \mathrm{~m}$ WMSF to $\sim 30 \%$ at $770 \mathrm{~m}$ WMSF, whereas bulk density increases from 2.0 to $2.25 \mathrm{~g} / \mathrm{cm}^{3}$ in the same interval. Where the log underestimates bulk density, it overestimates porosity in comparison to data obtained from discrete samples. FMS image quality is generally poor. However, around $625 \mathrm{~m}$ WMSF, there are horizontal lineations that were coherent between the four sensing pads, and the character between the two logged holes is similar. The spacing between these alterations ranges from several tens of centimeters to several meters, with thin (several tens of centimeters) resistive layers interbedded within broader more conductive areas (1-2 m). Seismic properties were measured both with the FMS-sonic tool string and the vertical seismic profile (VSP) obtained with the VSI. These two methods yielded sonic velocities that are in agreement with one another, suggesting that the VSP experiment validated the absolute values of the velocities obtained with the FMS-sonic.

\section{Stratigraphic correlation}

A lithology resistant to piston coring in the upper $\sim 300 \mathrm{~m}$ at Site U1462 required the use of the XCB (Hole U1462A) and RCB (Hole $\mathrm{U} 1462 \mathrm{C}$ ) systems at the seafloor. Intervals of high recovery varied with the coring system used, but, in general, recovery was poorest in the upper $300 \mathrm{~m}$. Recovery in Hole U1462A was relatively high from $\sim 545$ to $585 \mathrm{~m} \mathrm{CSF}$-A (Cores 58X through 62X), $\sim 635$ to $735 \mathrm{~m}$ CSF-A (Cores 69X through $86 \mathrm{X}$ ), and $\sim 820$ to $845 \mathrm{~m} \mathrm{CSF-A} \mathrm{(Cores}$ $94 \mathrm{X}$ through $98 \mathrm{X}$ ), whereas the highest recovery intervals in Hole U1462C were $\sim 320-370 \mathrm{~m}$ CSF-A (Cores $62 \mathrm{R}$ through 71R), $460-$ $775 \mathrm{~m}$ CSF-A (Cores 91R through 143R), and 815-825 m CSF-A (Cores 151R through 153R). Unfortunately, within these higher recovery intervals, the cores do not overlap for more than a few meters at a time, so a detailed correlation could not be constructed. However, the wireline gamma ray logs, which correlate well to corebased NGR data, provide an excellent framework for developing windows for high-resolution analyses in higher recovery intervals. For example, Cores 356-U1462A-36X through 40X overlap with Cores 356-U1462C-62R through 65R and 67R through 71R ( 325380 m CSF-A), Cores 356-U1462A-57X through 61X overlap with Cores 356-U1462C-101R through 109R ( 525-565 m CSF-A), and Cores 356-U1462A-94X through 98X overlap with Cores 356U1462C-148R through 157R ( 800-840 m CSF-A).

Sedimentation rates are moderate $(7-8 \mathrm{~cm} / \mathrm{ky})$ in the Miocene and increase to $24-31 \mathrm{~cm} / \mathrm{ky}$ in the early Pliocene (Figure F12). An interval of reduced sedimentation rates is associated with the Pliocene/Pleistocene boundary (the depth varies depending on the datums utilized). Very high $(70 \mathrm{~cm} / \mathrm{ky})$ sedimentation rates occur in the early Pleistocene through at least Zone NN18 (1.93 Ma), based on calcareous nannofossil datums. Sedimentation rates are elevated until the Late Pleistocene, when rates fall. However, the stratigraphic position of the Late Pleistocene datums is uncertain because of the limited recovery in this interval.

\section{Site U1463}

Site U1463 is $\sim 150 \mathrm{~m}$ from the Picard-1 Well (141 m water depth) on a flat outer ramp region (James et al., 2004) and $100 \mathrm{~km}$ southwest of Site U1464. The seabed in the region is poorly sorted carbonate-rich (>90\%) sediment made up of bioclastic gravel, sand, and mud (Jones, 1973; James et al., 2004). The wireline gamma ray log data from the Picard-1 Well reveals high variability and an upward reduction interpreted to be related to subsidence, glacio- eustatic sea level fluctuations, and climate variability from the Pliocene to recent.

The primary aim of coring Site U1463 was to obtain a PliocenePleistocene tropical-subtropical carbonate record to allow us to determine the subsidence extent and rates and interglacial Australian monsoon and tropical shelf-edge oceanographic histories of the region. An additional objective was to date a distinctive irregular seismic reflector postulated to be of Miocene age. Improving the age constraints on this feature will enhance regional seismic interpretations.

\section{Lithostratigraphy}

The lithostratigraphy of Site U1463 is divided into four units (Figure F13):

- Unit I (Hole U1463A = 9.07-13.98 m CSF-A, Hole U1463B = 011.71 m CSF-A, Hole U1463C = 0-14.31 m CSF-A, and Hole $\mathrm{U} 1463 \mathrm{D}=0-15.40 \mathrm{~m}$ CSF-A) lithology is primarily unlithified creamy gray to light greenish gray wackestone and mudstone with abundant peloids. Macrofossils are abundant and diverse and include bivalves, gastropods, bryozoans, serpulids, echinoderms, pteropods, scaphopods, and small benthic foraminifers. Bioturbation is moderate but only occurs intermittently, and there are a few contact surfaces (e.g., gradational, bioturbated, and erosive). The bottom boundary of Unit I is defined by the disappearance of peloids in the sediment.

- Unit II (Hole U1463A = 13.98-18.29 m CSF-A, Hole U1463B = 11.71-112.40 m CSF-A, Hole U1463C = 14.31-112.11 m CSF-A, and Hole U1463D = 15.40-114.30 m CSF-A) consists of wackestone, packstone, and mudstone intervals. Lithologic changes are also expressed as subtle color variations ranging from light greenish gray to creamy gray. Isolated macrofossils occur in darker coarse-grained wackestone and packstone intervals and include a diverse range of mollusks (gastropods, bivalves, and scaphopods), echinoderms, serpulids, and bryozoans. Bioturbation is slight in this unit, and few sedimentary and diagenetic features (gradational to sharp contacts and rare concretions) were noted. The top of Unit III marks the end of the creamy gray intervals in the alternating lithologies of Unit II.

- Unit III (Hole U1463B = 112.40-399.10 m CSF-A, Hole U1463C $=112.11-392.49 \mathrm{~m}$ CSF-A, and Hole U1463D = 114.30-352.80 $\mathrm{m}$ CSF-A) predominantly consists of well-sorted homogeneous mudstone containing fine sand-sized grains and is divided into two subunits, IIIa (Hole U1463B = 112.40-305.81 m CSF-A and Hole U1463C $=112.11-307.11 \mathrm{~m} \mathrm{CSF}-\mathrm{A}$ ) and IIIb (Hole $\mathrm{U} 1463 \mathrm{~B}=305.81-399.10 \mathrm{~m}$ CSF-A and Hole U1463C $=307.11-$ $392.49 \mathrm{~m}$ CSF-A), based on a sharp increase in quartz content observed in smear slides. Visual core description for this unit indicates subtle changes in both color and bioturbation in an otherwise uniform moderately to heavily bioturbated mudstone with rare wackestone. Sedimentary features include rare wavy, sharp, scoured, and gradational contacts and sporadically preserved parallel lamination. Fossils include common small benthic foraminifers and bivalve fragments, and less common constituents include fragments of gastropods, bryozoans, echinoderm spines, crustaceans, scaphopods, barnacles, and worm tubes. Occasional concretions (celestite) occur lower in Subunit IIIa ( 150-250 m CSF-A), with disseminated pyrite grains and nodules becoming common in Subunit IIIb.

- Units IV and V were only recovered in Hole U1463B. The upper boundary of Unit IV (399.10-428.20 m CSF-A) is defined by the first occurrence of grainstone with abundant macrofossils 
Figure F13. Site U1463 summary showing core recovery, lithostratigraphic units, age, magnetostratigraphy, biostratigraphy, MS, and wireline HSGR. Gray bar = casing depth; note the resulting dampened signal of the gamma log. Biostratigraphic zone boundary ages are shown. Age-depth model was produced from select biostratigraphic datums (see Table T6 in the Site U1463 chapter [Gallagher et al., 2017g]) (solid circles = calcareous nannofossil, open circles = planktonic foraminifer). Sedimentation rates assume a linear sedimentation rate between datums. Benthic foraminiferal assemblages were smoothed to generate this synthesis, resulting in slight differences from data presented in hole summaries.

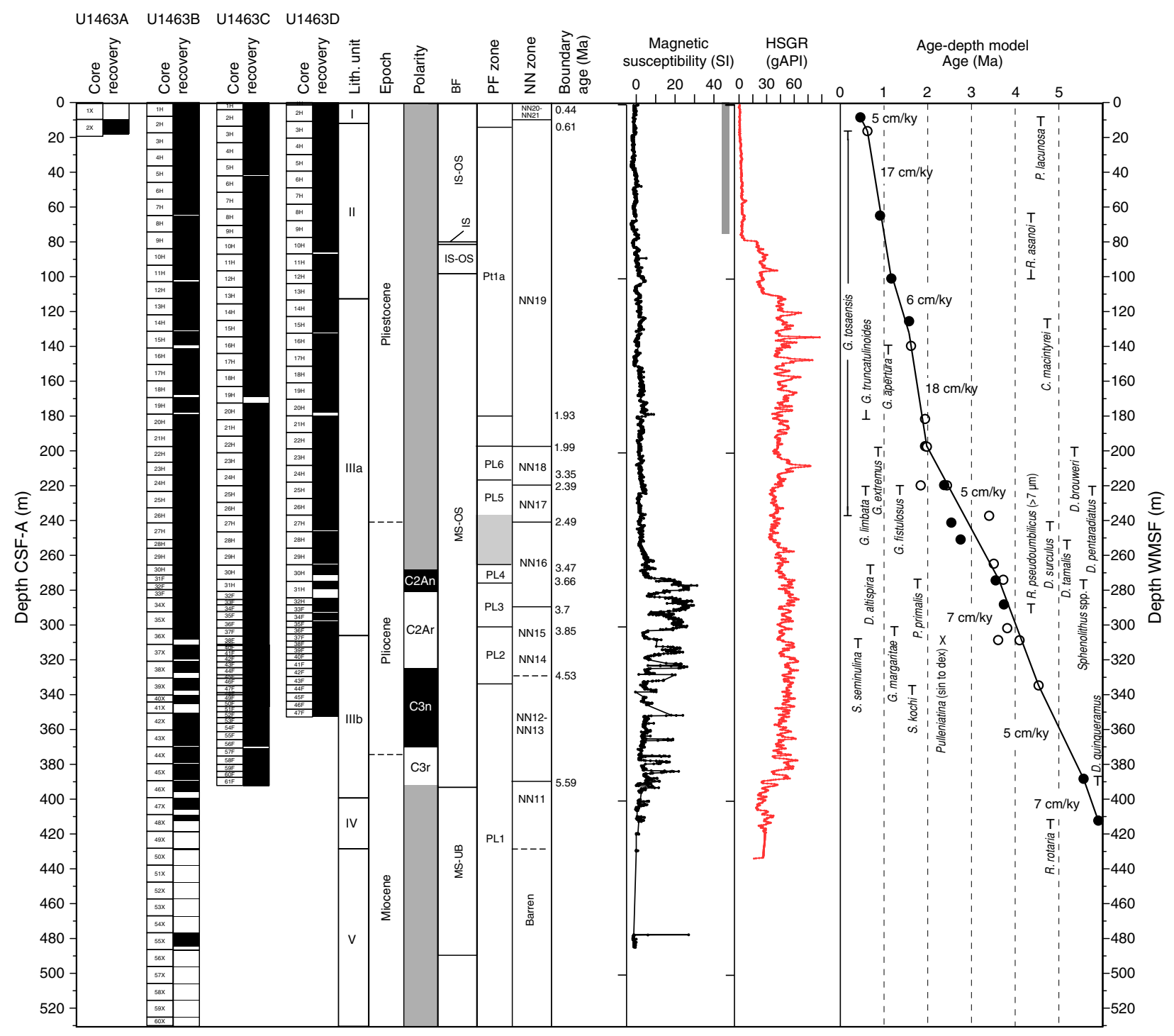

(mainly bivalve fragments). The unit is further characterized by an increased dolomite content as observed in both smear slides and XRD analyses.

- Unit V (428.20-525.25 m CSF-A) is creamy gray to light brown dolostone with sand-sized grains of pyrite and/or glauconite that occur in patches and as scattered grains throughout the matrix. Gypsum/anhydrite nodules, dissolution features, and fine vein structures characterize the dolostone. Both bioturbation and macrofossils are locally common, and bioclasts consist mainly of bivalves and occasional bryozoans and foraminifers.

\section{Biostratigraphy and micropaleontology}

Site U1463 yielded a complete stratigraphic succession from the early Pleistocene to late Miocene, with abundant and well-preserved calcareous nannofossils. The Pliocene/Pleistocene boundary (2.58 Ma; within Zone NN16) is between 240.7 and 265.87 m CSF-
$\mathrm{A}$, and the Miocene/Pliocene boundary (5.33 Ma; within Zone $\mathrm{NN} 12$ ) is between 345 and $379 \mathrm{~m}$ CSF-A. Planktonic foraminiferal abundance and preservation at Site U1463 is the best among all sites investigated so far during Expedition 356. Moderate to very good preservation is typical of the entire Pleistocene to Pliocene with common to abundant planktonic foraminifers between 7.78 and $378.9 \mathrm{~m}$ CSF-A. Biostratigraphic marker species were identified for the Middle Pleistocene (0.61 Ma; top of G. tosaensis) at $46 \mathrm{~m} \mathrm{CSF-A,}$ the Pliocene/Pleistocene boundary below the top of G. limbata (2.39 Ma; 220.54 m CSF-A), D. altispira (3.47 Ma; 265.87 m CSF-A) for the Pliocene, and Sphaeroidinellopsis kochi (top at $4.53 \mathrm{Ma}$; $334.71 \mathrm{~m} \mathrm{CSF}-\mathrm{A}$ ) for the early Pliocene. An extended interval that is barren or contains heavily recrystallized foraminifers and very rare nannofossils occurs deeper than $429.28 \mathrm{~m}$ CSF-A to the bottom of Hole U1463B ( 525 m CSF-A). The lowermost biostratigraphic datum (nannofossils) suggests Sample 356-U1463B-48X-CC (412.44 
$\mathrm{m}$ CSF-A) is older than 5.94 Ma (top of $R$. rotaria, Zone NN11) (Figure F13).

Samples from Holes U1463A-U1463C contain between 10\% and $100 \%$ benthic foraminifers with Cibicidoides spp. as the most common taxa. Five assemblages were identified based on benthic abundances:

- Assemblage 1: Quinqueloculina spp. and Textularia spp.

- Assemblage 2: Operculina spp. and Amphistegina spp.

- Assemblage 3: Cibicidoides spp., Rotalinoides gaimardii, and Lenticulina spp.

- Assemblage 4: Pseudorotalia spp., Neoeponides spp., Planorbulinella larvata, and Bolivina spp.

- Assemblage 5: Cibicidoides spp., Anomalinoides spp., and A. lessonii

One to 43 species are present in the samples, and the assemblages suggest paleodepths that start moderately deep (middle to outer shelf; Assemblage 1) and continue to fluctuate between middle to outer shelf and bathyal settings for the remainder of the site (Assemblage 3) with frequent downslope transported, diverse, shallowwater taxa within deeper foraminiferal assemblages (Assemblages 2, 4 , and 5). Preservation was affected by fragmentation, abrasion, and encrustation and varies from very good to poor throughout the site but is most frequently good to moderate with poor preservation only occurring from deeper than $390 \mathrm{~m} \mathrm{CSF}$-A to the base of the site.

\section{Geochemistry}

At Site U1463, 56 samples were analyzed for headspace gas content, 25 samples (5-15 cm whole rounds) for IW geochemistry, and 25 samples for TOC, $\mathrm{CaCO}_{3}$, and TN. IW samples were not collected in Holes U1463C or U1463D because these two holes recovered a section already sampled in Holes U1463A and U1463B. Only one sample was taken from Hole U1463A. In general, elevated salinity characterizes the site with a value of 35 at the top, increasing gradually with depth to a value of 111 at the bottom ( 525 m CSFA), with a mean value of 70 . Similar to Site U1462, the high salinity and a number of elemental trends in the IW samples appear to be related to the presence and dissolution of anhydrite, which is present at the bottom of the section (lithostratigraphic Unit V; 428.20$525.25 \mathrm{~m}$ CSF-A). A number of elements exhibit increasing concentrations with depth, including sodium, chloride, barium, bromine, calcium, potassium, and sulfate. Site U1463 is characterized by low headspace gas concentrations, with methane concentrations ranging from 1.6 to 13.4 ppmv and almost no detection of higher molecular weight hydrocarbons. Further, this site is characterized by high $\mathrm{CaCO}_{3}$ content $($ mean value $=77.5 \mathrm{wt} \%)$, low $\mathrm{TOC}$ (mean value $=$ $0.7 \mathrm{wt} \%$ ), and low TN (mean value $=0.031 \mathrm{wt} \%$ ).

\section{Paleomagnetism}

Paleomagnetism investigations focused on NRM and AF demagnetization measurements. SRM results are reported from cores recovered with the APC and XCB coring systems from 0 to $390 \mathrm{~m}$ CSF-A from Holes U1463B and U1463C. A total of 11 discrete samples were taken from Holes U1463B and U1463C. IRM acquisition and backfield IRM measurements were performed for three discrete samples from Hole U1463B to determine the demagnetization behavior of sediment at this site. SIRM values exhibit a broad range. Two out of the three discrete samples exhibit SIRM at $~ 100-200$ $\mathrm{mT}$; for one sample it was not possible to reach saturation in an impulse peak field of 1.2 T. Remanent coercivity values of the three samples range between 35 and $75 \mathrm{mT}$. One of the discrete samples was chosen for AF demagnetization after IRM acquisition, yielding a median destructive field between 30 and $40 \mathrm{mT}$. Bulk susceptibility measurements were also performed on all 11 discrete samples

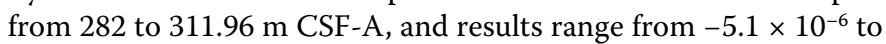
$140.7 \times 10^{-6} \mathrm{SI}$. These values exhibit an increasing trend that is similar to the equivalent measurements on the whole-round and split cores reported by the physical properties team.

Archive-half sections from Holes U1463B and U1463C were measured on the SRM. In the upper two-thirds of Hole U1463B (0$275 \mathrm{~m}$ CSF-A), there is a steep negative inclination pattern when inclination values after AF cleaning up to $20 \mathrm{mT}$ are compared to NRM values. From $\sim 275$ to 290 m CSF-A, inclination values after 20 $\mathrm{mT}$ cleaning gradually become less steep and shift toward NRM values. The lower part of the core, from 290 m CSF-A to the bottom of the succession, is characterized by inclination values that are hardly affected by AF cleaning up to $20 \mathrm{mT}$, indicating the presence of a second, higher coercivity phase in that interval. The transition at $\sim 290 \mathrm{~m} \mathrm{CSF}-\mathrm{A}$ could be related to lithologic changes from partially lithified mudstones to wackestones and the formation of iron sulfide magnetic carriers, such as greigite $\left(\mathrm{Fe}_{3} \mathrm{~S}_{4}\right)$ and pyrrhotite $\left(\mathrm{Fe}_{1-\mathrm{x}} \mathrm{S}\right)$, from alteration of disseminated pyrite. However, the demagnetization behavior of Sample 356-U1463B-37X-1, 86-88 cm (311.96 m CSF-A), clearly indicated that ChRM cannot be achieved using the standard AF demagnetization step sequence (NRM, 10, and $20 \mathrm{mT}$ ) for the deeper sediments ( 270-390 m CSF-A). Therefore, demagnetization steps at NRM, 15, and $30 \mathrm{mT}$ were used in this interval for Hole U1463C and produced a more accurate determination of ChRM, which was used for magnetostratigraphic interpretations. Magnetostratigraphic data for Hole U1463C indicate the Gauss/Gilbert boundary (3.596 Ma) at $\sim 282 \mathrm{~m} \mathrm{CSF-A}$. In addition, it is possible that the transition between Subchron C3n and C3r intervals $(5.235 \mathrm{Ma})$ is at $\sim 375 \mathrm{~m} \mathrm{CSF}$-A, where it corresponds with a biostratigraphic datum of $5.59 \mathrm{Ma}$ at $\sim 392.5 \mathrm{~m}$ CSF-A (Figure F13).

\section{Physical properties}

Physical properties measurements were performed using the WRMSL, NGR sensor, and discrete sampling on cores. NGR measurements revealed similar trends and variations in all holes. MS values revealed 10-20 m scale variability, with maximum amplitude (about 30 SI) from 270 to $330 \mathrm{~m}$ CSF-A. MS patterns are consistent between holes and between the WRMSL and SHMSL. Variability at the $10-20 \mathrm{~m}$ scale is also observed in NGR and $P$-wave velocity measured on the WRMSL, which was verified through discrete measurements. $P$-wave velocity increases from about 1500 to 1900 $\mathrm{m} / \mathrm{s}$ in the top $300 \mathrm{~m}$ of the site. From 300 to $390 \mathrm{~m}$ CSF-A, discrete measurements of $P$-wave velocity show diverging trends between Holes U1463B (cored by the XCB system) and U1463C (cored by the HLAPC system), suggesting that coring methods impact this sediment property. Porosity decreases from $64 \%$ to $40 \%$ at $250 \mathrm{~m}$ CSF-A and is scattered with a range of $13 \%-43 \%$ deeper than $270 \mathrm{~m}$ CSF-A.

\section{Downhole logging}

Downhole measurements were conducted in Hole U1463B. The triple combo tool string was run between $452 \mathrm{~m} \mathrm{WMSF}$ and the seafloor and was used to measure borehole width, NGR, bulk density, porosity, resistivity, and MS. In the upper part of the borehole, NGR increases with depth in a stepwise manner with steps at $\sim 78$ and $\sim 110 \mathrm{~m}$ WMSF, the first of which corresponds to the end of the drill pipe (Figure F13). Between 110 and 200 m WMSF, NGR shows 
strong meter-scale variability and ranges between 30 and 80 counts/s. At $208 \mathrm{~m}$ WMSF, a prominent peak in NGR is observed. Between 210 and $385 \mathrm{~m}$ WMSF, NGR remains relatively high and ranges between 30 and 60 counts/s. The wireline NGR log is in good agreement with core-based NGR and allows for correlation of wireline and core data. MS measurements were affected by changing borehole temperatures and were judged to be of insufficient quality for interpretation. Wireline bulk density and porosity measurements correspond to the results of discrete core sampling in most of the logged interval. $P$-wave sonic velocities measured with the FMS-sonic tool string from 444 to $122 \mathrm{~m}$ WMSF are consistently higher than sonic velocities measured on cored material. However, the same $20-30 \mathrm{~m}$ scale variability in sonic velocity is present in both wireline logs and core-based measurements. Although borehole diameter was relatively large ( 16 inches), FMS images are generally of good quality with both passes yielding consistent images. From $\sim 443 \mathrm{~m}$ WMSF upward, the FMS shows $20-50 \mathrm{~cm}$ wide horizontal resistive bands with diffuse edges about $5 \mathrm{~m}$ apart. Deeper than $406 \mathrm{~m}$ WMSF, there are occasional sharp bands of high conductivity with thicknesses $<5 \mathrm{~cm}$. Uphole from $\sim 380 \mathrm{~m}$ WMSF, these thin conductive bands become more prevalent and some have the appearance of being tilted from the horizontal by $<20^{\circ}$.

\section{Stratigraphic correlation}

Site U1463 was triple cored using the APC, HLAPC, and XCB systems in order to recover a complete and continuous section. The stratigraphic correlators provided coring guidance to ensure recovery gaps between holes did not overlap and to determine the depth at which the mudline core was taken for the second and third APC holes. Correlation was possible for the upper $\sim 350 \mathrm{~m}$ between Holes U1463B, U1463C, and U1463D, and a splice of the upper 300 $\mathrm{m}$ was generated from the correlation. Variability in lithology and coring methods between holes caused some uncertainty in the correlation, which is based on the sediment physical properties data. Uncertainty was also introduced by a downhole switch from an MSbased correlation to a NGR-based correlation.

Sedimentation rates are generally high at this site, well above typical pelagic values. Specifically, sedimentation rates are moderate through the Pliocene and increase $(11-19 \mathrm{~cm} / \mathrm{ky})$ in the Pleistocene (Zone NN18/NN19 boundary to Biozone PT1a/Pt1b boundary) before declining to moderate levels $(5 \mathrm{~cm} / \mathrm{ky})$ in the Middle Pleistocene to recent.

\section{Site U1464}

At $270 \mathrm{~m}$ water depth, Site U1464 is currently in an outer ramp setting (James et al., 2004) approximately $50 \mathrm{~km}$ southeast of the Rowley Shoals. The seabed in the vicinity of the site is poorly sorted, carbonate-rich (>90\%) sediment made up of bioclastic gravel, sand, and mud (Jones, 1973; James et al., 2004). Site U1464 is $5 \mathrm{~km}$ updip from a drowned "fossil" reef/shoal described by Jones (1973) and Ryan et al. (2009) and connected to the site by parallel laterally persistent seismic reflectors. Therefore, improved ages for these reflectors may allow us to date the initiation and demise of this reef/shoal. The proximity of Site U1464 to a previously identified drowned shoal makes this site unique and significant: stratigraphic data and paleobathymetric determinations obtained will allow robust estimates of the subsidence history of this part of the NWS and its role in carbonate platform drowning. As the most northern site of the Expedition 356 coring transect, the sediment and biota at Site U1464 are likely to record strong Western Pacific Warm Pool and
ITF signals vital to understanding the history of these important oceanic features. The strata of this site were also targeted for a Pliocene-Pleistocene record of the Australian monsoon and aridity.

\section{Lithostratigraphy}

The lithostratigraphy of Site U1464 is divided into five units (Figure F14). The unit boundaries were defined using visual core description, smear slide observations, NGR data, XRD, and thin section analyses from Holes U1464B-U1464D:

- Unit I (Hole U1464B = 0-44.10 m CSF-A and Hole U1464D = 0-43.00 m CSF-A) is 43-44 m thick and consists of unlithified creamy gray sediments with coarse silt- to fine sand-sized peloids in varying abundances, with the last occurrence of peloids marking the base of the unit. The sediment is mainly skeletal grainstone in the upper part, mudstone dominating the middle and lower part of the unit, and thin interbedded packstone and wackestone intervals. The generally low siliciclastic content of the unit is dominated by mica with minor amounts of quartz. The unit contains abundant foraminifers and pteropods with some macrofossils (e.g., scaphopods, bivalves, and solitary corals).

- Unit II (Hole U1464B = 44.10-138.20 m CSF-A and Hole $\mathrm{U} 1464 \mathrm{D}=43.00-140.39 \mathrm{~m}$ CSF-A) is $\sim 95 \mathrm{~m}$ thick and consists mainly of unlithified, homogeneous wackestone that includes a packstone interval and a relatively high abundance of authigenic glauconite and glauconitized microfossils. The top of the unit is defined by the loss of peloids as a common sedimentary component. Macrofossils are sparse and concentrated in coarser grained intervals. Bioturbation is slight to moderate throughout the unit. Disseminated pyrite grains are common in the lower part of the unit along with occasional pyrite nodules and celestite concretions. Siliciclastic content generally increases but is variable, particularly in the lower half of the unit.

- Unit III (Hole U1464B = 138.20-308.86 m CSF-A and Hole $\mathrm{U} 1464 \mathrm{D}=140.39-308.74 \mathrm{~m}$ CSF-A) is $\sim 170 \mathrm{~m}$ thick, with the top of the unit marked by a transition from wackestone to mudstone, a decrease in sand-sized siliciclastic content, and an increase in clay-sized sediment. Overall siliciclastic content is very fine grained in Unit III, with a near absence of coarse-grained material. The unit consists mainly of unlithified grayish green to greenish gray homogeneous mudstone with moderate bioturbation and common disseminated pyrite and pyrite concretions. Macroscopic bioclasts are very sparse, but microfossils are abundant and well preserved with a marked increase in calcareous nannofossils noted in smear slides.

- Unit IV (Hole U1464B = 308.86-316.95 m CSF-A, Hole U1464C $=308.00-521.40 \mathrm{~m}$ CSF-A, and Hole U1464D = 308.74-523.97 $\mathrm{m}$ CSF-A) is $\sim 215 \mathrm{~m}$ thick and marked by a transition to dolomitic packstone. The unit consists of three main intervals of dolomitic limestone separated by two intervals of skeletal limestones. Gypsum nodules are common in the dolomitic intervals and commonly co-occur with anhydrite nodules in the lower 46 $\mathrm{m}$ of the unit. Karstic surfaces, cavities, and moldic porosity are also common, especially in the skeletal limestones. Macrofossils are present and diverse in both lithologies, often occurring as molds. Bioclasts include many organisms typical of shallow habitats, including larger benthic foraminifers (e.g., Cycloclypeus), some zooxanthellate corals, and crustose coralline algae. Siliciclastic material is generally absent in Unit IV.

- Unit V (Hole U1464C = 521.40-832.90 m CSF-A) is $311.50 \mathrm{~m}$ thick and consists primarily of dolomitic limestones (mudstone, 
Figure F14. Site U1464 summary showing core recovery, lithostratigraphic units, age, magnetostratigraphy, biostratigraphy, and NGR. Magnetic polarity is shown in black and white (gray = uncertainty in the data) (see Paleomagnetism in the Site U1464 chapter [Gallagher et al., 2017h]). Biostratigraphic zone boundary ages are shown. Age-depth model was produced from biostratigraphic datums only (see Biostratigraphy and micropaleontology in the Site U1464 chapter [Gallagher et al., 2017h]) and assumes a linear sedimentation rate between datums (solid circles $=$ calcareous nannofossil, open circles $=$ planktonic foraminifer). Sedimentation rates are calculated separately for calcareous nannofossils and planktonic foraminifers where the datums diverge. Note the break in scale for the age-depth model. Benthic foraminiferal assemblages were smoothed to generate this synthesis, resulting in slight differences from data presented in hole summaries.

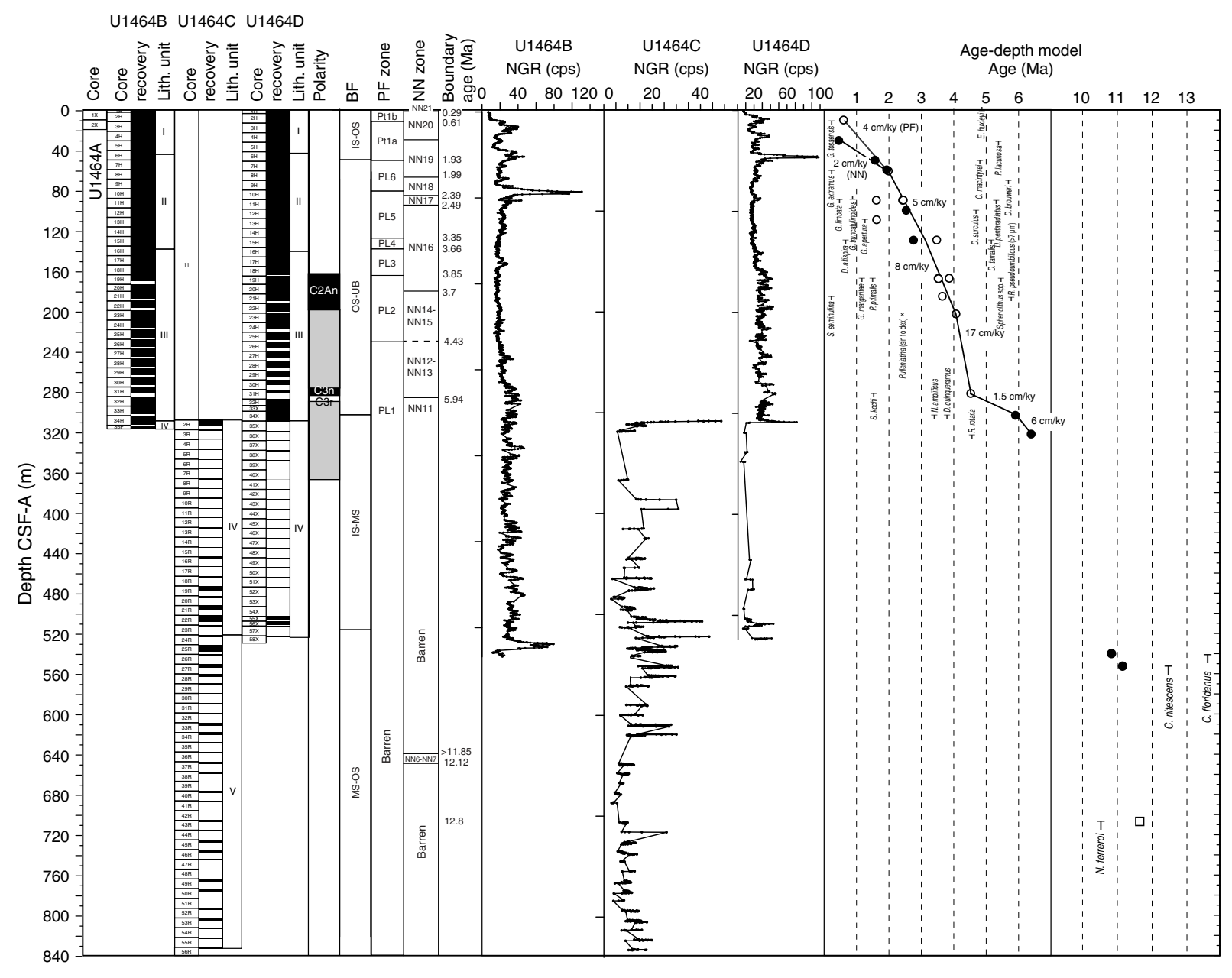

wackestone, packstone, and grainstone) and dolostone. The top of the unit is defined by the first occurrence of littoral deposits. The upper part of the unit $(\sim 100 \mathrm{~m})$ contains several heavily dolomitized intervals, whereas the lower part ( $\sim 55 \mathrm{~m})$ is composed of lithified increasingly coarser packstones and grainstones. Macrofossils include fragments of mollusks, echinoid spines, bryozoans, and LBFs. Macrofossil content generally decreases toward the base of the hole, whereas bryozoans increase in abundance and become common in the lower $10 \mathrm{~m}$. Siliciclastic content continues to be generally absent to low with angular sand-sized quartz noted in the lowermost interval.

\section{Biostratigraphy and micropaleontology}

Site U1464 yielded a complete stratigraphic succession from the early Pleistocene to late Miocene, with usually abundant and wellpreserved calcareous nannofossils. The Pliocene/Pleistocene boundary (2.58 Ma; within Zone NN16) is placed between 97.42 and $108.29 \mathrm{~m} \mathrm{CSF-A}$, and the Miocene/Pliocene boundary (5.33
Ma; within Zone NN12) is placed between 228.4 and 293.15 m CSFA. Planktonic foraminiferal abundance and preservation at Site U1464 is moderate to good for the entire Pliocene-Pleistocene with common to abundant planktonic foraminifers between 2.26 and 293.2 m CSF-A. Biostratigraphic marker species were identified for the Middle Pleistocene (0.61 Ma; top of G. tosaensis) at $11.51 \mathrm{~m}$ CSF-A, the Pliocene/Pleistocene boundary below the top of G. limbata (2.39 Ma; 88.17 m CSF-A), D. altispira (3.47 Ma; $126.3 \mathrm{~m} \mathrm{CSF-}$ A) for the Pliocene, and S. kochi (top at $4.53 \mathrm{Ma} ; 272.57 \mathrm{~m} \mathrm{CSF-A)}$ for the early Pliocene. An extended interval that is barren or contains heavily recrystallized foraminifers and very rare nannofossils occurs deeper than $347.08 \mathrm{~m}$ CSF-A to the bottom of Hole U1464C (832.9 m CSF-A), corresponding to the barren interval from 328.52 $\mathrm{m}$ CSF-A to the bottom of Hole U1464D (523.97 m CSF-A). The lowermost biostratigraphic datum is a benthic foraminifer, which suggests the material in Section 356-U1464C-43R-2 (707.57 m CSFA) is older than $12.8 \mathrm{Ma}$ (top of Nephrolepidina ferreroi TF1-2 [Renema, 2007]) (Figure F14). 
Samples from Site U1464 contain between 6\% and 100\% benthic foraminifers, with Cibicidoides spp. as the most common taxa. Four assemblages can be identified based on benthic abundances:

- Assemblage 1: Textularia spp.

- Assemblage 2: Lenticulina spp., Clavulina subangularis, Neoeponides spp., and Pseudorotalia spp.

- Assemblage 3: Amphistegina spp., Elphidium spp., and Operculina spp.

- Assemblage 4: Cibicidoides spp.

One to 43 species are present in the samples, and the assemblages suggest paleodepths that start relatively deep (inner to outer shelf [Assemblage 1]) at the bottom of the site ( $~ 833 \mathrm{~m} \mathrm{CSF-A)}$ and then deepen (outer shelf to upper bathyal [Assemblage 2]) until around 300-310 m CSF-A. Beginning from this depth, paleodepth rapidly shallows (inner to middle shelf [Assemblage 3]) and then deepens again (inner to outer shelf [Assemblage 4]). Preservation was affected by fragmentation, abrasion, encrustation, and infilling and varied from very good to poor throughout the site but was most frequently good for Assemblages 1 and 2 and poor for Assemblages 3 and 4.

\section{Geochemistry}

At Site U1464, 85 samples were analyzed for headspace gas content, 20 samples (5-15 cm whole rounds) for IW geochemistry, and 23 samples for TOC, $\mathrm{CaCO}_{3}$, and TN. In general, Site U1464 is characterized by the lowest headspace gas concentrations of all of the Expedition 356 sites, with methane ranging from 0 to $3.2 \mathrm{ppmv}$ and almost no detection of higher molecular weight hydrocarbons. Elevated salinity characterizes the site with a value of 35 at the top and increasing gradually with depth to 105 at the bottom, with a mean value of 68. Similar to Sites U1462 and U1463, high salinity at Site U1464 and a number of elemental trends noted in the IW samples appear to be related to the presence and dissolution of anhydrite, which was observed in lithostratigraphic Units IV and V. A number of elements exhibit increasing concentrations with depth, including sodium, chloride, barium, bromine, calcium, potassium, and sulfate. The majority of samples at this site are characterized by high $\mathrm{CaCO}_{3}$ content (mean value $=78.8 \mathrm{wt} \%$ ) and low $\mathrm{TOC}$ (mean value $=0.6$ wt\%) and TN (mean value $=0.018 \mathrm{wt} \%$ ). However, there are two samples from black layers in Sections 356-U1464C-24R-2 and 25R2 that have extremely low $\mathrm{CaCO}_{3}$ content (3.6 and $2.7 \mathrm{wt} \%$ ) but different characteristics in TOC and TN values. The sample at $523 \mathrm{~m}$ CSF-A (Section 24R-2) contains low TOC (0.77 wt\%) and TN (0.034 $\mathrm{wt} \%)$, similar to samples from other depths. In contrast, the slightly deeper sample at $532 \mathrm{~m}$ CSF-A (Section 25R-2) has much higher TOC (1.94 wt\%) and TN (0.079 wt\%), suggesting that, despite appearing visually similar, these black layers represent different depositional environments.

\section{Paleomagnetism}

A total of 20 discrete samples were taken from Holes U1464BU1464D. IRM acquisition and backfield IRM measurements were performed for four selected discrete samples (356-U1464B-18H$4 \mathrm{~W}, 74-76 \mathrm{~cm}, 24 \mathrm{H}-3 \mathrm{~W}, 70-72 \mathrm{~cm}, 356-\mathrm{U} 1464 \mathrm{C}-22 \mathrm{R}-4 \mathrm{~W}, 50-52$ $\mathrm{cm}$, and $34 \mathrm{R}-1 \mathrm{~W}, 46-48 \mathrm{~cm}$ ) chosen according to the observed demagnetization behavior throughout the site. Two samples (356U1464C-22R-4, 50-52 cm, and 34R-1, 46-48 cm) reached SIRM at $\sim 100 \mathrm{mT}$, Sample 356-U1464B-24H-3, 70-72 cm, saturated at 400 $\mathrm{mT}$, whereas Sample $18 \mathrm{H}-4,74-76 \mathrm{~cm}$, did not reach saturation in fields up to $1.2 \mathrm{~T}$. Remanent coercivity values of the four samples range between 44 and $83 \mathrm{mT}$. Bulk susceptibility measurements were also performed on all of the discrete samples, and results range from $-7.95 \times 10^{-6}$ to $110.24 \times 10^{-6} \mathrm{SI}$.

Archive-half sections from Hole U1464D were measured on the SRM to construct the magnetostratigraphy. Resulting intensity values generally range from $10^{-5}$ to $10^{-3} \mathrm{~A} / \mathrm{m}$, with exceptions between $\sim 158$ and $180 \mathrm{~m}$ CSF-A (Cores 356-U1464D-18H through 22H) and between $\sim 245$ and $293 \mathrm{~m}$ CSF-A (Cores $27 \mathrm{H}$ through $32 \mathrm{H}$ ), for which intensity values reach $\sim 10^{-1} \mathrm{~A} / \mathrm{m}$. A persistent negative inclination trend exists from the top of the succession to $\sim 210 \mathrm{~m} \mathrm{CSF-A}$ (Core $23 \mathrm{H})$, from which there is a gradual shift toward lower inclination values and more frequent positive inclination intervals. Magnetostratigraphic data for Hole U1464D indicate the Gauss/Gilbert boundary (3.596 Ma) at $\sim 282 \mathrm{~m}$ CSF-A. In addition, it is possible that the Subchrons C3n/C3r boundary (5.235 Ma) occurs between 272.66 and $277.85 \mathrm{~m}$ CSF-A because it can be constrained by a biostratigraphic datum of $5.59 \mathrm{Ma}$ at $281.39 \mathrm{~m} \mathrm{CSF}$-A (Figure F14).

\section{Physical properties}

Stratigraphic overlap between Holes U1464B-U1464D is confirmed by physical properties patterns, including MS, NGR, and MAD results. Detailed analysis of $P$-wave velocity, as measured in sediments obtained within an interval where three different coring techniques (APC, XCB, and $\mathrm{RCB}$ ) overlap, reveals some significant results related to coring and measurement techniques. $P$-wave velocities measured on XCB and APC cores show parallel trends. However, $\mathrm{XCB} P$-wave velocities fall within two distinct velocity ranges. The lower range is similar to $P$-wave velocities obtained on APC cores and corresponds to the "gravy" portion of the XCB core. A second range is $\sim 150 \mathrm{~m} / \mathrm{s}$ higher and corresponds to the "biscuits." Sediments obtained during RCB coring tend to have 400-650 $\mathrm{m} / \mathrm{s}$ higher velocities than those obtained during APC coring. Evaluation of differences between MAD and GRA bulk densities suggests that the differences are a result of mineralogical variations. This is because MAD measurements incorporate mineralogical differences, whereas GRA bulk density estimates assume constant mineralogy throughout. An estimate of the geothermal heat flux of $59.1 \mathrm{~mW} / \mathrm{m}^{2}$ was derived from a combination of the six in situ temperature estimates and core-based thermal conductivity measurements.

\section{Downhole logging}

Downhole measurements were conducted in Hole U1464C with the triple combo tool string. The deployment of the tool string consisted of a down pass (0-783 m WMSF) and an up pass between 783 and $615 \mathrm{~m}$ WMSF. At $615 \mathrm{~m}$ WMSF on the up pass, the tool became stuck in the hole, probably due to hole cave in, and considerable effort was undertaken to retrieve the tool. We thus canceled planned operations with the FMS-sonic and VSI. Wireline NGR data obtained during the down pass with the triple combo were in agreement with core-based data. Between 84 and 305 m WMSF, wireline NGR ranges between 25 and 55 American Petroleum Institute gamma radiation units (gAPI) and the variability in this interval is the result of variability in $\mathrm{K}$ and $\mathrm{Th}$, whereas the signal from $\mathrm{U}$ is subdued. In the underlying interval, between 305 and 747 m WMSF, NGR ranges between 15 and 40 gAPI and the variability is primarily the result of variations in $U$, rather than variation in $K$ or Th, both of which show generally low concentrations. Downhole MS measurements were affected by temperature and were judged to be of insufficient quality for interpretation. Wireline bulk density and porosity measurements were only carried out in the interval between 764 
and $617 \mathrm{~m}$ WMSF during the up pass. The wireline bulk density measurements in this interval generally agree with core-based MAD results. Wireline porosity measurements, on the other hand, agree with MAD results only in the intervals between 680 and 720 $\mathrm{m}$ WMSF and between 735 and $755 \mathrm{~m}$ WMSF.

\section{Stratigraphic correlation}

Site U1464 was cored to $\sim 840 \mathrm{~m}$ CSF-A using a combination of the APC, XCB, and RCB systems. The upper $200 \mathrm{~m}$ was double cored with the APC system (Holes U1464B and U1464D) and a strong correlation was produced using the NGR data. The correlation was extended to $\sim 320 \mathrm{~m}$ CSF-A with overlap between the APC (Hole U1464B) and XCB systems (Hole U1464D) but is less certain because of recovery gaps and biscuiting in the $\mathrm{XCB}$ cores. A splice could not be created because there were only two holes in the uppermost sections, but most paleoceanographic studies can use the sampling guidance of the correlation, particularly because sedimentation rates are elevated $(17 \mathrm{~cm} / \mathrm{ky})$ in the expanded early Pliocene section that ranges from $\sim 320$ to $180 \mathrm{~m}$ CSF-A in Holes U1464B and U1464D (Figure F14).

Sedimentation rates are not well constrained for the Miocene interval; three datums were determined over $500 \mathrm{~m}$ of low core recovery (Figure F14). However, if deposition was continuous between the LBF datum at $707.57 \mathrm{~m}$ CSF-A and the nannofossil horizon at $552.5 \mathrm{~m}$ CSF-A (see Figure F38 in the Site U1464 chapter [Gallagher et al., 2017h]), then rates were in the range of 25-30 $\mathrm{cm} / \mathrm{ky}$ (the LBF datum represents the youngest possible age, so if the horizon is older, sedimentation rates would be lower). Sedimentation rates increase from $\sim 1.5 \mathrm{~cm} / \mathrm{ky}$ in the lowermost Pliocene to $17 \mathrm{~cm} / \mathrm{ky}$ in upper Zone NN12-NN13 and Zone NN14-NN15, and continue at moderate rates $(5-8 \mathrm{~cm} / \mathrm{ky})$ through the remainder of the Pliocene (Zone NN16) and into the Pleistocene. Upper Pleistocene (Zone NN19-NN21) rates are similarly low (2-4 cm/ky) but differ depending on the biostratigraphic group.

\section{Preliminary scientific assessment}

The shipboard results successfully addressed or exceeded each of the proposed objectives, as discussed below. The high quality of material recovered, despite intermittent core recovery in some sections, and the complete documentation of its geological and geophysical context guarantees an unparalleled series of future studies by the expedition scientific party as well as many other scientists over the coming decades.

\section{Determine the timing and variability of the ITF, Indo-Pacific} Warm Pool, and onset of the Leeuwin Current to understand the controls on Quaternary extratropical carbonate and reef deposition.

At $\sim 29^{\circ} \mathrm{S}$, Sites U1458-U1460 (Figures F1, F15) in the Perth Basin are close to the Houtman-Abrolhos reef system, the most southerly reef complex in the Indian Ocean (Collins et al., 1993). The high-latitude position of these reefs is directly related to the path of the south-flowing warm Leeuwin Current, which is itself controlled by the relative intensity of the Indo-Pacific Warm Pool and ITF variability. Strong seabed cementation prevented Site U1458 from sampling the Quaternary strata of this region, and coring was therefore transferred to the alternate Site U1459. Sites U1459 and U1460 yielded an extended Miocene to Quaternary upper slope to outer shelf carbonate section that will allow, for the first time, investiga- tion of the timing and relative influence of the Leeuwin Current (and the ITF) on the initiation and evolution of reefal development on the Rottnest shelf and Carnarvon ramp system (Collins et al., 2014). Further microfossil and geochemical research on the record at Site U1460 (Figure F16) is likely to show the relative influence of the colder, more nutrient enriched West Australian Current (Wells and Wells, 1994) versus the Leeuwin Current through critical periods in the Pleistocene such as the Middle Pleistocene Transition (MPT).

Sites U1461 and U1462 (Figures F1, F15) in the NCB are near a series of drowned reefs at $\sim 22^{\circ} \mathrm{S}$. The purpose of drilling these sites was to obtain an in situ record of ITF connectivity over the last $5 \mathrm{My}$ and determine the timing of reef development. Both sites yielded well-constrained biostratigraphic and magnetostratigraphic ages and detailed well logs (Figure F17), including both downhole log and core-based sonic velocity data (Figure F18). These data will allow regional seismic profiles to be calibrated in detail for the first time and enable dating of reflectors beneath these reefs, thereby constraining their onset. Because Site U1464 in the Roebuck Basin is updip from a drowned shoal (Ryan et al., 2009), drilling has revealed a detailed biochronostratigraphic framework with which to date the initiation and demise of this "failed" Rowley Shoal (Figure F1). Horizons of Indo-Pacific benthic foraminifers were common in Pliocene-Pleistocene strata at Sites U1461 and U1462, as well as at Sites U1463 and U1464 farther north and may also be present in the Pleistocene strata of southern Sites U1459 and U1460. The relative abundance of these biogeographically significant Indo-Pacific foraminifers (Figure F16) is related to intermittent ITF connectivity (Gallagher et al., 2009). Furthermore, the modern distribution of some of these taxa extends to Cape Leeuwin (at $\sim 34^{\circ} \mathrm{S}$; Li et al., 1999) and is related directly to the path of the warm Leeuwin Current. Similarly, the spatial and temporal distributions of biogeographically important Indo-Pacific macrofossils (corals and mollusks), ostracods, and dinoflagellates reflect ITF connectivity. Detailed studies of the abundance of all of these fossils will shed light on the secular variations in ITF connectivity over the last $5 \mathrm{My}$. Studies on the distribution of these fossil groups in the Miocene shallow-water strata cored at Site U1464 will improve our knowledge of the biogeographic consequences of ITF restriction at $\sim 10$ $\mathrm{Ma}$, preceding the onset of the ITF connectivity near the base of the Pliocene (Kuhnt et al., 2004).

Previous work (Gallagher et al., 2014b) has shown that marine ooids are present in the strata adjacent to Sites U1461 and U1462. Their presence indicates that shallow-water, carbonate-supersaturated, arid, tropical conditions prevailed during the Pleistocene in the region. However, their ages and regional stratigraphic setting are not well constrained, because they were present only in cuttings from sparsely sampled petroleum industry wells (Gallagher et al., 2014b). Expedition 356 coring has revealed Pleistocene ooids at Sites U1461 and U1462. Further analyses will constrain the ages of these key tropical indexes and enhance our understanding of the onset of aridity and reef development in northwestern Australia.

2. Obtain an $\sim 5$ My orbital-scale tropical to subtropical climate and ocean archive, directly comparable to deep-ocean oxygen isotope and ice-core archives, to chart the variability of the Australian monsoon and the onset of aridity in northwestern Australia.

There are no well-constrained orbital-scale climate records beyond 500,000 y (Kawamura et al., 2006; van der Kaars et al., 2006) 
Figure F15. Summary of lithology and unit boundaries for each site, Expedition 356. Ages were determined from biostratigraphy.

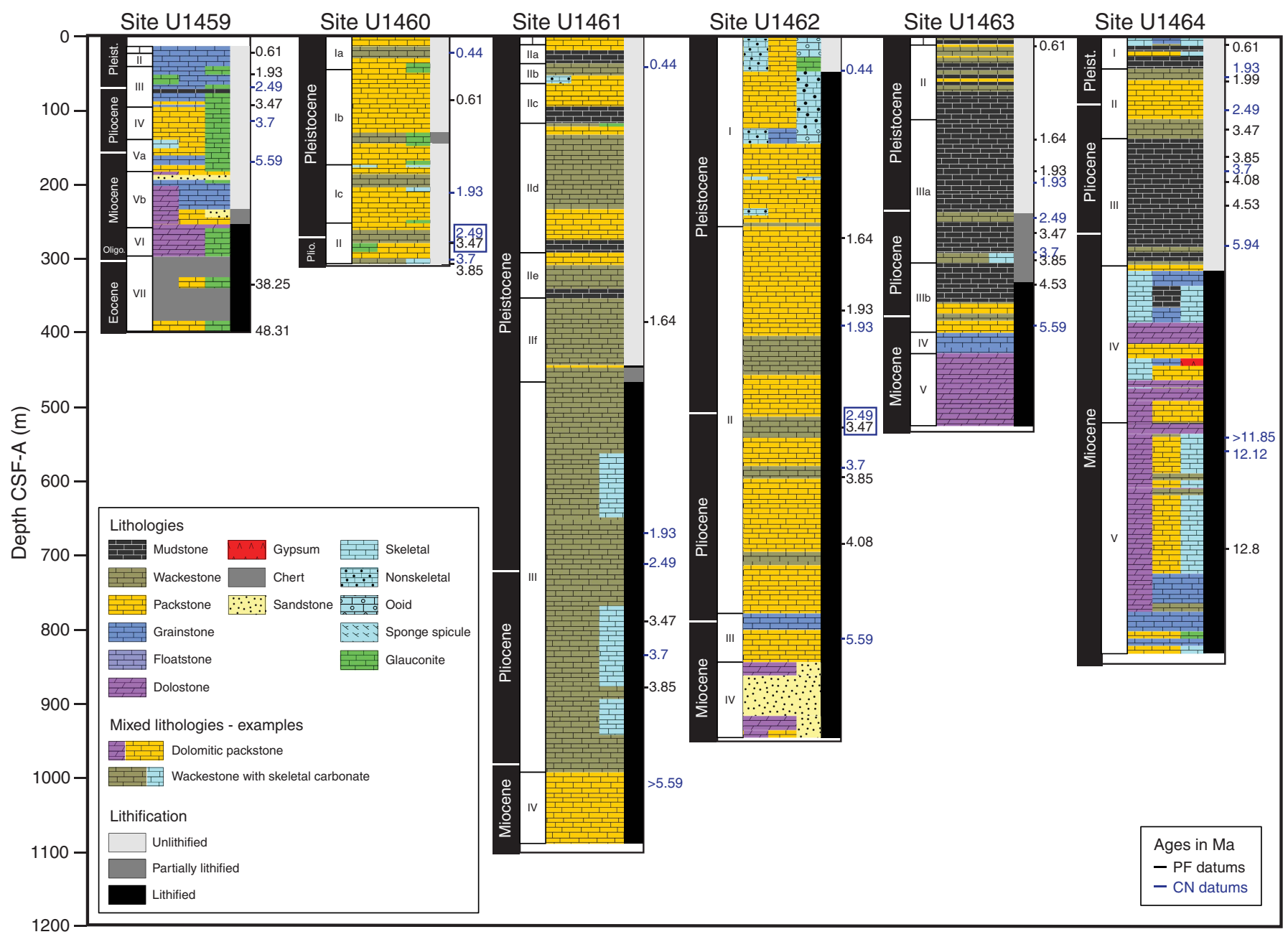

along the entire western margin of Australia. To address this gap in our understanding, Sites U1458-U1460 were targeted to obtain a 5 My record of the southern Australian winter-dominated rainfall regime of Australia. The more northerly sites (U1461-U1464) were targeted to reveal the equivalent record of the summer rainfalldominated Australian monsoon for this period. All sites lie on the shelf or upper slope and it was anticipated that these "proximal" records would preserve more continent-derived siliciclastics (Figures F19, F20) compared to the more distal deeper oceanic ODP and Deep Sea Drilling Project (DSDP) sites in the Indian Ocean nearby.

Because Sites U1459 and U1460 yielded a sequence of Miocene to Quaternary shelf to upper bathyal carbonates, further research on the clay mineralogy and pollen record of the thick $(270 \mathrm{~m})$ highrecovery (98\%) Pleistocene section at Site U1460 is likely to yield a 2 My orbital-scale climate record of the winter-dominated rainfall regime (Figure F17). When combined with similar research on the high-recovery Pliocene record at Site U1459, this will greatly increase our understanding of how Australia's subtropical to warm temperate climate responded to Pliocene warmth through to the MPT and onset of Late Pleistocene to recent icehouse conditions.

Site U1461 yielded the thickest sequence of Pliocene to Pleistocene strata obtained during this expedition $(1000 \mathrm{~m})$. This, together with its excellent recovery (83\%) and the very good preservation of the calcareous microfossils within these strata, means that it is po- tentially one of the best sampled paleoceanographic and climate archives along the western continental margin of Australia. Another archive with excellently preserved calcareous microfossils was cored at Site U1463. The only other comparable records to these sites in this region are the deep oceanic archives from DSDP Site 214 and ODP Site 763A (see Karas et al., 2009, 2011). The very good preservation of foraminifers (Figure F21) in the Pleistocene (Site U1463) and Pliocene (Sites U1461 and U1463) is likely to facilitate orbital-scale paleoceanographic and paleoclimate reconstructions using stable $\mathrm{C} / \mathrm{O}$ isotopes and $\mathrm{Mg} / \mathrm{Ca}$ analyses. Results from Site U1463 also suggest organic biomarker analyses may be successfully applied to this section. The combination of inorganic (elemental/isotopic) and organic geochemical analyses of Site U1463 is likely to reveal an unparalleled $5 \mathrm{My}$ record of oceanic conditions immediately downstream of the ITF.

There are significantly more siliciclastics in the Pliocene strata compared to the Pleistocene at Sites U1461-U1464 (Figures F17, F19). Analyses of the pollen content, clay mineralogy, and other siliciclastic content (such as dust) at these sites will reveal variations in terrestrial input directly associated with the relative strength of the Australian monsoon over the last $5 \mathrm{My}$ and the switch to more arid conditions during the Pleistocene. The presence of anhydrite in the underlying Miocene strata at Sites U1462-U1464 suggests that drier, more arid conditions prevailed before Australian monsoon in- 
Figure F16. A. Summary of benthic foraminiferal assemblages for each site, Expedition 356. Ages were determined from biostratigraphy. Benthic foraminiferal assemblages were smoothed to generate this regional synthesis, resulting in slight differences from data presented in both hole and site summaries (see each site chapter for more detail). (Continued on next page.)

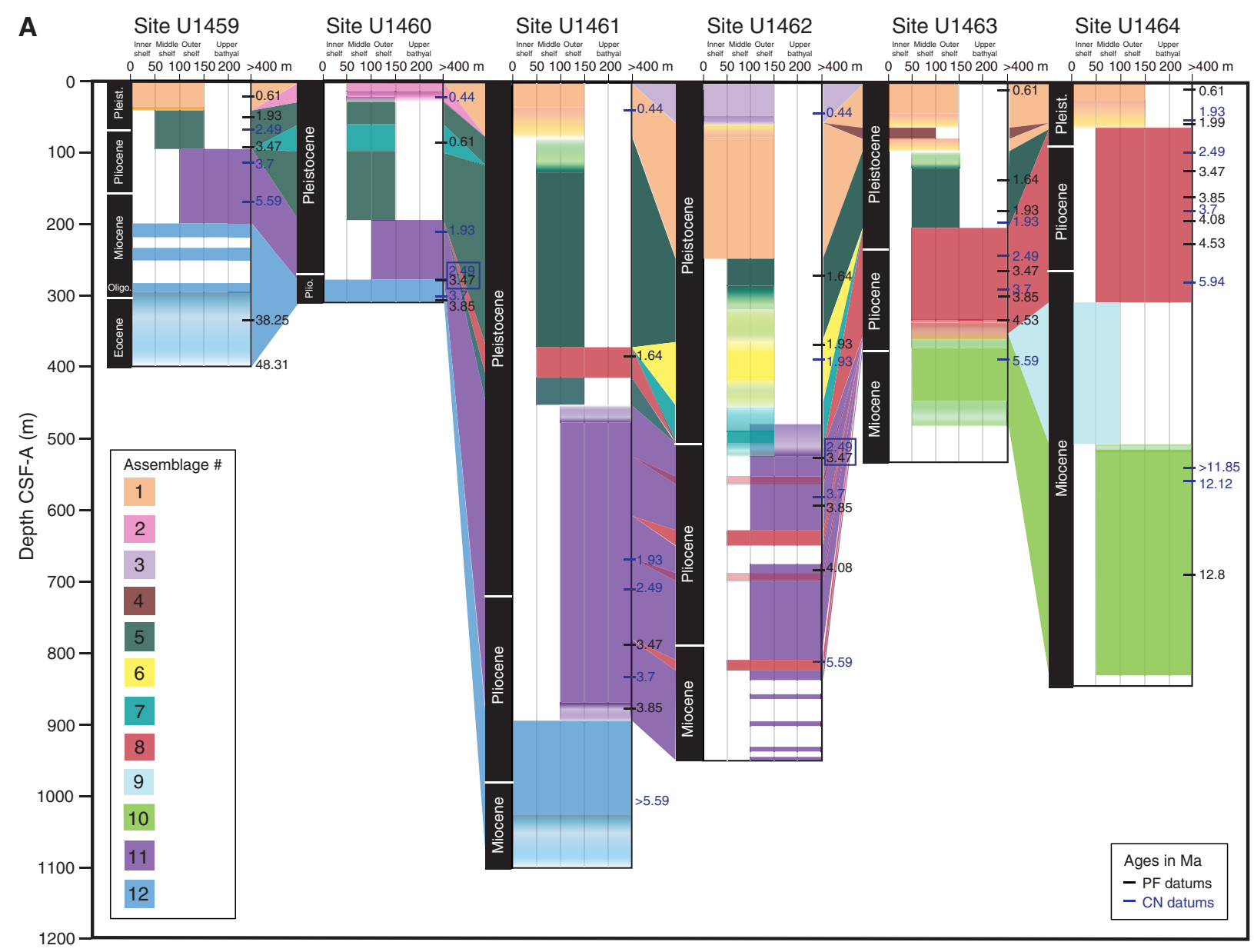

tensification during the Pliocene and has led to elevated salinities in the pore waters in the overlying sediment (Figure F22).

\section{Provide empirical input into the spatiotemporal patterns of sub- sidence along the NWS that can be used to place fundamental constraints on the interaction between Australian plate motion and mantle convection and to ground truth geodynamic models.}

Coring a latitudinal transect of seven sites from $29^{\circ} \mathrm{S}$ to $18^{\circ} \mathrm{S}$ has provided a well-constrained stratigraphic framework (Figures F1, F15) that will allow construction of a series of high-resolution subsidence curves. Such analyses will draw on the detailed physical properties data from both laboratory and wireline logging measurements of such lithology-dependent properties as density and porosity. These data will be combined with age models and paleobathymetry from each site. Paleobathymetric estimation will follow a holistic approach involving benthic foraminiferal assemblages (Figure F16), planktonic percentage, and sedimentary facies, further enhanced using estimates from larger foraminifer distributions and consideration of seismic geometries.

Calculation of 1-D water-loaded basement subsidence histories at each site assuming Airy isostasy should be sufficient for our pur- poses. The abundance of industry seismic profiles near several of the sites would enable flexural backstripping, but the low flexural rigidity of the region in light of the apparent long-wavelength character of the subsidence renders this degree of complexity unnecessary. Expedition 356 coring provides well-defined records of paleobathymetry (Figure F16), sediment compaction parameters, and lithology (Figure F15) for the last 5 My. Such parameters are also needed for the underlying sedimentary units, whose compaction accounts for a large component of the accommodation space, but these data are available from the nearby commercial wells.

Construction of subsidence curves along our latitudinal transect will constrain the spatial and temporal patterns of vertical motions caused by the interaction between plate motion and convection within the Earth's mantle, known as dynamic topography. The NWS is an ideal location to study this phenomenon because it is positioned on the fastest moving continent since the Eocene, on the edge of the degree 2 geoid anomaly. Accurate subsidence analyses over $10^{\circ}$ of latitude can resolve whether northern Australia is moving with/over a time-transient or long-term stationary downwelling within the mantle, thereby vastly improving our understanding of deep-Earth dynamics and their impact on surficial processes. 
Figure F16 (continued). B. Taxa and assemblage key.

B Expedition 356 preliminary benthic foraminifer sssemblage descriptions

\begin{tabular}{|c|c|c|c|}
\hline Assemblage & Sites found & Paleodepth estimate ${ }^{\star}$ & $\begin{array}{l}\text { Common dominant species } \\
\text { (in rough abundance order) }\end{array}$ \\
\hline 1 & $\begin{array}{l}\text { U1459, U1461, } \\
\text { U1562, U1463, } \\
\text { and U1464 }\end{array}$ & $\begin{array}{l}\text { Inner to outer shelf } \\
(0 \text { to } 150 \mathrm{~m})\end{array}$ & $\begin{array}{l}\text { Quinqueloculina spp., Textularia spp., Sahulia } \\
\text { barkeri, Triloculina spp., Sagrinella jugosa, } \\
\text { Discorbinella spp., Amphistegina spp., } \\
\text { Cibicidoides spp., and Operculina spp. }\end{array}$ \\
\hline 2 & U1460 & $\begin{array}{l}\text { Middle shelf to upper } \\
\text { bathyal ( } 50 \text { to }>400 \mathrm{~m} \text { ) }\end{array}$ & $\begin{array}{l}\text { Uvigerina peregrina, Siphogenerina spp., } \\
\text { Cibicidoides spp., and Miliolina spp. }\end{array}$ \\
\hline 3 & U1462 & $\begin{array}{l}\text { Inner to outer shelf } \\
(0 \text { to } 150 \mathrm{~m})\end{array}$ & $\begin{array}{l}\text { Operculina spp., Cibicidoides spp., Elphidium } \\
\text { spp., Ammonia spp., and Discorbinella spp. }\end{array}$ \\
\hline 4 & U1463 & $\begin{array}{l}\text { Inner to middle shelf } \\
(0 \text { to } 100 \mathrm{~m})\end{array}$ & Operculina spp. and Amphistegina spp. \\
\hline 5 & $\begin{array}{l}\mathrm{U} 1459, \mathrm{U} 1460 \\
\mathrm{U} 1461, \mathrm{U} 1462, \\
\text { and } \mathrm{U} 1463\end{array}$ & $\begin{array}{l}\text { Inner to outer shelf } \\
(0 \text { to } 150 \mathrm{~m})\end{array}$ & $\begin{array}{l}\text { Cibicidoides spp., Bolivina spp., Brizalina spp., } \\
\text { Discorbinella spp., Melonis spp., Amphistegina } \\
\text { spp., and Elphidium spp. }\end{array}$ \\
\hline 6 & U1462 & $\begin{array}{l}\text { Middle to outer shelf } \\
\text { (50 to } 150 \mathrm{~m} \text { ) }\end{array}$ & $\begin{array}{l}\text { Lenticulina spp., Brizalina spp., Bolivina spp., } \\
\text { and Cibicidoides spp. }\end{array}$ \\
\hline 7 & $\begin{array}{l}\text { U1460 and } \\
\text { U1462 }\end{array}$ & $\begin{array}{l}\text { Middle to outer shelf } \\
\text { (50 to } 150 \mathrm{~m})\end{array}$ & $\begin{array}{l}\text { Siphogenerina raphana, Bolivina spp., and } \\
\text { Brizalina spp. }\end{array}$ \\
\hline 8 & $\begin{array}{l}\text { U1461, U1462, } \\
\text { U1463, and } \\
\text { U1464 }\end{array}$ & $\begin{array}{l}\text { Middle shelf to upper } \\
\text { bathyal (50 to }>400 \mathrm{~m} \text { ) }\end{array}$ & $\begin{array}{l}\text { Lenticulina spp., Neoeponides spp., } \\
\text { Pseudorotalia spp., Textularia spp., } \\
\text { Planorbulinella larvata, Clavulina subangularis, } \\
\text { Elphidium spp., Bolivina spp., Cibicidoides spp., } \\
\text { and Rotalinoides spp. } \\
\end{array}$ \\
\hline 9 & $\begin{array}{l}\text { U1463 and } \\
\text { U1464 }\end{array}$ & $\begin{array}{l}\text { Inner to middle shelf } \\
(0 \text { to } 100 \mathrm{~m})\end{array}$ & $\begin{array}{l}\text { Amphistegina spp., Operculina spp., Elphidium } \\
\text { craticulatum, Planorbulinella spp., and } \\
\text { Sphaerogypsina spp. }\end{array}$ \\
\hline 10 & $\begin{array}{l}\text { U1463 and } \\
\text { U1464 }\end{array}$ & $\begin{array}{l}\text { Middle shelf to upper } \\
\text { bathyal ( } 50 \text { to }>400 \mathrm{~m} \text { ) }\end{array}$ & $\begin{array}{l}\text { Cibicidoides spp., Elphidium spp., Amphistegina } \\
\text { spp., Operculina spp., Anomalinoides spp., } \\
\text { Borelis spp., Nephrolepidina spp., and } \\
\text { Tribliolepidina spp. }\end{array}$ \\
\hline 11 & $\begin{array}{l}\text { U1459, U1460, } \\
\text { U1461, and } \\
\text { U1462 }\end{array}$ & $\begin{array}{l}\text { Outer shelf to upper } \\
\text { bathyal }(100 \text { to }>400 \mathrm{~m})\end{array}$ & $\begin{array}{l}\text { Uvigerina peregrina, Bolivina spp., Brizalina } \\
\text { spp., Heterolepa spp., Cibicidoides spp., and } \\
\text { Laevidentalina spp. }\end{array}$ \\
\hline 12 & $\begin{array}{l}\text { U1459, U1460, } \\
\text { and U1461 }\end{array}$ & $\begin{array}{l}\text { Inner shelf to upper } \\
\text { bathyal }(0 \text { to }>400 \mathrm{~m})\end{array}$ & $\begin{array}{l}\text { Cibicidoides spp. with only one or two other } \\
\text { species (preservation is always poor) }\end{array}$ \\
\hline
\end{tabular}

* Please note that paleodepth ranges are for ALL encountered taxa, including those likely transported from more shallow depths. 
Figure F17. Expedition 356 NGR, as measured on whole-round cores and during wireline logging. Wireline data have been offset by $20 \mathrm{gAPI}$ for plotting. Ages were determined from biostratigraphy.

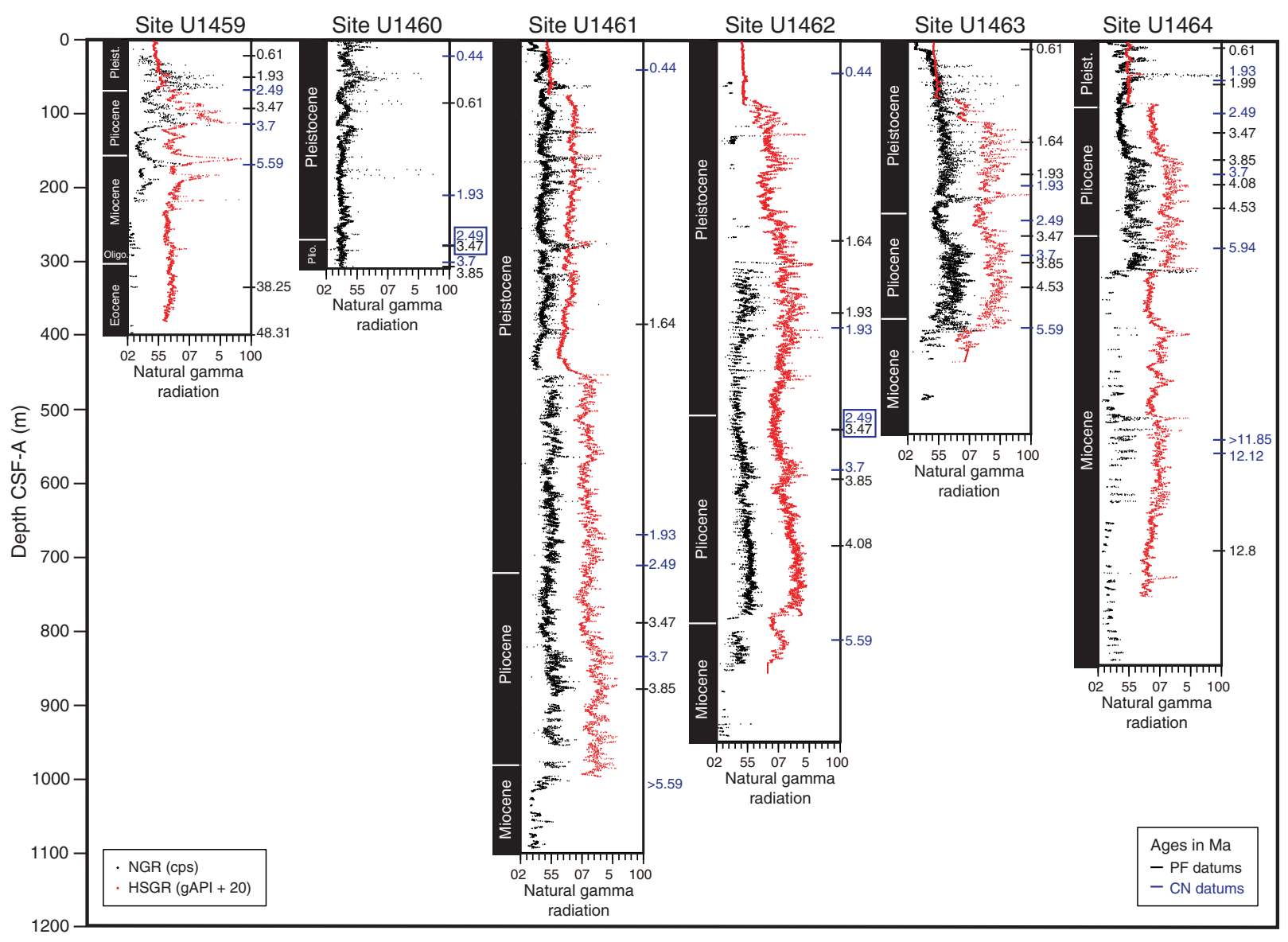


Figure F18. Expedition $356 P$-wave velocity, as measured on discrete core samples using the $P$-wave caliper from each site.

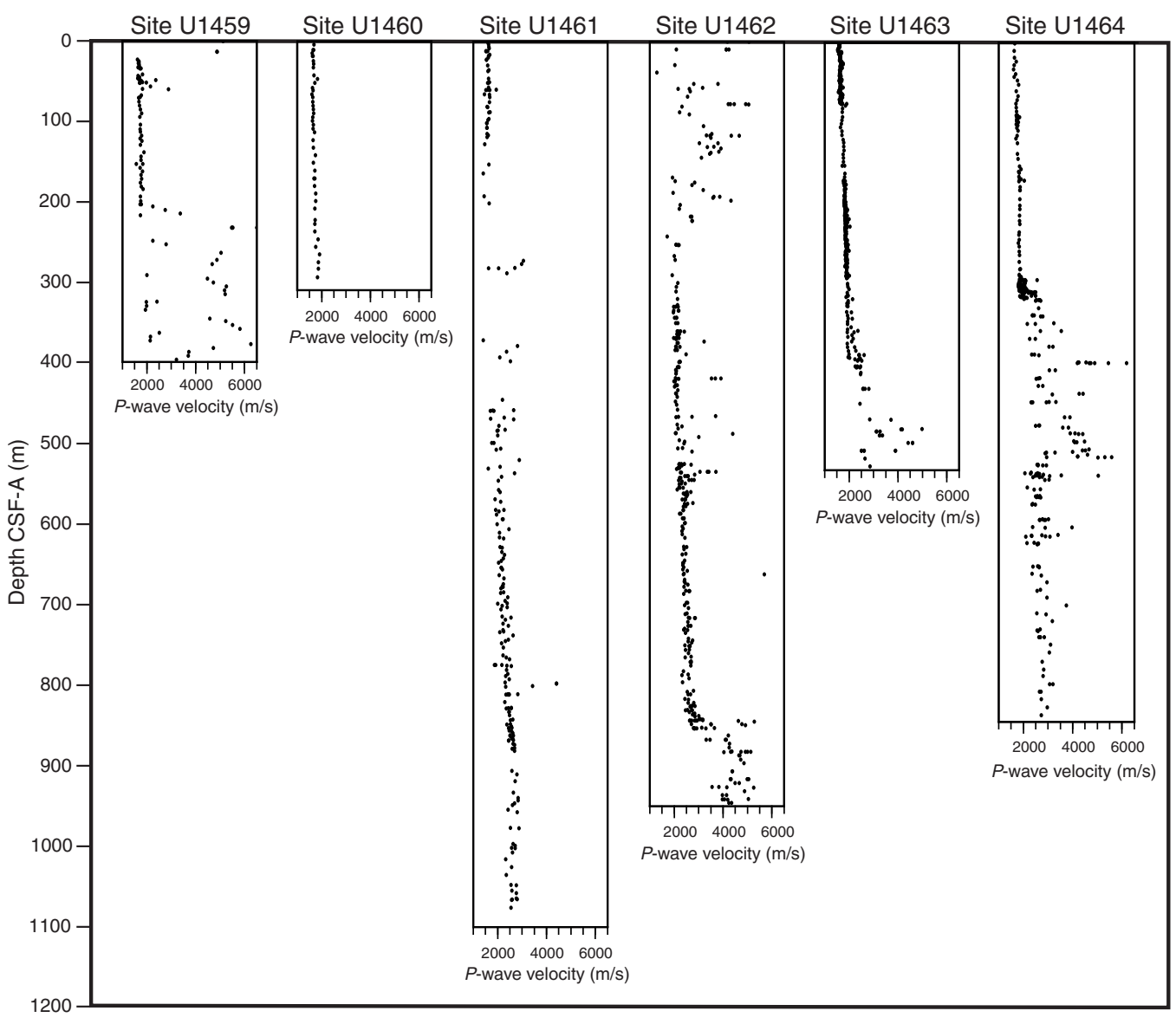


Figure F19. Quartz component percent estimates from smear slide data for each site, Expedition 356. Ages were determined from biostratigraphy.

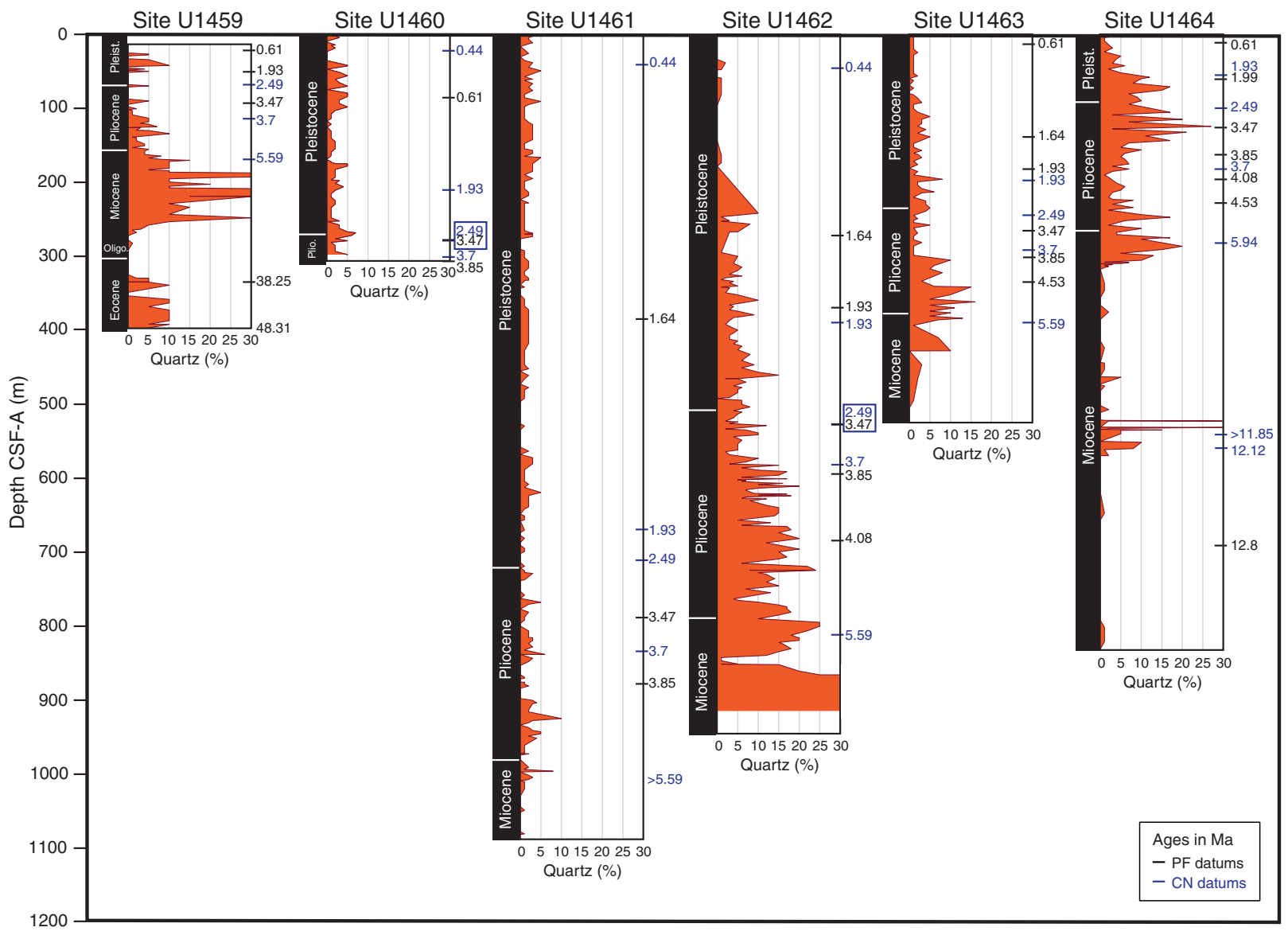


Figure F20. Carbonate percent from coulometry analyses for each site, Expedition 356. Ages were determined from biostratigraphy.

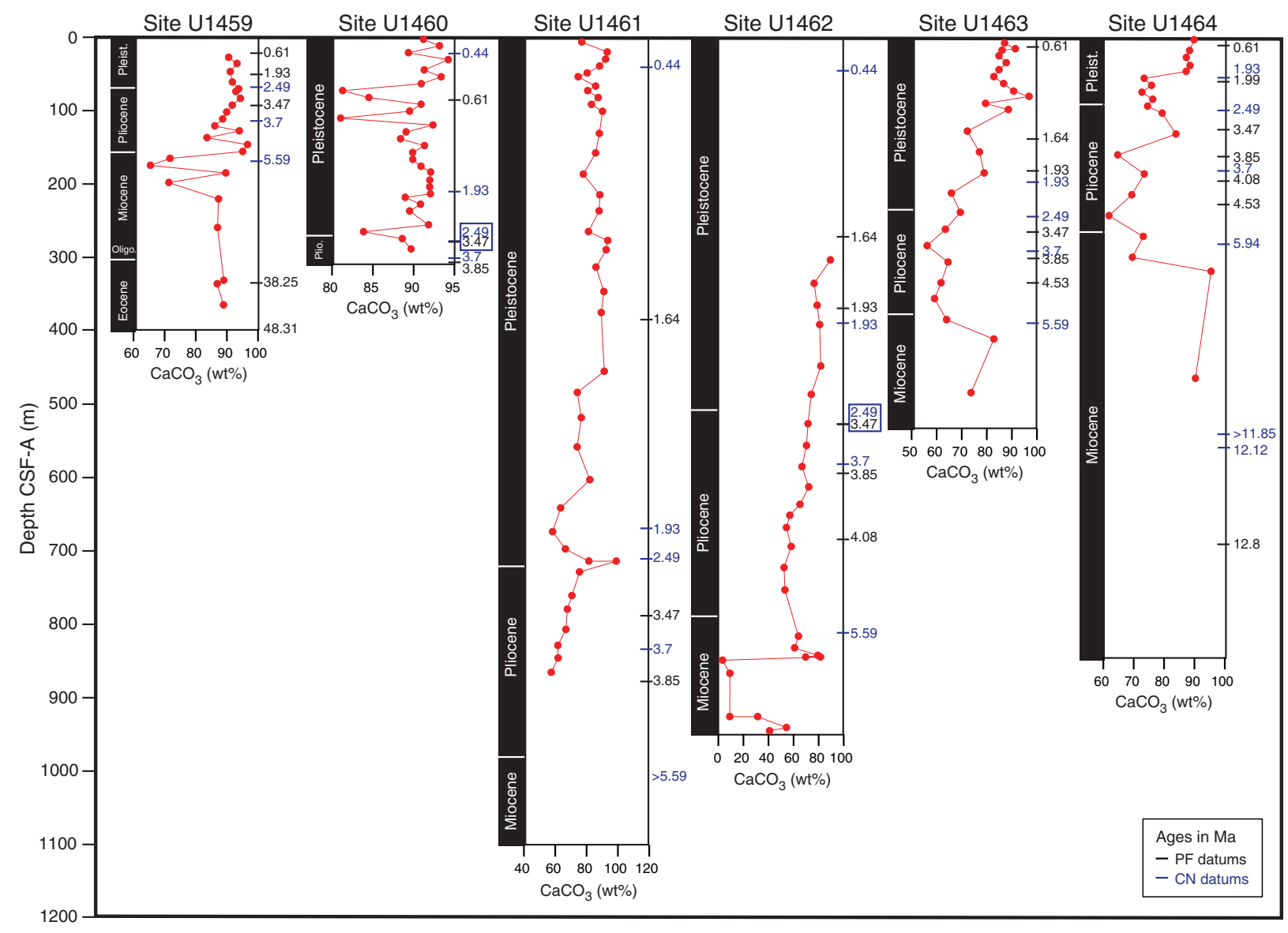


Figure F21. Scanning electron microscope photomicrographs of typical preservation states of planktonic foraminifers, Site U1463. The depicted species is Globigerinoides sacculifer (or closely related to G. sacculifer). Depths are in CSF-A.

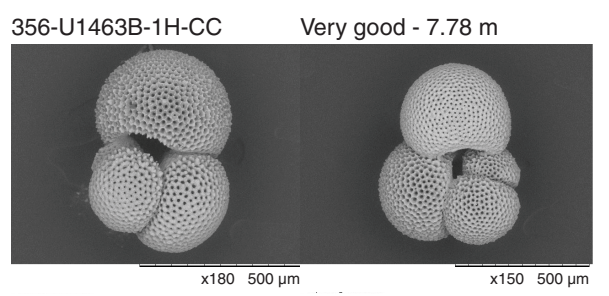

356-U1463C-6H-CC Moderate $-51.66 \mathrm{~m}$

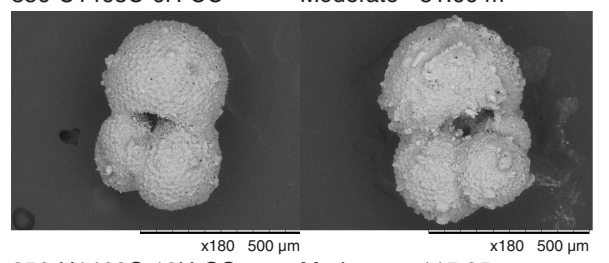

356-U1463C-13H-CC Moderate $-115.85 \mathrm{~m}$

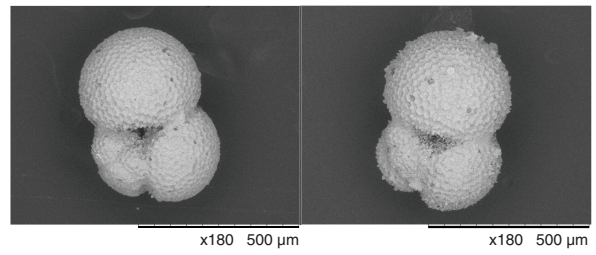

356-U1463C-20H-CC Moderate-182.19 m

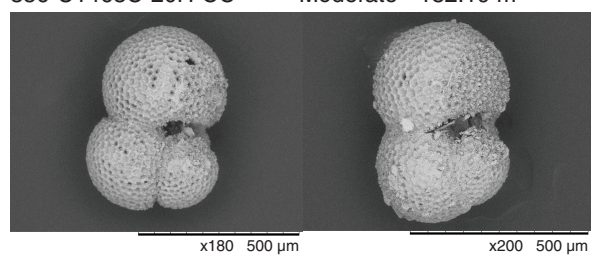

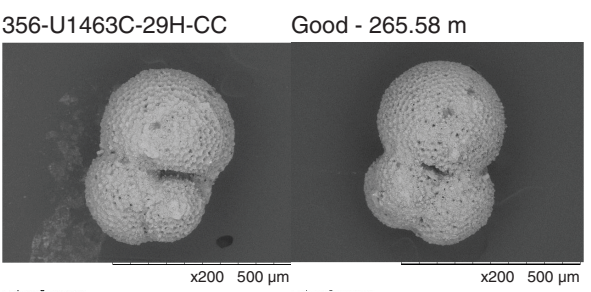

356-U1463C-40F-2 Good-314.42 m

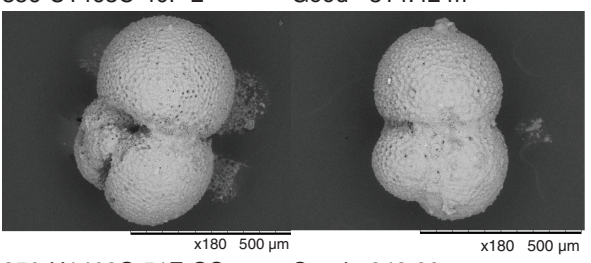

356-U1463C-51F-CC

Good - 349.80 m

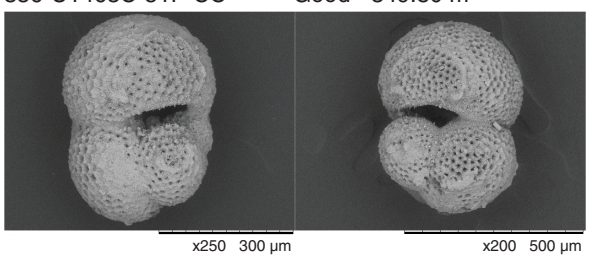

356-U1463C-61F-CC Moderate - 392.44 m

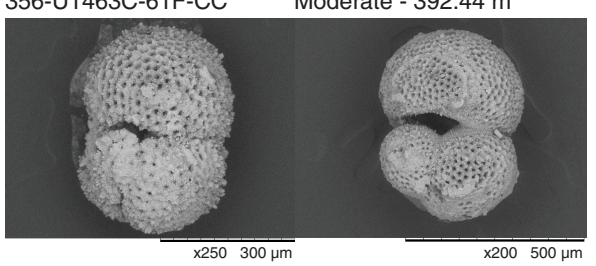


Figure F22. Sulfate, calcium, and salinity concentrations in interstitial water samples for each site, Expedition 356. Ages were determined from biostratigraphy.

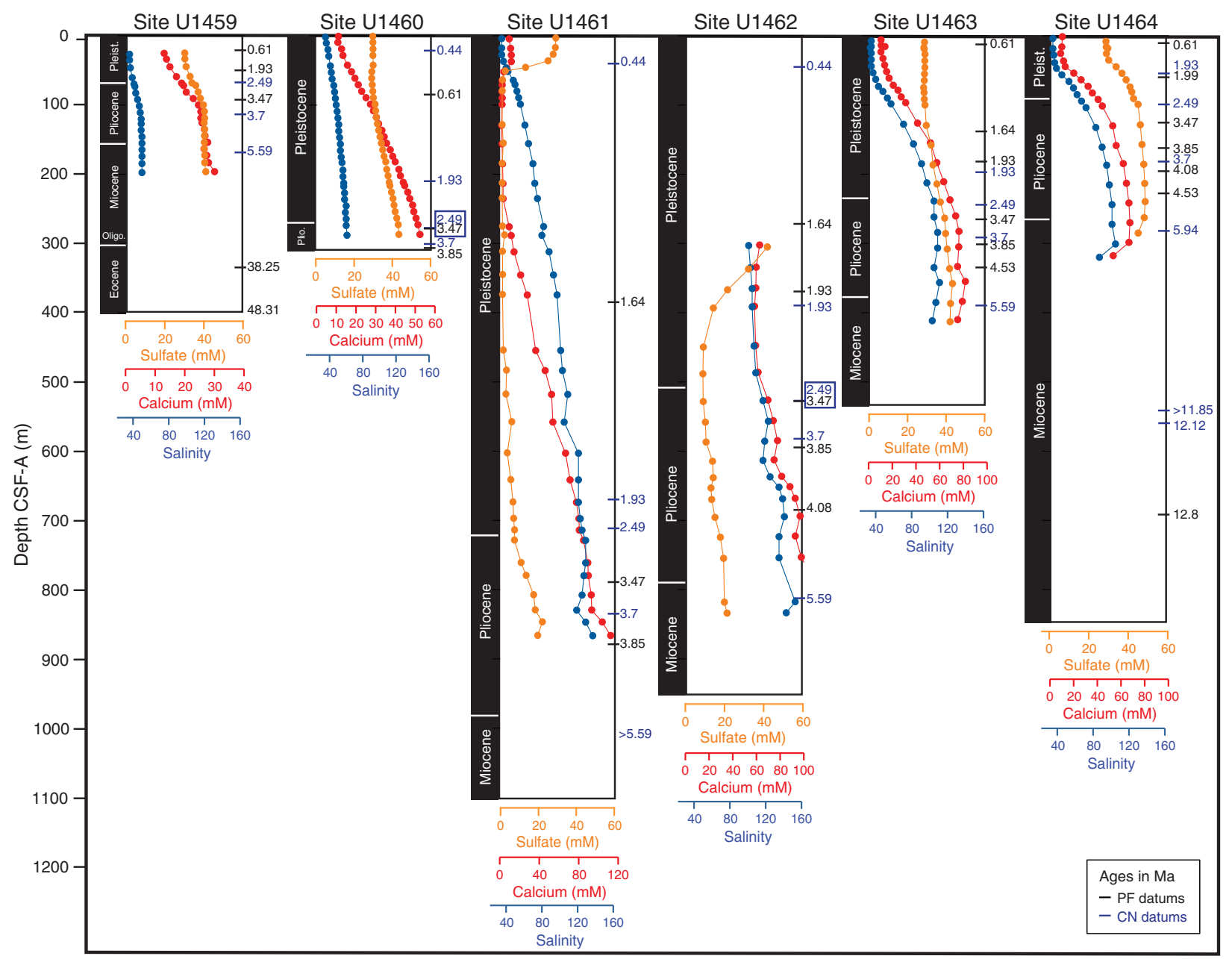

\section{References}

An, Z., 2000. The history and variability of the east Asian paleomonsoon climate. Quaternary Science Reviews, 19(1-5):171-187. http://dx.doi.org/10.1016/S0277-3791(99)00060-8

Audley-Charles, M.G., Ballantyne, P.D., and Hall, R., 1988. Mesozoic-Cenozoic rift-drift sequence of Asian fragments from Gondwanaland. Tectonophysics, 155(1-4):317-330. http://dx.doi.org/10.1016/0040-1951(88)90272-7

Beaufort, L., van der Kaars, S., Bassinot, F.C., and Moron, V., 2010. Past dynamics of the Australian monsoon: precession, phase and links to the global monsoon concept. Climate of the Past, 6(5):695-706. http://dx.doi.org/10.5194/cp-6-695-2010

Boote, D.R.D., and Kirk, R.B., 1989. Depositional wedge cycles on an evolving plate margin, western and northwestern Australia. AAPG Bulletin, 73(2):216-243.

Bowman, D.M.J.S., Brown, G.K., Braby, M.F., Brown, J.R., Cook, L.G., Crisp, M.D., Ford, F., Haberle, S., Hughes, J., Isagi, Y., Joseph, L., McBride, J., Nelson, G., and Ladiges, P.Y., 2010. Biogeography of the Australian monsoon tropics. Journal of Biogeography, 37(2):201-216. http://dx.doi.org/10.1111/j.1365-2699.2009.02210.x

Carter, R.M., and Gammon, P., 2004. New Zealand maritime glaciation: millennial-scale southern climate change since 3.9 Ma. Science, 304(5677):1659-1662. http://dx.doi.org/10.1126/science.1093726

Cathro, D.L., Austin, J.A., Jr., and Moss, G.D., 2003. Progradation along a deeply submerged Oligocene-Miocene heterozoan carbonate shelf: how sensitive are clinoforms to sea level variations? AAPG Bulletin 87(10):1547-1574. http://dx.doi.org/10.1306/05210300177

Collins, L.B., 2002. Tertiary foundations and Quaternary evolution of coral reef systems of Australia's North West shelf. In Keep, M., and Moss, S.J. (Eds.), The Sedimentary Basins of Western Australia (Volume 3): Perth, Australia (Petroleum Exploration Society of Australia), 129-152.

Collins, L.B., James, N.P., and Bone, Y., 2014. Carbonate shelf sediments of the western continental margin of Australia. In Chiocci, F.L., and Chivas, A.R. (Eds.), Continental Shelves of the World: Their Evolution During the Last Glacio-Eustatic Cycle. Memoirs - Geological Society of London, 41:255272. http://dx.doi.org/10.1144/M41.19

Collins, L.B., and Testa, V., 2010. Quaternary development of resilient reefs on the subsiding Kimberley continental margin, Northwest Australia. Brazilian Journal of Oceanography, 58(SPE1):67-77. http://dx.doi.org/10.1590/S1679-87592010000500007

Collins, L.B., Zhao, J.-X., and Freeman, H., 2006. A high-precision record of mid-late Holocene sea-level events from emergent coral pavements in the Houtman Abrolhos Islands, southwest Australia. Quaternary International, 145-146:78-85. http://dx.doi.org/10.1016/j.quaint.2005.07.006

Collins, L.B., Zhu, Z.R., Wyrwoll, K.-H., Hatcher, B.G., Playford, P.E., Eisenhauer, A., Chen, J.H., Wasserburg, G.J., and Bonani, G., 1993. Holocene growth history of a reef complex on a cool-water carbonate margin: Easter Group of the Houtman Abrolhos, Eastern Indian Ocean. Marine Geology, 115(1-2):29-46.

http://dx.doi.org/10.1016/0025-3227(93)90073-5 
Cresswell, G.R., 1991. The Leeuwin Current: observations and recent models Journal of the Royal Society of Western Australia, 74:1-14.

Crisp, M.D. and Cook, L.G., 2013. How was the Australian flora assembled over the last 65 million years? A molecular perspective. Annual Review of Ecology, Evolution, and Systematics, 44(1):303-324. http://dx.doi.org/10.1146/annurev-ecolsys-110512-135910

Czarnota, K., Hoggard, M.J., White, N., and Winterbourne, J., 2013. Spatial and temporal patterns of Cenozoic dynamic topography around Australia. Geochemistry, Geophysics, Geosystems, 14(3):634-658. http://dx.doi.org/10.1029/2012GC004392

de Garidel-Thoron, T., Rosenthal, Y., Bassinot, F., and Beaufort, L., 2005. Stable sea surface temperatures in the Western Pacific Warm Pool over the past 1.75 million years. Nature, 433(7023):294-298. http://dx.doi.org/10.1038/nature03189

deMenocal, P.B., Bristow, J.F., and Stein, R., 1992. Paleoclimatic applications of downhole logs: Pliocene-Pleistocene results from Hole 798B, Sea of Japan. In Pisciotto, K.A., Ingle, J.C., Jr., von Breymann, M.T., Barron, J., et al., Proceedings of the Ocean Drilling Program, Scientific Results, 127/128 (Part 1): College Station, TX (Ocean Drilling Program), 393-406. http://dx.doi.org/10.2973/odp.proc.sr.127128-1.143.1992

DiCaprio, L., Gurnis, M., and Müller, R.D., 2009. Long-wavelength tilting of the Australian continent since the Late Cretaceous. Earth and Planetary Science Letters, 278(3-4):175-185. http://dx.doi.org/10.1016/j.epsl.2008.11.030

DiCaprio, L., Gurnis, M., Müller, R.D., and Tan, E., 2011. Mantle dynamics of continentwide Cenozoic subsidence and tilting of Australia. Lithosphere, 3(5):311-316. http://dx.doi.org/10.1130/L140.1

Driscoll, N.W., and Karner, G.D., 1998. Lower crustal extension across the Northern Carnarvon Basin, Australia: evidence for an eastward dipping detachment. Journal of Geophysical Research: Solid Earth, 103(B3):49754991. http://dx.doi.org/10.1029/97JB03295

Dyksterhuis, S., Müller, R.D., and Albert, R.A., 2005. Paleostress field evolution of the Australian continent since the Eocene. Journal of Geophysical Research: Solid Earth, 110(B5):B05102. http://dx.doi.org/10.1029/2003JB002728

Ehrenberg, S.N., McArthur, J.M., and Thirlwall, M.F., 2006. Growth, demise, and dolomitization of Miocene carbonate platforms on the Marion Plateau, offshore NE Australia. Journal of Sedimentary Research, 76:91-116. http://dx.doi.org/10.2110/jsr.2006.06

Etheridge, M.A., and O'Brian, G.W., 1994. Structural and tectonic evolution of the Western Australian margin basin system. Petroleum Exploration Society of Australia Journal, 22:45-63.

Exon, N.F., and Colwell, J.B., 1994. Geological history of the outer North West shelf of Australia: a synthesis. AGSO Journal of Australian Geology and Geophysics, 15(1):177-190.

Fujioka, T., and Chappell, J., 2010. History of Australian aridity: chronology in the evolution of landscapes. Geological Society Special Publication, 346(1):121-139. http://dx.doi.org/10.1144/SP346.8

Gallagher, S.J., Fulthorpe, C.S., and Bogus, K.A., 2014a. Expedition 356 Scientific Prospectus: Reefs, Oceans, and Climate. International Ocean Discovery Program. http://dx.doi.org/10.14379/iodp.sp.356.2014

Gallagher, S.J., Fulthorpe, C.S., Bogus, K., Auer, G., Baranwal, S., Castañeda, I.S., Christensen, B.A., De Vleeschouwer, D., Franco, D.R., Groeneveld, J., Gurnis, M., Haller, C., He, Y., Henderiks, J., Himmler, T., Ishiwa, T., Iwatani, H., Jatiningrum, R.S., Kominz, M.A., Korpanty, C.A., Lee, E.Y., Levin, E., Mamo, B.L., McGregor, H.V., McHugh, C.M., Petrick, B.F., Potts, D.C., Rastegar Lari, A., Renema, W., Reuning, L., Takayanagi, H., and Zhang, W., 2017a. Expedition 356 methods. In Gallagher, S.J., Fulthorpe, C.S., Bogus, K., and the Expedition 356 Scientists, Indonesian Throughflow. Proceedings of the International Ocean Discovery Program, 356: College Station, TX (International Ocean Discovery Program). http://dx.doi.org/10.14379/iodp.proc.356.102.2017

Gallagher, S.J., Fulthorpe, C.S., Bogus, K., Auer, G., Baranwal, S., Castañeda, I.S., Christensen, B.A., De Vleeschouwer, D., Franco, D.R., Groeneveld, J., Gurnis, M., Haller, C., He, Y., Henderiks, J., Himmler, T., Ishiwa, T., Iwatani, H., Jatiningrum, R.S., Kominz, M.A., Korpanty, C.A., Lee, E.Y., Levin, E., Mamo, B.L., McGregor, H.V., McHugh, C.M., Petrick, B.F.,
Potts, D.C., Rastegar Lari, A., Renema, W., Reuning, L., Takayanagi, H., and Zhang, W., 2017b. Site U1458. In Gallagher, S.J., Fulthorpe, C.S., Bogus, K., and the Expedition 356 Scientists, Indonesian Throughflow. Proceedings of the International Ocean Discovery Program, 356: College Station, TX (International Ocean Discovery Program). http://dx.doi.org/10.14379/iodp.proc.356.103.2017

Gallagher, S.J., Fulthorpe, C.S., Bogus, K., Auer, G., Baranwal, S., Castañeda, I.S., Christensen, B.A., De Vleeschouwer, D., Franco, D.R., Groeneveld, J., Gurnis, M., Haller, C., He, Y., Henderiks, J., Himmler, T., Ishiwa, T., Iwatani, H., Jatiningrum, R.S., Kominz, M.A., Korpanty, C.A., Lee, E.Y., Levin, E., Mamo, B.L., McGregor, H.V., McHugh, C.M., Petrick, B.F., Potts, D.C., Rastegar Lari, A., Renema, W., Reuning, L., Takayanagi, H., and Zhang, W., 2017c. Site U1459. In Gallagher, S.J., Fulthorpe, C.S., Bogus, K., and the Expedition 356 Scientists, Indonesian Throughflow. Proceedings of the International Ocean Discovery Program, 356: College Station, TX (International Ocean Discovery Program). http://dx.doi.org/10.14379/iodp.proc.356.104.2017

Gallagher, S.J., Fulthorpe, C.S., Bogus, K., Auer, G., Baranwal, S., Castañeda, I.S., Christensen, B.A., De Vleeschouwer, D., Franco, D.R., Groeneveld, J., Gurnis, M., Haller, C., He, Y., Henderiks, J., Himmler, T., Ishiwa, T., Iwatani, H., Jatiningrum, R.S., Kominz, M.A., Korpanty, C.A., Lee, E.Y., Levin, E., Mamo, B.L., McGregor, H.V., McHugh, C.M., Petrick, B.F., Potts, D.C., Rastegar Lari, A., Renema, W., Reuning, L., Takayanagi, H., and Zhang, W., 2017d. Site U1460. In Gallagher, S.J., Fulthorpe, C.S., Bogus, K., and the Expedition 356 Scientists, Indonesian Throughflow. Proceedings of the International Ocean Discovery Program, 356: College Station, TX (International Ocean Discovery Program). http://dx.doi.org/10.14379/iodp.proc.356.105.2017

Gallagher, S.J., Fulthorpe, C.S., Bogus, K., Auer, G., Baranwal, S., Castañeda, I.S., Christensen, B.A., De Vleeschouwer, D., Franco, D.R., Groeneveld, J., Gurnis, M., Haller, C., He, Y., Henderiks, J., Himmler, T., Ishiwa, T., Iwatani, H., Jatiningrum, R.S., Kominz, M.A., Korpanty, C.A., Lee, E.Y., Levin, E., Mamo, B.L., McGregor, H.V., McHugh, C.M., Petrick, B.F., Potts, D.C., Rastegar Lari, A., Renema, W., Reuning, L., Takayanagi, H., and Zhang, W., 2017e. Site U1461. In Gallagher, S.J., Fulthorpe, C.S., Bogus, K., and the Expedition 356 Scientists, Indonesian Throughflow. Proceedings of the International Ocean Discovery Program, 356: College Station, TX (International Ocean Discovery Program). http://dx.doi.org/10.14379/iodp.proc.356.106.2017

Gallagher, S.J., Fulthorpe, C.S., Bogus, K., Auer, G., Baranwal, S., Castañeda, I.S., Christensen, B.A., De Vleeschouwer, D., Franco, D.R., Groeneveld, J., Gurnis, M., Haller, C., He, Y., Henderiks, J., Himmler, T., Ishiwa, T., Iwatani, H., Jatiningrum, R.S., Kominz, M.A., Korpanty, C.A., Lee, E.Y., Levin, E., Mamo, B.L., McGregor, H.V., McHugh, C.M., Petrick, B.F., Potts, D.C., Rastegar Lari, A., Renema, W., Reuning, L., Takayanagi, H., and Zhang, W., 2017f. Site U1462. In Gallagher, S.J., Fulthorpe, C.S., Bogus, K., and the Expedition 356 Scientists, Indonesian Throughflow. Proceedings of the International Ocean Discovery Program, 356: College Station, TX (International Ocean Discovery Program). http://dx.doi.org/10.14379/iodp.proc.356.107.2017

Gallagher, S.J., Fulthorpe, C.S., Bogus, K., Auer, G., Baranwal, S., Castañeda, I.S., Christensen, B.A., De Vleeschouwer, D., Franco, D.R., Groeneveld, J., Gurnis, M., Haller, C., He, Y., Henderiks, J., Himmler, T., Ishiwa, T., Iwatani, H., Jatiningrum, R.S., Kominz, M.A., Korpanty, C.A., Lee, E.Y., Levin, E., Mamo, B.L., McGregor, H.V., McHugh, C.M., Petrick, B.F., Potts, D.C., Rastegar Lari, A., Renema, W., Reuning, L., Takayanagi, H., and Zhang, W., 2017g. Site U1463. In Gallagher, S.J., Fulthorpe, C.S., Bogus, K., and the Expedition 356 Scientists, Indonesian Throughflow. Proceedings of the International Ocean Discovery Program, 356: College Station, TX (International Ocean Discovery Program). http://dx.doi.org/10.14379/iodp.proc.356.108.2017

Gallagher, S.J., Fulthorpe, C.S., Bogus, K., Auer, G., Baranwal, S., Castañeda, I.S., Christensen, B.A., De Vleeschouwer, D., Franco, D.R., Groeneveld, J., Gurnis, M., Haller, C., He, Y., Henderiks, J., Himmler, T., Ishiwa, T., Iwatani, H., Jatiningrum, R.S., Kominz, M.A., Korpanty, C.A., Lee, E.Y., Levin, E., Mamo, B.L., McGregor, H.V., McHugh, C.M., Petrick, B.F., Potts, D.C., Rastegar Lari, A., Renema, W., Reuning, L., Takayanagi, H., 
and Zhang, W., 2017h. Site U1464. In Gallagher, S.J., Fulthorpe, C.S., Bogus, K., and the Expedition 356 Scientists, Indonesian Throughflow. Proceedings of the International Ocean Discovery Program, 356: College Station, TX (International Ocean Discovery Program). http://dx.doi.org/10.14379/iodp.proc.356.109.2017

Gallagher, S.J., Kitamura, A., Iryu, Y., Itaki, T., Koizumi, I., and Hoiles, P.W., 2015. The Pliocene to recent history of the Kuroshio and Tsushima Currents: a multiproxy approach. Progress in Earth and Planetary Science, 2(1):17. http://dx.doi.org/10.1186/s40645-015-0045-6

Gallagher, S.J., Wallace, M.W., Hoiles, P.W., and Southwood, J.M., 2014b. Seismic and stratigraphic evidence for reef expansion and onset of aridity on the Northwest shelf of Australia during the Pleistocene. Marine and Petroleum Geology, 57:470-481. http://dx.doi.org/10.1016/j.marpetgeo.2014.06.011

Gallagher, S.J., Wallace, M.W., Li, C.L., Kinna, B., Bye, J.T., Akimoto, K., and Torii, M., 2009. Neogene history of the West Pacific Warm Pool, Kuroshio and Leeuwin Currents. Paleoceanography, 24(1):PA1206. http://dx.doi.org/10.1029/2008PA001660

Gentilli, J., 1972. Australian Climate Patterns: Melbourne, Australia (Thomas Nelson).

Gingele, F.X., De Deckker, P., and Hillenbrand, C.-D., 2001a. Clay mineral distribution in surface sediment between Indonesia and NW Australiasource and transport by ocean currents. Marine Geology, 179(3-4):135146. http://dx.doi.org/10.1016/S0025-3227(01)00194-3

Gingele, F.X., De Deckker, P., and Hillenbrand, C.-D., 2001b. Late Quaternary fluctuations of the Leeuwin Current and palaeoclimates on the adjacent landmasses: clay mineral evidence. Australian Journal of Earth Sciences, 48(6):867-874. http://dx.doi.org/10.1046/j.1440-0952.2001.00905.x

Goncharov, A., 2004. Basement and crustal structure of the Bonaparte and Browse Basins, Australian northwest margin. In Ellis, G., Baillie, P., and Munson, T. (Eds.), Timor Sea Petroleum Geoscience, Proceedings of the Timor Sea Symposium. Special Publication-Northern Territory Geological Survey, 551-566. http://www.ga.gov.au/webtemp/image_cache/GA8880.pdf

Gordon, A.L., 2005. Oceanography of the Indonesian seas and their throughflow. Oceanography, 18(4):14-27.

http://dx.doi.org/10.5670/oceanog.2005.01

Gradstein, F.M., Ogg, J.G., Schmitz, M.D., and Ogg, G.M. (Eds.), 2012. The Geological Time Scale 2012: Amsterdam (Elsevier).

Greenstein, B.J., and Pandolfi, J.M., 2008. Escaping the heat: range shifts of reef coral taxa in coastal Western Australia. Global Change Biology, 14(3):513-528. http://dx.doi.org/10.1111/j.1365-2486.2007.01506.x

Greenwood, D.R., Herold, N., Huber, M., Müller, R.D., and Seton, M., 2012. Early to middle Miocene monsoon climate in Australia: reply. Geology, 40(6):e274. http://dx.doi.org/10.1130/G33384Y.1

Gurnis, M., 1990. Bounds on global dynamic topography from Phanerozoic flooding of continental platforms. Nature, 344(6268):754-756. http://dx.doi.org/10.1038/344754a0

Gurnis, M., 1993. Phanerozoic marine inundation of continents driven by dynamic topography above subducting slabs. Nature, 364(6438):589-593. http://dx.doi.org/10.1038/364589a0

Gurnis, M., Müller, R.D., and Moresi, L., 1998. Cretaceous vertical motion of Australia and the Australian-Antarctic Discordance. Science, 279(5356):1499-1504. http://dx.doi.org/10.1126/science.279.5356.1499

Hall, R., 2009. Southeast Asia's changing palaeogeography. Blumea-Biodiversity, Evolution and Biogeography of Plants, 54(1-3):148-161. http://dx.doi.org/10.3767/000651909X475941

Haq, B.U., and Al-Qahtani, A.M., 2005. Phanerozoic cycles of sea-level change on the Arabian platform. GeoArabia, 10(2):127-160. http://www.gulfpetrolink.net/mepr/dwnld/Haq-and-Al-Qahtani2005/Haq_and_Qahtani_layout.pdf

Haq, B.U., Hardenbol, J., and Vail, P.R., 1987. Chronology of fluctuating sea levels since the Triassic. Science, 235(4793):1156-1167. http://dx.doi.org/10.1126/science.235.4793.1156

Heine, C., and Müller, R.D., 2005. Late Jurassic rifting along the Australian North West shelf: margin geometry and spreading ridge configuration.
Australian Journal of Earth Sciences, 52(1):27-39.

http://dx.doi.org/10.1080/08120090500100077

Heine, C., Müller, R.D., Steinberger, B., and DiCaprio, L., 2010. Integrating deep Earth dynamics in paleogeographic reconstructions of Australia. Tectonophysics, 483(1-2):135-150. http://dx.doi.org/10.1016/j.tecto.2009.08.028

Herold, N., Huber, M., Greenwood, D.R., Müller, R.D., and Seton, M., 2011. Early to middle Miocene monsoon climate in Australia. Geology, 39(1):36. http://dx.doi.org/10.1130/G31208.1

Hesse, P.P., Magee, J.W., and van der Kaars, S., 2004. Late Quaternary climates of the Australian arid zone: a review. Quaternary International, 118119:87-102. http://dx.doi.org/10.1016/S1040-6182(03)00132-0

Holbourn, A., Kuhnt, W., Kawamura, H., Jian, Z., Grootes, P., Erlenkeuser, H., and $\mathrm{Xu}, \mathrm{J}$. , 2005. Orbitally paced paleoproductivity variations in the Timor Sea and Indonesian Throughflow variability during the last 460 kyr. Paleoceanography, 20(3):PA3002. http://dx.doi.org/10.1029/2004PA001094

Huang, Y.-S., Lee, T.-Q., and Hsu, S.-K., 2011. Milankovitch-scale environmental variation in the Banda Sea over the past $820 \mathrm{ka}$ : fluctuation of the Indonesian Throughflow intensity. Journal of Asian Earth Sciences, 40(6):1180-1188. http://dx.doi.org/10.1016/j.jseaes.2010.08.011

Hull, J.N.F., and Griffiths, C.M., 2002. Sequence stratigraphic evolution of the Albian to recent section of the Dampier Sub-basin, North West shelf, Australia. In Keep, M., and Moss, S.J. (Eds.), The Sedimentary Basins of Western Australia (Volume 3): Perth, Australia (Petroleum Exploration Society of Australia), 617-639.

Isern, A.R., Langford, R.P., Truswell, E.M., and Wilford, G.E., 1995. Cainozoic. In Langford, R.P., Wilford, G.E., Truswell, E.M., and Isern, A.R. (Eds.), Paleogeographic Atlas of Australia (Volume 10): Canberra ACT, Australia (Australian Geological Survey Organization).

http://www.ga.gov.au/metadata-gateway/meta-

data/record/gcat_a05f7892-b531-7506-e044-00144fdd4fa6

James, N.P., and Bone, Y., 1991. Origin of a cool-water, Oligo-Miocene deep shelf limestone, Eucla platform, southern Australia. Sedimentology, 38(2):323-341. http://dx.doi.org/10.1111/j.1365-3091.1991.tb01263.x

James, N.P., Bone, Y., Kyser, T.K., Dix, G.R., and Collins, L.B., 2004. The importance of changing oceanography in controlling late Quaternary carbonate sedimentation on a high-energy, tropical, oceanic ramp: northwestern Australia. Sedimentology, 51(6):1179-1205. http://dx.doi.org/10.1111/j.1365-3091.2004.00666.x

James, N.P., Collins, L.B., Bone, Y., and Hallock, P., 1999. Subtropical carbonates in a temperate realm; modern sediments on the Southwest Australian shelf. Journal of Sedimentary Research, 69(6):1297-1321. http://dx.doi.org/10.2110/jsr.69.1297

Jian, Z., Yu, Y., Li, B., Wang, J., Zhang, X., and Zhou, Z., 2006. Phased evolution of the south-north hydrographic gradient in the South China Sea since the middle Miocene. Palaeogeography, Palaeoclimatology, Palaeoecology, 230(3-4):251-263. http://dx.doi.org/10.1016/j.palaeo.2005.07.018

Jones, H.A., 1973. Marine Geology of the Northwest Australian Continental Shelf. Bureau of Mineral Resources, Geology and Geophysics, Canberra, Australia (Australian Government Publishing Service), 136. http://www.ga.gov.au/corporate_data/104/Bull_136.pdf

Karas, C., Nürnberg, D., Gupta, A.K., Tiedemann, R., Mohan, K., and Bickert, T., 2009. Mid-Pliocene climate change amplified by a switch in Indonesian subsurface throughflow. Nature Geoscience, 2(6):434-438. http://dx.doi.org/10.1038/ngeo520

Karas, C., Nürnberg, D., Tiedemann, R., and Garbe-Schönberg, D., 2011. Pliocene Indonesian Throughflow and Leeuwin Current dynamics: implications for Indian Ocean polar heat flux. Paleoceanography, 26(2):PA2217. http://dx.doi.org/10.1029/2010PA001949

Kawamura, H., Holbourn, A., and Kuhnt, W., 2006. Climate variability and land-ocean interactions in the Indo Pacific Warm Pool: a 460-ka palynological and organic geochemical record from the Timor Sea. Marine Micropaleontology, 59(1):1-14. http://dx.doi.org/10.1016/j.marmicro.2005.09.001

Kendrick, G.W., Wyrwoll, K.-H., and Szabo, B.J., 1991. Pliocene-Pleistocene coastal events and history along the western margin of Australia. Quater- 
nary Science Reviews, 10(5):419-439.

http://dx.doi.org/10.1016/0277-3791(91)90005-F

Kennard, J.M., Deighton, I., Ryan, D., Edwards, D.S., and Boreham, C.J., 2003. Subsidence and thermal history modelling: new insights into hydrocarbon expulsion from multiple petroleum systems in the Browse Basin. In Ellis, G.K., Baillie, P.W., and Munson, T.J. (Eds.), Proceedings of the Timor Sea Symposium: Northern Territory Geological Survey-Special Publication, 1:411-435.

Kennett, J.P., Keller, G., and Srinivasan, M.S., 1985. Miocene planktonic foraminiferal biogeography and paleoceanographic development of the IndoPacific region. In Kennett, J.P. (Ed.), The Miocene Ocean: Paleoceanography and Biogeography. Memoir-Geological Society of America, 163:197-236. http://dx.doi.org/10.1130/MEM163-p197

Kershaw, A.P., van der Kaars, S., and Moss, P.T., 2003. Late Quaternary Milankovitch-scale climatic change and variability and its impact on monsoonal Australasia. Marine Geology, 201(1-3):81-95. http://dx.doi.org/10.1016/S0025-3227(03)00210-X

Kominz, M.A., Browning, J.V., Miller, K.G., Sugarman, P.J., Misintseva, S., and Scotese, C.R., 2008. Late Cretaceous to Miocene sea-level estimates from the New Jersey and Delaware coastal plain coreholes: an error analysis. Basin Research, 20(2):211-226. http://dx.doi.org/10.1111/j.1365-2117.2008.00354.x

Kuhnt, W., Holbourn, A., Hall, R., Zuvela, M., and Käse, R., 2004. Neogene history of the Indonesian Throughflow. In Clift, P., Wang, P., Kuhnt, W., and Hayes, D. (Eds.), Continent-Ocean Interactions within East Asian Marginal Seas. Geophysical Monograph, 149:299-320. http://dx.doi.org/10.1029/149GM16

Lee, T.-Y., and Lawver, L.A., 1995. Cenozoic plate reconstruction of Southeast Asia. Tectonophysics, 251(1-4):85-138. http://dx.doi.org/10.1016/0040-1951(95)00023-2

Li, Q., James, N.P., Bone, Y., and McGowran, B., 1999. Palaeoceanographic significance of recent foraminiferal biofacies on the southern shelf of Western Australia: a preliminary study. Palaeogeography, Palaeoclimatology, Palaeoecology, 147(1-2):101-120. http://dx.doi.org/10.1016/S0031-0182(98)00150-3

Lisiecki, L.E., and Raymo, M.E., 2005. A Pliocene-Pleistocene stack of 57 globally distributed benthic $\delta^{18} \mathrm{O}$ records. Paleoceanography, 20(1):PA1003. http://dx.doi.org/10.1029/2004PA001071

Lithgow Bertelloni, C., and Gurnis, B., 1997. Cenozoic subsidence and uplift of continents from time-varying dynamic topography. Geology, 25(8):735-738. http://dx.doi.org/10.1130/0091-

7613(1997)025<0735:CSAUOC >2.3.CO;2

Liu, C., Fulthorpe, C.S., Austin, J.A., Jr., and Sanchez, C.M., 2011. Geomorphologic indicators of sea level and lowstand paleo-shelf exposure on early-middle Miocene sequence boundaries. Marine Geology, 208(14):179-191. http://dx.doi.org/10.1016/j.margeo.2010.12.010

Longley, I.M., Buessenschuett, C., Clydsdale, L., Cubitt, C.J., Davis, R.C., Johnson, M.K., Marshall, N.M., Murray, A.P., Somerville, R., Spry, T.B., and Thompson, N.B., 2002. The North West shelf of Australia-a Woodside perspective. In Keep, M., and Moss, S.J. (Eds.), The Sedimentary Basins of Western Australia (Volume 3): Perth, Australia (Petroleum Exploration Society of Australia), 27-88.

Magee, J.W., Miller, G.H., Spooner, N.A., and Questiaux, D., 2004. Continuous 150 k.y. monsoon record from Lake Eyre, Australia: insolation-forcing implications and unexpected Holocene failure. Geology, 32(10):885-888. http://dx.doi.org/10.1130/G20672.1

Malcolm, R.J., Pott, M.C., and Delfos, E., 1991. A new tectono-stratigraphic synthesis of the North West Cape area. APPEA Journal, 31(1):154-176.

McClymont, E.L., Sosdian, S.M., Rosell-Melé, A., and Rosenthal, Y., 2013. Pleistocene sea-surface temperature evolution: early cooling, delayed glacial intensification, and implications for the mid-Pleistocene climate transition. Earth-Science Review, 123:173-193. http://dx.doi.org/10.1016/j.earscirev.2013.04.006

McGowran, B., Li, Q., Cann, J., Padley, D., McKirdy, D.M., and Shafik, S., 1997. Biogeographic impact of the Leeuwin Current in southern Australia since the late middle Eocene. Palaeogeography, Palaeoclimatology, Palaeoecol- ogy, 136(1-4):19-40.

http://dx.doi.org/10.1016/S0031-0182(97)00073-4

McLaren, S., and Wallace, M.W., 2010. Plio-Pleistocene climate change and the onset of aridity in southeastern Australia. Global and Planetary Change, 71(1-2):55-72. http://dx.doi.org/10.1016/j.gloplacha.2009.12.007

McLaren, S., Wallace, M.W., Gallagher, S.J., Miranda, J.A., Holdgate, G.R., Gow, L.J., Snowball, I., and Sandgren, P., 2011. Palaeogeographic, climatic and tectonic change in southeastern Australia: the late Neogene evolution of the Murray Basin. Quaternary Science Reviews, 30(9-10):1086-1111. http://dx.doi.org/10.1016/j.quascirev.2010.12.016

McLaren, S., Wallace, M.W., Gallagher, S.J., Wagstaff, B.E., and Tosolini, A.M.P., 2014. The development of a climate: an arid continent with wet fringes. In Prins, H.H.T., and Gordon, I.J. (Eds.), Invasion Biology and Ecosystem Theory: Insights from a Continent in Transformation: Cambridge, United Kingdom (Cambridge University Press), 256-280.

McLaren, S., Wallace, M.W., and Reynolds, T., 2012. The late Pleistocene evolution of palaeo megalake Bungunnia, southeastern Australia: a sedimentary record of fluctuating lake dynamics, climate change and the formation of the modern Murray River. Palaeogeography, Palaeoclimatology, Palaeoecology, 317-318:114-127.

http://dx.doi.org/10.1016/j.palaeo.2011.12.020

McMinn, A., 1992. Neogene dinoflagellate distribution in the eastern Indian Ocean from Leg 123, Site 765. In Gradstein, F.M., Ludden, J.N., et al., Proceedings of the Ocean Drilling Program, Scientific Results, 123: College Station, TX (Ocean Drilling Program), 429-441.

http://dx.doi.org/10.2973/odp.proc.sr.123.120.1992

McMinn, A., 2002. Marine Quaternary dinoflagellate cysts of Australia, Papua-New Guinea, New Zealand and the Southern Ocean: a review. Alcheringa, 26(4):519-530. http://dx.doi.org/10.1080/03115510208619541

Metcalfe, I., 1988. Origin and assembly of south-east Asian continental terranes. In Audley-Charles, M.G., and Hallam, A. (Eds.), Gondwana and Tethys. Geological Society Special Publication, 37:101-118. http://dx.doi.org/10.1144/GSL.SP.1988.037.01.08

Miller, K.G., Kominz, M.A., Browning, J.V., Wright, J.D., Mountain, G.S., Katz, M.E., Sugarman, P.J., Cramer, B.S., Christie-Blick, N., and Pekar, S.F., 2005. The Phanerozoic record of global sea-level change. Science, 310(5752):1293-1298. http://dx.doi.org/10.1126/science.1116412

Moss, G.D., Cathro, D.L., and Austin, J.A., Jr., 2004. Sequence biostratigraphy of prograding clinoforms, Northern Carnarvon Basin, Western Australia: a proxy for variations in Oligocene to Pliocene global sea level? Palaios, 19(3):206-226. http://dx.doi.org/10.1669/08831351(2004)019<0206:SBOPCN>2.0.CO;2

Moucha, R., Forte, A.M., Mitrovica, J.X., Rowley, D.B., Quéré, S., Simmons, N.A., and Grand, S.P., 2008. Dynamic topography and long-term sea-level variations: there is no such thing as a stable continental platform. Earth and Planetary Science Letters, 271(1-4):101-108. http://dx.doi.org/10.1016/j.epsl.2008.03.056

Müller, R.D., Lim, V.S.L., and Isern, A.R., 2000. Late Tertiary tectonic subsidence on the northeast Australian passive margin: response to dynamic topography? Marine Geology, 162(2-4):337-352. http://dx.doi.org/10.1016/S0025-3227(99)00089-4

Müller, R.D., Sdrolias, M., Gaina, C., and Roest, W.R., 2008a. Age, spreading rates, and spreading asymmetry of the world's ocean crust. Geochemistry, Geophysics., Geosystems, 9(4):Q04006. http://dx.doi.org/10.1029/2007GC001743

Müller, R.D., Sdrolias, M., Gaina, C., Steinberger, B., and Heine, C., 2008b. Long-term sea-level fluctuations driven by ocean basin dynamics. Science, 319(5868):1357-1362. http://dx.doi.org/10.1126/science.1151540

Oliver, P.M., Laver, R.J., Smith, K.L., and Bauer, A.M., 2014. Long-term persistence and vicariance within the Australian monsoonal tropics: the case of the giant cave and tree geckos (Pseudothecadactylus). Australian Journal of Zoology, 61(6):462-468. http://dx.doi.org/10.1071/ZO13080

Pattiaratchi, C., 2006. Surface and sub-surface circulation and water masses off Western Australia. Bulletin of the Australian Meteorological and Oceanographic Society, 19:95-104. 
Pearce, A., 2009. Introduction: some historical "milestones" in the Leeuwin Current, and the Leeuwin Current Symposium 2007. Journal of the Royal Society of Western Australia, 92(2):31-36.

Renema, W., 2007. Fauna development of larger benthic foraminifera in the Cenozoic of Southeast Asia. In Renema, W. (Ed.), Topics in Geobiology (Volume 29): Biogeography, Time, and Place: Distributions, Barriers, and Islands. Landman, N.H., and Jones, D.S. (Series Eds.): Dordrecht, The Netherlands (Springer), 179-215. http://dx.doi.org/10.1007/978-1-4020-6374-9_6

Richardson, A.N., and Blundell, D.J., 1996. Continental collision in the Banda arc. Geological Society Special Publication, 106(1):47-60. http://dx.doi.org/10.1144/GSL.SP.1996.106.01.05

Rohling, E.J., Foster, G.L., Grant, K.M., Marino, G., Roberts, A.P., Tamisiea, M.E., and Williams, F., 2014. Sea-level and deep-sea-temperature variability over the past 5.3 million years. Nature, 508(7497):477-482. http://dx.doi.org/10.1038/nature13230

Romine, K.K., Durrant, J.M., Cathro, D.L., and Bernardel, G., 1997. Petroleum play element prediction for the Cretaceous-Tertiary basin phase, Northern Carnarvon Basin. APPEA Journal, 37(1):315-338.

Rosleff-Soerensen, B., Reuning, L., Back, S., and Kukla, P., 2012. Seismic geomorphology and growth architecture of a Miocene barrier reef, Browse Basin, NW-Australia. Marine and Petroleum Geology, 29(1):233-254. http://dx.doi.org/10.1016/j.marpetgeo.2010.11.001

Russell, M., and Gurnis, M., 1994. The planform of epeirogeny: vertical motions of Australia during the Cretaceous. Basin Research, 6(2-3):6376. http://dx.doi.org/10.1111/j.1365-2117.1994.tb00076.x

Ryan, G.J., Bernadel, G., Kennard, J.M., Jones, A.T., Logan, G.A., and Rollet, N., 2009. A precursor extensive Miocene reef system to the Rowley Shoals reefs, WA: evidence for structural control of reef growth or natural hydrocarbon seepage? APPEA Journal, 49:337-363.

Sakai, S., and Jige, M., 2006. Characterization of magnetic particles and magnetostratigraphic dating of shallow-water carbonates in the Ryukyu Islands, northwestern Pacific. Island Arc, 15(4):468-475. http://dx.doi.org/10.1111/j.1440-1738.2006.00542.x

Sayers, J., Symonds, P.A., Direen, N.G., and Bernardel, G., 2001. Nature of the continent-ocean transition on the non-volcanic rifted margin of the central Great Australian Bight. In Wilson, R.C.L., Whitmarsh, R.B., Taylor, B., and Froitzheim, N. (Eds.), Non-volcanic Rifting of Continental Margins: A Comparison of Evidence from Land and Sea. Geological Society Special Publication, 187(1):51-76. http://dx.doi.org/10.1144/GSL.SP.2001.187.01.04

Sengor, A.M.C., 1987. Tectonics of the Tethysides: orogenic collage development in a collisional setting. Annual Review of Earth and Planetary Sciences, 15(1):213-244. http://dx.doi.org/10.1146/annurev.ea.15.050187.001241

Seton, M., Müller, R.D., Zahirovic, S., Gaina, C., Torsvik, T., Shephard, G., Talsma, A., Gurnis, M., Turner, M., Maus, S., and Chandler, M., 2012. Global continental and ocean basin reconstructions since 200 Ma. EarthScience Reviews, 113(3-4):212-270.

http://dx.doi.org/10.1016/j.earscirev.2012.03.002

Sinha, D.K., Singh, A.K., and Tiwari, M., 2006. Palaeoceanographic and palaeoclimatic history of ODP Site 763A (Exmouth Plateau), southeast Indian Ocean: 2.2 Ma record of planktic foraminifera. Current Science, 90(10):1363-1369.

Sleep, N.H., 1976. Platform subsidence mechanisms and "eustatic" sea-level changes. Tectonophysics, 36(1-3):45-56. http://dx.doi.org/10.1016/0040-1951(76)90005-6

Sniderman, J.M.K., Jordan G.J., and Cowling, R.M., 2013. Fossil evidence for a hyperdiverse sclerophyll flora under a non-Mediterranean-type climate. Proceedings of the National Academy of Sciences of the United States of America, 110(9):3423-3428.

http://dx.doi.org/10.1073/pnas.1216747110

Sniderman, J.M.K., Porch, N., and Kershaw, A.P., 2009. Quantitative reconstruction of early Pleistocene climate in southeastern Australia and implications for atmospheric circulation. Quaternary Science Reviews, 28(2728):3185-3196. http://dx.doi.org/10.1016/j.quascirev.2009.08.006
Spasojević, S., Liu, L., Gurnis, M., and Müller, R.D., 2008. The case for dynamic subsidence of the U.S. East Coast since the Eocene. Geophysical Research Letters, 35(8):L08305.

http://dx.doi.org/10.1029/2008GL033511

Spooner, M.I., Barrows, T.T., De Deckker, P., and Paterne, M., 2005. Palaeoceanography of the Banda Sea, and late Pleistocene initiation of the northwest monsoon. Global and Planetary Change, 49(1-2):28-46. http://dx.doi.org/10.1016/j.gloplacha.2005.05.002

Spooner, M.I., De Deckker, P., Barrows, T.T., and Fifield, L.K., 2011. The behaviour of the Leeuwin Current offshore NW Australia during the last five glacial-interglacial cycles. Global and Planetary Change, 75(34):119-132. http://dx.doi.org/10.1016/j.gloplacha.2010.10.015

Srinivasan, M.S., and Sinha, D.K., 1998. Early Pliocene closing of the Indonesian Seaway: evidence from north-east Indian Ocean and tropical Pacific deep sea cores. Journal of Asian Earth Sciences, 16(1):29-44. http://dx.doi.org/10.1016/S0743-9547(97)00041-X

Struckmeyer, H.I.M., Blevin, J.E., Sayers, J., Totterdell, J.M., Baxter, K., and Cathro, D.L., 1998. Structural evolution of the Browse Basin, North West shelf: new concepts from deep-seismic data. In Purcell, P.G., and Purcell, R.R. (Eds.), The Sedimentary Basins of Western Australia (Vol. 2): Perth (Petroleum Exploration Society of Australia), 345-368.

Sturman, A.P., and Tapper, N.J., 2005. The Weather and Climate of Australia and New Zealand: Melbourne (Oxford University Press).

Stuut, J.-B.W., Temmesfield, F., and De Deckker, P., 2014. A 550 ka record of aeolian activity near North West Cape, Australia: inferences from grainsize distributions and bulk chemistry of SE Indian Ocean deep-sea sediments. Quaternary Science Reviews, 83:83-94. http://dx.doi.org/10.1016/j.quascirev.2013.11.003

Suppiah, R., 1992. The Australian summer monsoon: a review. Progress in Physical Geography, 16(3):283-318. http://dx.doi.org/10.1177/030913339201600302

Tomczak, M., and Godfrey, J.S., 1994. Regional Oceanography: An Introduction: New York (Pergamon Press).

Turney, C.S.M., Haberle, S., Fink, D., Kershaw, A.P., Barbetti, M., Barrows, T.T., Black, M., Cohen, T.J., Corrège, T., Hesse, P.P., Hua, Q., Johnston, R., Morgan, V., Moss, P., Nanson, G., van Ommen, T., Rule, S., Williams, N.J., Zhao, J.-X., D'Costa, D., Feng, Y.-X., Gagan, M., Mooney, S., and Xia, Q., 2006. Integration of ice-core, marine and terrestrial records for the Australian Last Glacial Maximum and Termination: a contribution from the OZ INTIMATE group. Journal of Quaternary Science, 21(7):751-761. http://dx.doi.org/10.1002/jqs.1073

van der Kaars, S., and De Deckker, P., 2002. A late Quaternary pollen record from deep-sea Core Fr10/95, GC17 offshore Cape Range Peninsula, northwestern Western Australia. Review of Palaeobotany and Palynology, 120(1-2):17-39. http://dx.doi.org/10.1016/S0034-6667(02)00075-1

van der Kaars, S., and De Deckker, P., 2003. Pollen distribution in marine surface sediments offshore Western Australia. Review of Palaeobotany and Palynology, 124(1-2):113-129. http://dx.doi.org/10.1016/S0034-6667(02)00250-6

van der Kaars, S., De Deckker, P., and Gingele, F.X., 2006. A 100,000-year record of annual and seasonal rainfall and temperature for northwestern Australia based on a pollen record obtained offshore. Journal of Quaternary Science, 21(8):879-889. http://dx.doi.org/10.1002/jqs.1010

Veevers, J.J. (Ed.), 2000. Billion-Year Earth History of Australia and Neighbours in Gondwanaland: Sydney (GEMOC Press, Macquarie University), 400 .

Veevers, J.J., Powell, C.M., and Roots, S.R., 1991. Review of seafloor spreading around Australia. I. Synthesis of the patterns of spreading. Australian Journal of Earth Sciences, 38(4):373-389. http://dx.doi.org/10.1080/08120099108727979

von Rad, U., Haq, B.U., et al., 1992. Proceedings of the Ocean Drilling Program, Scientific Results, 122: College Station, TX (Ocean Drilling Program). http://doi:10.2973/odp.proc.sr.122.1992

Wallace, M.W., Condilis, E., Powell, A., Redfearn, J., Auld, K., Wiltshire, M., Holdgate, G., and Gallagher, S., 2003. Geological controls on sonic velocity in the Cenozoic carbonates of the Northern Carnarvon Basin, North West shelf, Western Australia. APPEA Journal, 43(1):385-400. 
Wallace, M.W., Holdgate, G.R., Daniels, J., Gallagher, S.J., and Smith, A., 2002. Sonic velocity, submarine canyons, and burial diagenesis in OligoceneHolocene cool-water carbonates, Gippsland Basin, southeast Australia. AAPG Bulletin, 86(9):1593-1607.

http://dx.doi.org/10.1306/61EEDD14-173E-11D78645000102C1865D

Wells, P.E., and Wells, G.M., 1994. Large-scale reorganization of ocean currents offshore Western Australia during the late Quaternary. Marine Micropaleontology, 24(2):157-186. http://dx.doi.org/10.1016/0377-8398(94)90020-5

Williams, M., Cook, E., van der Kaars, S., Barrows, T., Shulmeister, J., and Kershaw, P., 2009. Glacial and deglacial climatic patterns in Australia and surrounding regions from 35,000 to 10,000 years ago reconstructed from terrestrial and near-shore proxy data. Quaternary Science Reviews, 28(23-24):2398-2419. http://dx.doi.org/10.1016/j.quascirev.2009.04.020

Wyrwoll, K.-H., Greenstein, B.J., Kendrick, G.W., and Chen, G.S., 2009. The palaeoceanography of the Leeuwin Current: implications for a future world. Journal of the Royal Society of Western Australia, 92(2):37-51. http://www.rswa.org.au/publications/Journal/92(2)/ROY SOC 92.2 LEEUWIN 37-51.pdf

Wyrwoll, K.-H., Hopwood, J.M., and Chen, G., 2012. Orbital time-scale circulation controls of the Australian summer monsoon: a possible role for mid-latitude Southern Hemisphere forcing? Quaternary Science Reviews, 35:23-28. http://dx.doi.org/10.1016/j.quascirev.2012.01.003

Wyrwoll, K.-H., Liu, Z., Chen, G., Kutzbach, J.E., and Liu, X., 2007. Sensitivity of the Australian summer monsoon to tilt and precession forcing. Quaternary Science Reviews, 26(25-28):3043-3057. http://dx.doi.org/10.1016/j.quascirev.2007.06.026

Wyrwoll, K.-H., and Miller, G.H., 2001. Initiation of the Australian summer monsoon 14,000 years ago. Quaternary International, 83-85:119-128. http://dx.doi.org/10.1016/S1040-6182(01)00034-9

Xu, J., Kuhnt, W., Holbourn, A., Andersen, N., and Bartoli, G., 2006. Changes in the vertical profile of the Indonesian Throughflow during Termination II: evidence from the Timor Sea. Paleoceanography, 21(4):PA4202. http://dx.doi.org/10.1029/2006PA001278 